\title{
TAXA DE CÂMBIO E DETERMINANTES DA BALANÇA COMERCIAL DE PRODUTOS AGRÍCOLAS E AGROINDUSTRIAIS \\ DO BRASIL: 1961 A 1995
}

\section{CLÓVIS OLIVEIRA DE ALMEIDA}

Engenheiro Agrônomo

Orientador: Prof. Dr. Carlos José Caetano Bacha

Tese apresentada à Escola Superior de Agricultura "Luiz de Queiroz", Universidade de São Paulo, para obtenção do título de Doutor em Ciências, Área de Concentração: Economia Aplicada.

PIRACICABA

Estado de São Paulo - Brasil

Janeiro - 1998 
Dados Internacionais de Catalogação na Publicação (CIP) DIVISÃO DE BIBLIOTECA E DOCUMENTACÃ̃O - Campus "Luiz de Queiroz"/USP

\section{Almeida, Clóvis Oliveira de}

Taxa de câmbio e determinantes da balança comercial de produtos agricolas e agroindustriais do Brasil : 1961 a 1995 / Clóvis Oliveira de Almeida. - Piracicaba, 1998.

$105 \mathrm{p}$.

Tese (doutorado) - Escola Superior de Agricultura Luiz de Queiroz, 1998. Bibliografia.

1. Balança comercial (Brasil) 2. Câmbio (taxa) 3. Econometria 4. Produto agricola 1. Título

CDD 338.17

332.45

382.17 


\section{TAXA DE CÂMBIO E DETERMINANTES DA BALANÇA COMERCIAL DE PRODUTOS AGRÍCOLAS E AGROINDUSTRIAIS DO BRASIL: 1961 A 1995}

ClóVIS OliveIRA DE ALMEIDA

Aprovada em: 09.03.1998

Comissão julgadora:

Prof. Dr. CARLOS JOSÉ CAETANO BACHA ESALQ/USP

Prof. Dr. RODOLFO HOFFMANN ESALQ/USP

Prof. Dr. GERALDO SANTA'ANA DE CAMARGO BARROS ESALQ/USP

Prof. Dr. PAULO PICCHETTI

FEA/USP

Prof. Dr. JOSÉ MARIA ALVES DA SILVA

UFV

CgBachon

Prof. CARLOS JOSÉ CAETANO BACHA Orientador 


\section{OFEREÇO}

Ao meu primo e amigo Antônio Raimundo Ferreira Alves e ao professor Amilcar Baiardi.

\section{DEDICO}

Aos meus pais Armênio e Eunice, por terem me proporcionado, indiretamente, a oportunidade que não tiveram. Aos meus irmãos Jorge, Maria Aparecida, Armenilton, Agnaldo e José Augusto, pelo apoio e incentivo demonstrados e, em especial, a Maria Gomes dos Santos, pela compreensão e companheirismo em boa parte de minha vida. 


\section{AGRADECIMENTOS}

É com muita satisfação que agradeço ao professor Carlos José Caetano Bacha, pela inesquecível e dedicada orientação durante a execução deste trabalho.

Ao professor Rodolfo Hoffmann, a quem freqüentemente recorri para elucidar dúvidas e receber preciosas sugestões, meus sinceros agradecimentos.

Aos professores Geraldo Sant'Ana de Camargo Barros, Paulo Picchetti e José Maria Alves da Silva, pelas valiosas críticas e sugestões.

Ao professor Antônio Álvaro Zini Jr, com gratidão pelos conhecimentos transmitidos na área de Economia Internacional.

Ao professor Paulo Fernando Cidade de Araújo, pela atenta leitura do texto e sugestões apresentadas.

Ao professor Bent Nielsen, pela atenção dispensada e sugestões apresentadas a parte metodológica do trabalho.

À acadêmica Clea Santos Rahal, pelo auxílio no levantamento e tabulação dos dados e, ao doutorando Carlos Augusto Pereira Filho, pela indicação da fonte básica de dados.

Aos professores do Departamento de Economia e Sociologia Rural da ESALQ/USP, pelos ensinamentos transmitidos.

Ao Conselho Nacional de Desenvolvimento Científico e Tecnológico (CNPq) e à Coordenação de Aperfeiçoamento de Pessoal de Nível Superior (CAPES), que, em distintos períodos, contribuíram financeiramente para a realização deste trabalho.

À Empresa Brasileira de Pesquisa Agropecuária (Embrapa), pelo período de liberação para realização do Curso.

Aos funcionários do Departamento de Economia e Sociologia Rural, pela dedicação, profissionalismo e amizade.

Aos colegas de curso, pela convivência e experiências vividas. 


\section{SUMÁRIO}

página

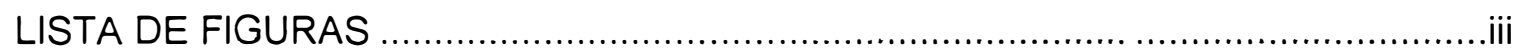

LISTA DE TABELAS ...................................................................................

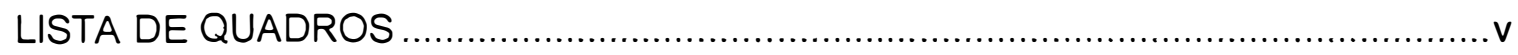

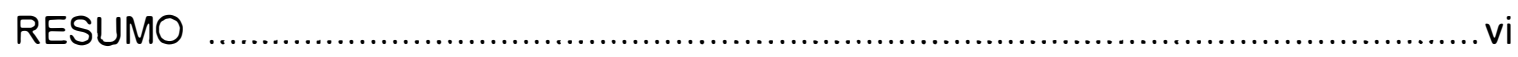

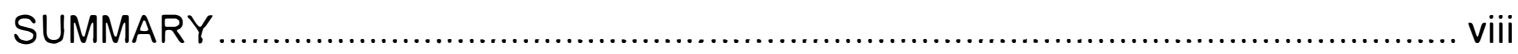

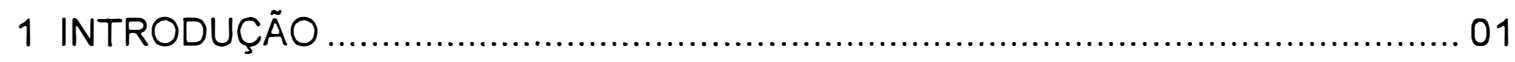

2 EVOLUÇÃO DA POLÍTICA CAMBIAL E DA TAXA DE CÂMBIO NO BRASIL

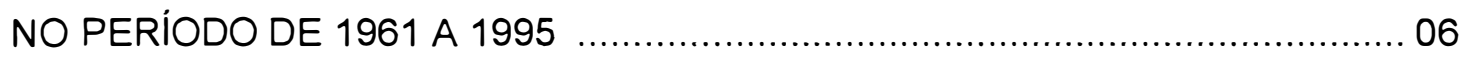

2.1 Distinção entre taxa de câmbio real e taxa de câmbio efetiva real ..................... 06

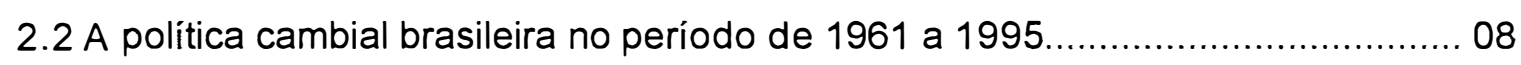

2.3 Evolução da taxa de câmbio efetiva real e da taxa de câmbio real .................... 16

3 TAXA DE CÂMBIO E TRANSAÇÕES EXTERNAS COM MERCADORIAS NO

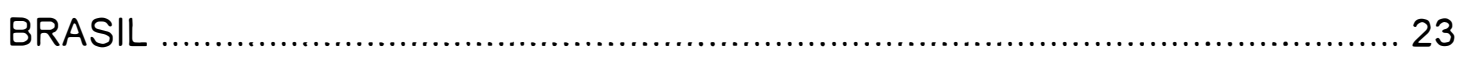

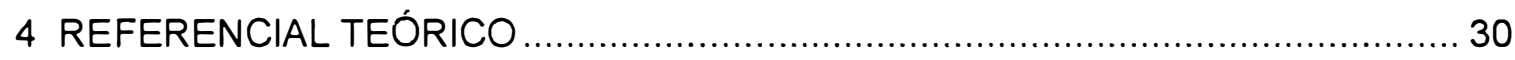

4.1 Abordagens de ajustamento da balança comercial ..................................... 30

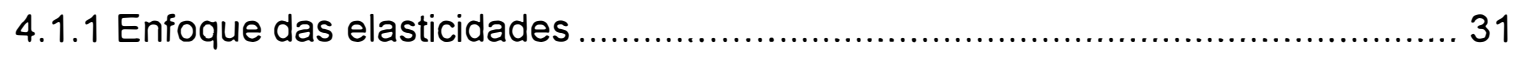

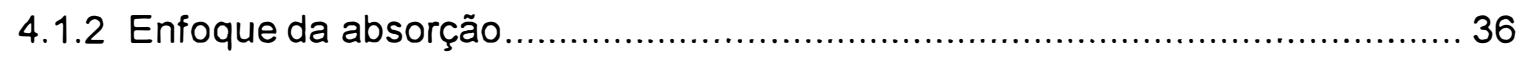

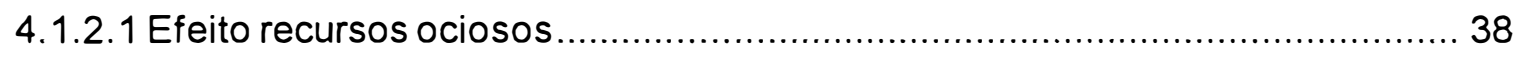

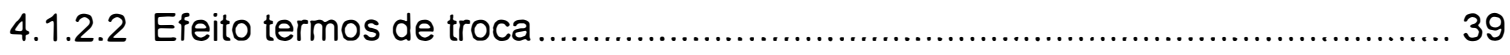

4.1.2.3 Efeito direto de uma desvalorização cambial .......................................... 40

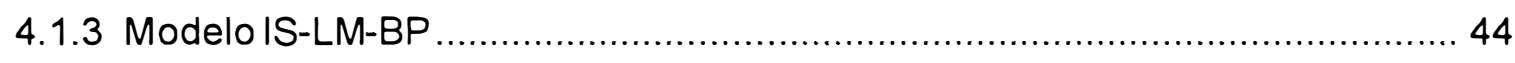

4.1.4 Comparação entre a abordagem das elasticidades, a abordagem da absorção e o modelo IS-TB...................................................................... 48 
4.2 Equação básica do saldo da balança comercial ............................................ 49

4.2.1 Efeitos esperados de uma desvalorização cambial ...................................... 50

4.2.2 Efeitos esperados de uma variação nos termos de troca ............................... 52

4.2.3 Efeitos esperados de uma variação no nível de renda doméstica .................... 52

4.2.4 Efeitos esperados de uma variação no nível de renda externa ....................... 53

4.2.5 Efeitos esperados decorrentes de geadas sobre os cafezais do Brasil........... 53

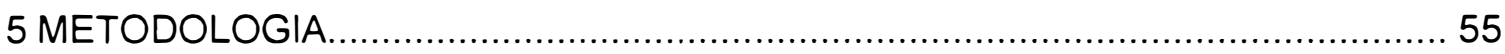

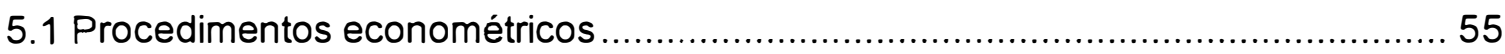

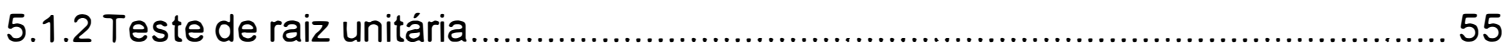

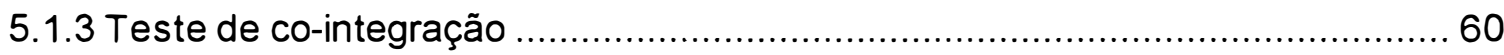

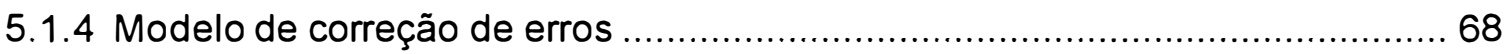

5.2 Definição das variáveis e fontes de dados......................................................69

5.3 Modelo econométrico a ser estimado.......................................................... 72

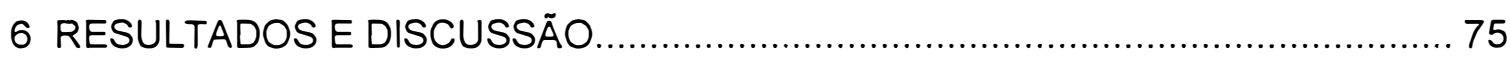

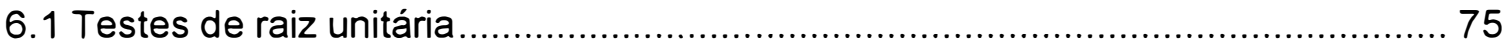

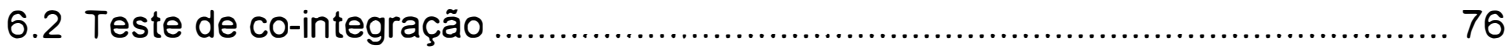

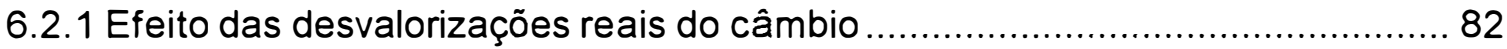

6.2.2 Efeito de uma elevação nos termos de troca................................................. 83

6.2.3 Efeito das variações no nível de renda interna ............................................ 84

6.2.4 Efeito das variações no nível de renda externa ........................................... 85

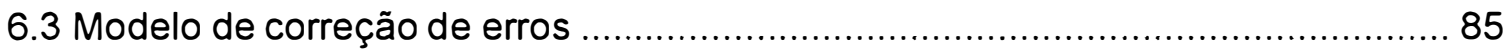



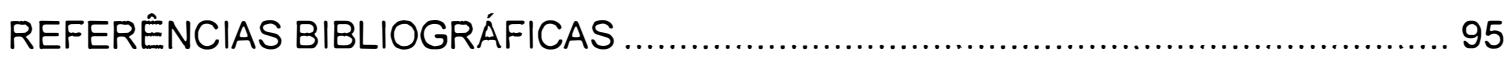

Apêndice - Derivação matemática de dois casos especiais da condição Marshall-Lerner. 


\section{LISTA DE FIGURAS}

página

Figura 1. Evolução dos saldos da balança comercial brasileira: total, agrícola total (excluindo fertilizantes e defensivos agrícolas) e não-agrícola no período de 1961 a 1995, em US\$ bilhões de 1995

Figura 2. Evolução da taxa de câmbio efetiva real do Brasil no periodo de 1961 a 1995

(diferentes indicadores) 


\section{LISTA DE TABELAS}

página

Tabela 1 Saldo comercial agrícola total (SAT); taxa de câmbio efetiva real (e-IPA); termos de troca $(\mathrm{TT})$; renda doméstica $(\mathrm{RB})$; renda externa $(\mathrm{RW})$; e, variável binária (D)

Tabela 2.Testes Dickey-Fuller Aumentado de raiz unitária:variável dependente em segunda diferença $\left(\Delta^{2} \ln y\right)$.

Tabela 3.Testes Dickey-Fuller Aumentado de raiz unitária: variável dependente em primeira diferença $(\Delta \ln y)$

Tabela 4. Testes para posto incompleto de co-integração do modelo selecionadado, usando dados para o período 1961 a 1995

Tabela 5. Estimativa da equação de correção de erros para o saldo da balança comercial agrícola total do Brasil [variável dependente $\Delta(\operatorname{lnSAT})$ ] - 1963 a 1995

Tabela 6. Estimativa da equação de correção de erros, versão parcimoniosa, para o saldo da balança comercial agrícola total do Brasil [variável dependente $\Delta(\operatorname{lnSAT})$ ] 


\section{LISTA DE QUADROS}

página

Quadro 1. Taxa de câmbio real do Brasil (diferentes indicadores) e estimativas das desvalorizações e valorizações reais do câmbio no periodo de 1985 a 1995 $($ Base $1985=100)$

Quadro 2. Taxa de câmbio real do Brasil (diferentes indicadores) e estimativas das desvalorizações e valorizações reais do câmbio no período de 1988 a 1995 (Base $1988=100)$

Quadro 3. Relações, mais prováveis, entre o saldo da balança comercial e um conjunto de variáveis, segundo a abordagem das elasticidades, a abordagem da absorção e o modelo IS-TB para o caso de um "pais pequeno" frente ao mercado internacional.

Quadro 4. Seqüência para o teste de raiz unitária ADF utilizando o procedimento seqüencial de Perron.

Quadro 5. Vetor de co-integração, coeficientes de ajustamento e estatística t de student.

Quadro 6. Teste de exogeneidade fraca para o logaritmo das variáveis (e-IPA), (TT), (RB) e (RW) em relação aos parâmetros de longo prazo. 80

Quadro 7 Teste de significância para as variáveis incluidas no espaço de co-integração 81 


\title{
TAXA DE CÂMBIO E DETERMINANTES DA BALANÇA COMERCIAL DE PRODUTOS AGRÍCOLAS E AGROINDUSTRIAIS DO BRASIL: 1961 A 1995
}

\author{
Autor: CLÓVIS OLIVEIRA DE ALMEIDA \\ Orientador: Prof. CARLOS JOSÉ CAETANO BACHA
}

\section{RESUMO}

O presente trabalho examina os efeitos, a longo e curto prazos, das variações na taxa de câmbio e em outras variáveis macroeconômicas sobre o saldo da balança comercial de produtos agrícolas e agroindustriais do Brasil, que representam a maior fonte de superávits comerciais gerados no período analisado (1961 a 1995). Para tanto, a análise de co-integração e o mecanismo de correção de erros são utilizados.

Os estudos realizados até então analisam, com base em técnicas econométricas tradicionais, o efeito da taxa de câmbio sobre as transações externas com produtos específicos ou grupo de produtos agrícolas, mas não sobre o saldo comercial de produtos agrícolas e agroindustriais (também denominado de saldo comercial agrícola total)

O objetivo da política cambial é afetar o saldo total do comércio. A importância de se avaliar o impacto sobre as transações externas com um produto ou grupo de produtos diminui à medida que se tem conhecimento de que a direção da política cambial não muda em função de um ou outro produto, a menos que o mesmo detenha uma parcela dominante da geração de divisas do país

A curto prazo, as variáveis mais relevantes para "explicar" as variações diretas observadas no saldo da balança comercial agrícola total são (do ponto de vista estatístico): renda interna, defasada de um período; renda externa, no período corrente; termos de troca, com uma defasagem; e, o termo de correção de erros (os desvios em relação ao equilíbrio de longo prazo). A taxa de câmbio efetiva real, no período corrente, 
também apresenta efeito positivo sobre o saldo da balança agrícola total (coerente com o esperado), mas tal efeito não teve bom nível de significância estatística.

A longo prazo, as desvalorizações da moeda doméstica exercem maior efeito sobre a competitividade externa dos setores agrícola e agroindustrial (aqui entendida como a capacidade de os setores gerarem superávits comerciais) do que as demais variáveis consideradas: renda interna, renda externa e termos de troca.

Finalmente, os resultados da pesquisa revelam ainda que não se pode ignorar a expressiva contribuição dos setores agrícolas e agroindustriais ao processo de ajustamento da balança comercial do Brasil. Esses setores foram as maiores fontes de superávits comerciais gerados no período em análise, permitindo, em vários anos, compensar o déficit comercial com produtos não-agrícolas ou, pelo menos, diminuir seu grande impacto negativo sobre o saldo da balança comercial total do Brasil. 


\title{
EXCHANGE RATE AND TRADE BALANCE DETERMINANTS FOR AGRICULTURAL AND AGRO-INDUSTRIAL PRODUCTS IN BRAZU: 1961 - 1995
}

\author{
Author: CLÓVIS OLIVEIRA DE ALMEIDA \\ Adviser: Prof. CARLOS JOSÉ CAETANO BACHA
}

\section{SUMMARY}

The present paper examines the long and short term effects of variations in the exchange rate and other macroeconomic variables on the trade balance of agricultural and agro-industrial products in Brazil. These products represent the greatest source of trade surpluses generated during the period analysed (from 1961 to 1995). The relations among variables are estimated using cointegration and the mechanism of error-correction.

The studies carried out up until now, based on traditional econometric methods, analyse the effect of exchange rates on external transactions with specific products or group of agricultural products, but not on the trade balance of agricultural and agro-industrial products (also denominated the total agricultural trade balance).

The purpose of the exchange policy is to affect the total trade balance. The importance of evaluating the impact on foreign transactions with a product or group of products diminishes as one knows that the direction of the exchange policy does not change because of one or other product, unless it plays a dominant part in the generating the country's foreign exchange.

In the short run, the most relevant variables "explaining" the variations observed in the balance of the total agricultural trade balance are (from a statistical point of view): domestic income, lagged for a period; foreing income, in the current period; lagged terms of trade; and, the error-correction term (deviations in relation to long term equilibrium). The real effective exchange rate in the current period also shows a positive 
effect on the total agricultural trade balance (as was expected), but such effect did not have a good level of statistical significance.

In the long run, domestic currency devaluations had a greater effect on external competitivity of agricultural and agro-industrial sectors (here understood as being the capacity of the sectors generating trade surpluses) than the other variables considered (domestic income, foreign income and terms of trade).

Finally, the results of the research furthermore reveal that the expressive contribution of agricultural and agro-industrial sectors on the process of ajusting Brazil's trade balance cannot be ignored. These sectors where the greatest sources of trade surplusses generated in the period analysed, which for several years permitted compensating the trade deficit with non agricultural products, or at least, diminishing their great negative impact on Brazil's total trade balance. 


\section{INTRODUÇÃO}

Esta pesquisa examina as contribuições das variações reais da taxa de câmbio e de outras variáveis macroeconômicas ao processo de ajustamento da balança comercial de produtos agrícolas e agroindustriais do Brasil no período de 1961 a 1995.

O saldo da balança comercial é o resultado líquido das transações comerciais de mercadorias do país com o resto do mundo. Quando as exportações de bens do país excedem as importações, registra-se um saldo comercial positivo (superávit). Contrariamente, quando as importações de bens superam as exportações, o saldo é negativo (déficit).

As exportações brasileiras de mercadorias, durante o período de 1961 a 1995, passaram por diversas modificações em sua composição e em suas taxas anuais de crescimento. A tendência verificada tem sido de aumento da participação dos produtos processados e manufaturados, tanto em valor quanto em quantidade exportada. As décadas de setenta e oitenta são citadas, na literatura, como um dos períodos de maiores transformações ocorridas nas exportações do país, registrando-se alteração em sua composição e elevadas taxas de crescimento, principalmente de produtos industrializados (ver Homem de Melo \& Zockun, 1977; Neves, 1984; e, Bontempo, 1989). Os produtos da agricultura, processados e primários, participavam com $75 \%$ do valor total exportado em 1970, 50\% em 1980 e 34\% em 1989 (ver Homem de Melo \& Zockun, 1977, p. 29; e, Guimarães \& Oliveira, 1990, p. 40).

A mudança na composição das exportações brasileiras reflete, dentre outros fatores, o programa de substituição de importações que teve início na década de trinta e se esgotou nos primeiros anos da década de oitenta, além das políticas de promoção às exportações de produtos industrializados, na forma de incentivos fiscais e 
creditícios. Enquanto isso as exportações de produtos da agricultura foram desestimuladas através de barreiras tarifárias e não-tarifárias, como analisam vários autores ${ }^{1}$.

Na década de oitenta, conforme constatado por Pinheiro et al (1993), excetuando-se os incentivos creditícios do início da década, as exportações agrícolas continuaram sendo discriminadas nas políticas de promoção às exportações.

Homem de Melo \& Zockun (1977, p. 23) afirmaram que, entre os diversos instrumentos utilizados para incentivar as exportações, apenas as minidesvalorizações cambiais beneficiaram a agricultura, ao reduzir a variação da taxa de câmbio real. Não obstante a afirmação dos citados autores, não se pode ignorar que a política de crédito subsidiado também beneficiou o setor agrícola de produtos exportáveis. Mais recentemente, em 1996, o Governo isentou as exportações de produtos primários e semimanufaturados do pagamento do Imposto sobre Circulação de Mercadorias e Serviços (ICMS), o que deve estimular as exportações desses produtos.

Em que pese a agricultura não ter recebido os incentivos de promoção às exportações na mesma proporção que se verificou para os produtos industrializados, não se pode ignorar a substancial contribuição do setor agrícola, juntamente com o setor agroindustrial, ao processo de ajustamento do saldo da balança comercial brasileira.

Através da Figura 1 constata-se que, durante todo o período de 1961 a 1995, o saldo da balança comercial agrícola total (que engloba produtos agrícolas e agroindustriais, não considerando as transações com fertilizantes e defensivos agrícolas) sempre registrou superávits ${ }^{2}$. O mesmo não se observa para o saldo comercial de produtos não-agrícolas, que teve déficit de 1961 a 1983, voltando a apresentar déficit em 1995. Portanto, durante o período de 35 anos aqui analisado, os setores não-agrícolas, em conjunto, só conseguiram gerar saldo comercial positivo com o exterior no período de 1984 a 1994, o que corresponde a apenas 11 anos. Contudo, mesmo para esses anos,

\footnotetext{
1 Ver, por exemplo, Mendonça de Barros et al, 1975; Homem de Melo \& Zockun, 1977; Schuh, 1977; Pastore et al e Coes citados por Pinheiro et al, 1993.

${ }^{2}$ Embora o Brasil seja um importador líquido de fertilizantes e defensivos agrícolas, a inclusão das transações externas com esses produtos não altera a tendência do saldo da balança comercial agrícola total apresentada na Figura 1. Para mais detalhes ver Almeida \& Bacha (1997).
} 
os saldos gerados pela agricultura e pela agroindústria foram maiores do que os produzidos pelos demais setores da economia.

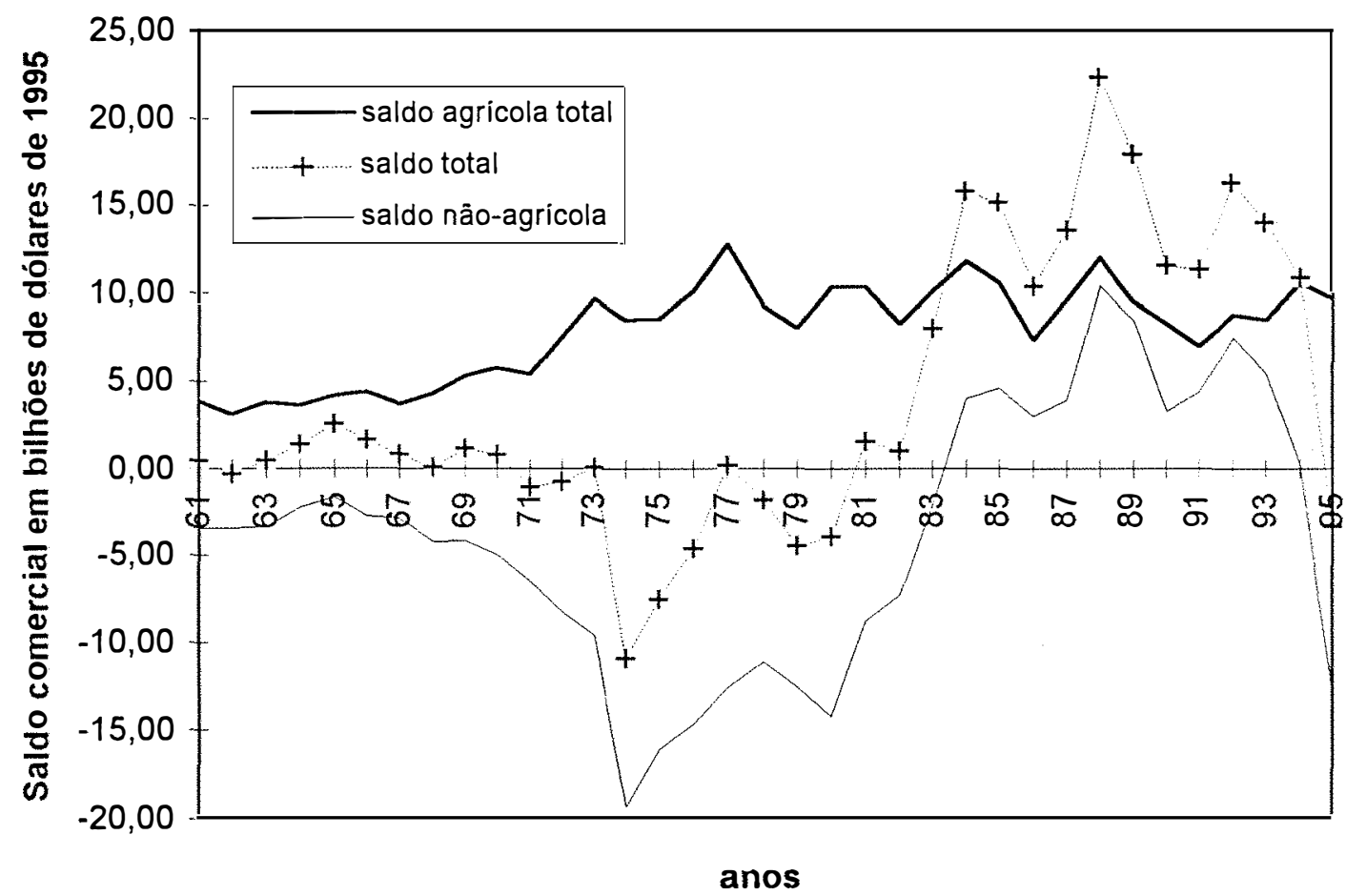

Nota: O saldo não-agrícola é a diferença entre o saldo total e o saldo agrícola.

Figura 1. Evolução dos saldos da balança comercial brasileira: total, agrícola total (não considerando as transações com fertilizantes e defensivos agrícolas) e nãoagrícola no período de 1961 a 1995, em US\$ bilhões de 1995.

Pode-se ainda notar na Figura 1 que, para o período considerado na presente pesquisa, os maiores déficits da balança comercial do país ocorreram nos anos de $1974,1975,1976,1979$ e $1980^{3}$, os quais foram 10,95, 7,55, 4,60, 4,50, e 3,92 bilhões de dólares (com poder de compra de 1995), respectivamente. Se se descontasse destes déficits a contribuição dos setores agrícola e agroindustrial ao processo de ajustamento da balança comercial, os déficits gerados pelos demais setores, naqueles anos, seriam de 19,36, 16,07, 14,65, 12,49 e 14,22 bilhões de dólares, respectivamente. Constata-se, por esses dados, que os déficits totais da balança comercial teriam sido $77 \%$

${ }^{3}$ Os anos de maiores déficits na balança comercial refletem as consequeências dos dois choques do petróleo que ocorreram na década de 70 . 
a $263 \%$ maiores naqueles anos se não tivessem ocorrido superávits na balança comercial de produtos agrícolas e agroindustriais

Não obstante a substancial contribuição dos produtos agrícolas e agroindustriais ao processo de ajustamento da balança comercial brasileira, não existe, ainda, um trabalho que examine quais variáveis afetam o saldo comercial agrícola total (entendido como sendo a soma do saldo comercial das transações com produtos agrícolas e agroindustriais)

Como constatado anteriormente, a desvalorização da taxa de câmbio foi considerada importante para o desempenho das exportações agrícolas. Por essa razão, o objetivo geral desta pesquisa é investigar quais as contribuições das variações reais da taxa de câmbio e de outras variáveis macroeconômicas ao processo de ajustamento da balança comercial de produtos agrícolas e agroindustriais do Brasil, considerados no agregado, por representarem, em conjunto, a maior fonte de superávits comerciais gerados no período em análise.

Entre os objetivos específicos da pesquisa estão: i) quantificar e analisar a evolução do saldo da balança comercial agrícola total; ii) avaliar os efeitos das políticas cambiais brasileiras sobre a evolução da taxa de câmbio real e efetiva real; iii) estimar um modelo econométrico que "explique" as variações a curto e longo prazos do saldo da balança comercial agrícola total; e, iv) avaliar a eficácia de uma política cambial em relação a uma política de renda em seus efeitos sobre o saldo da balança comercial agrícola total.

Esta pesquisa está organizada em cinco capítulos, incluindo esta Introdução. No capítulo 2, apresenta-se um levantamento histórico da política cambial brasileira, com o propósito de avaliar os seus possíveis impactos sobre a taxa de câmbio real e efetiva real. No capítulo 3, faz-se uma breve revisão da literatura sobre taxa de câmbio e transações externas com mercadorias no Brasil, procurando-se evidenciar que os objetivos acima especificados ainda não foram devidamente estudados no Brasil. No capítulo 4 está o referencial teórico da tese. No item 4.1 resumem-se três abordagens básicas de ajustamento da balança comercial (abordagem das elasticidades, abordagem da 
absorção e uma versão parcial do modelo IS-LM-BP, aqui denominada IS-TB), com especial atenção ao papel da taxa de câmbio no processo de ajustamento. A partir dessas abordagens e dos trabalhos empíricos, explicita-se a equação básica do saldo da balança comercial (item 4.2). O capítulo 5 propõe a utilização da análise de co-integração e o mecanismo de correção de erros como instrumentais econométricos para determinar os efeitos de curto e longo prazos da taxa de câmbio sobre o saldo comercial agrícola total. O capítulo 6 analisa os resultados da pesquisa. Finalmente, o capítulo 7 reúne as conclusões obtidas, destacando-se aquelas pertinentes às políticas cambial e de renda implementadas com o propósito de melhorar o saldo comercial do país. 


\section{EVOluÇão dA POLÍtica CAMbial E DA TAXA DE CÂMbio NO BRASIL NO PERÍODO DE 1961 A 1995}

Neste texto, conceitua-se taxa de câmbio como sendo o preço em moeda nacional de uma unidade monetária estrangeira tomada como referência. No Brasil é mais comum esse conceito, considerando-se a quantidade de reais (a moeda doméstica) trocada por uma unidade de dólar (a principal moeda estrangeira de referência no Brasil). Portanto, uma elevação na taxa de câmbio acusa uma desvalorização da moeda doméstica ${ }^{4}$, enquanto uma diminuição nessa taxa representa uma valorização da moeda nacional.

Para examinar a evolução da política cambial brasileira e seus efeitos sobre a taxa de câmbio é necessário, inicialmente, que se faça a distinção entre taxa de câmbio real e taxa de câmbio efetiva real.

\subsection{Distinção entre taxa de câmbio real e taxa de câmbio efetiva real}

Quando se fala em desvalorização cambial, é preciso distinguir entre uma desvalorização na taxa de câmbio real e uma desvalorização na taxa de câmbio efetiva real $^{5}$. A primeira refere-se a uma queda no valor da moeda doméstica em termos da moeda estrangeira de referência, usualmente o dólar americano ou a moeda do principal parceiro comercial. A segunda ocorre quando se usa uma cesta de moedas constituída geralmente pelas moedas dos principais parceiros comerciais do país para proceder às

\footnotetext{
${ }^{4}$ Na presente pesquisa os termos desvalorização da moeda doméstica, desvalorização da taxa de câmbio e desvalorização cambial são utilizados como sinônimos.

5 Para ver mais detalhes sobre esse assunto, consultar: Conjuntura Econômica (1976); Silva (1976); Schuh (1977): Homem de Melo \& Zockun (1977) e Pinheiro \& Horta (1992).
} 
desvalorizações. Desse modo, uma desvalorização na taxa de câmbio real não implica necessariamente uma desvalorização da taxa de câmbio efetiva real.

Se a regra das desvalorizações cambiais tem por base apenas a moeda de um único país, por exemplo o dólar americano, uma valorização do dólar frente a outras moedas fortes como as européias e a japonesa, tudo o mais permanecendo constante, produz o seguinte efeito nas relações comerciais do país que mantém sua moeda "ligada" ao dólar - se se leva em consideração o conceito de taxa efetiva: induz a uma valorização da moeda do país frente às moedas européias e japonesa, prejudicando as relações comerciais com esses países. Isso ocorre porque, tudo o mais permanecendo constante, os europeus e os japoneses teriam que pagar mais, em suas respectivas moedas, pela mesma quantidade importada de produtos do país que mantém a moeda doméstica atrelada ao dólar.

Adicionalmente, se a inflação do país que mantém sua moeda atrelada ao dólar for maior do que a inflação americana, pode-se ainda esperar uma valorização da moeda do país frente ao dólar americano, porém em menor proporção que a verificada em relação às demais moedas. Este último efeito pode ocorrer porque a desvalorização da moeda que tem por base o dólar americano não se dá de forma instantânea, existindo sempre uma descontinuidade entre as variações no valor da moeda americana no mercado internacional e o uso da regra para proceder à desvalorização.

Portanto, uma valorização do dólar frente às moedas dos parceiros comerciais do Brasil, ceteris paribus, aumenta a necessidade de o país recorrer às desvalorizações cambiais para preservar a competitividade de suas exportações ${ }^{6}$.

Outro efeito que pode decorrer da variação do poder de compra do dólar no mercado internacional, e que pode afetar a balança comercial de países exportadores e importadores de commodities, diz respeito à relação entre o valor da moeda norteamericana e o preço em dólares das commodities no mercado internacional. Vários trabalhos têm sugerido que quando o preço do dólar no mercado internacional sofre uma

\footnotetext{
${ }^{6}$ A defasagem cambial pode ser compensada por politicas compensatórias dirigidas ao setor exportador. Ademais, pelo menos temporariamente, a defasagem cambial também pode ser compensada por ganhos de produtividade no setor exportador e por uma eventual elevação nos termos de troca, em moeda externa, do pais que teve sua moeda valorizada.
} 
queda em relação às principais moedas fortes (isto é, há uma desvalorização do dólar no mercado internacional), os preços das commodities tendem a subir, via efeito-renda induzido pela desvalorização da moeda americana ${ }^{7}$. Isto é, o aumento em dólares na renda dos países que tiveram sua moeda valorizada frente à moeda americana induz um aumento de demanda por parte desses países no mercado internacional de commodities e, consequentemente, ocorre um aumento de preços em dólares dos produtos cujas demandas foram aumentadas.

A importância desta associação decorre do fato de que a percentagem de desvalorização requerida da moeda doméstica para manter a performance do setor exportador de commodities diminui quando a moeda americana se desvaloriza frente às demais moedas fortes no mercado internacional. Isto porque, tudo o mais permanecendo constante, a moeda nacional tende a se desvalorizar frente às demais moedas e os preços das commodities tendem a subir como conseqüência da queda no valor da moeda americana.

\subsection{A política cambial brasileira no período de 1961 a 1995}

Em março de 1961 foi feita uma reforma cambial no Brasil, passando o país a adotar um sistema de câmbio mais flexível que os vigentes anteriormente (de controles cambiais e câmbio múltiplo). No novo sistema, as exportações, exceto as de café, passaram a ser feitas usando o mercado de "câmbio livre". Posteriormente, também as exportações de café foram incluídas no "mercado livre". As mudanças introduzidas pelo Governo no mercado de câmbio visavam aumentar a unidade no mercado cambial.

De modo geral, até julho de 1968 a política cambial do Governo consistia em desvalorizar a moeda doméstica uma a duas vezes por ano, a intervalos de tempo relativamente longos e em grandes proporções (Baer, 1985, p. 205). Praticava-se, portanto, as maxidesvalorizações cambiais. Essa condução da política cambial mediante maxidesvalorizações da moeda doméstica introduzia vários problemas na economia brasileira (Zockun et al,1976; e Zini Jr., 1993). Primeiro, estimulava a especulação contra

\footnotetext{
Ver Homem de Melo \& Zockun (1977); Schuh (1977); Zini Jr. (1989) e Barros (1990).
} 
a moeda doméstica. Segundo, aumentava rapidamente os custos dos insumos importados logo após a maxidesvalorização cambial. Terceiro, mas não menos importante, aumentava o grau de incerteza quanto ao real valor da receita total obtida com as exportações, principalmente quando estas eram efetuadas com base em contratos de preços fixos.

De agosto de 1968 até fevereiro de 1990, o Brasil passou a praticar a política de minidesvalorizações cambiais baseadas na versão relativa da paridade do poder de compra da moeda (PPC). A versão relativa da PPC estabelece que as desvalorizações nominais do câmbio devem se igualar à diferença entre as inflações doméstica e internacional, tendo por objetivo manter uma certa paridade real fixa da moeda.

Mesmo durante o período em que a política de minidesvalorizações cambiais vigorou no Brasil, o Banco Central, em algumas ocasiões, fez uso da política de maxidesvalorizações cambiais. Em dezembro de 1979 foi feita uma maxidesvalorização nominal de $30 \%$ da moeda local em relação ao dólar, para compensar a eliminação dos subsídios fiscais (forçada pelo GATT) à exportação de manufaturados. De dezembro de 1979 a dezembro de 1980, a correção da taxa de câmbio foi pré-fixada em 40\%, visando reduzir o efeito inflacionário da maxidesvalorização praticada anteriormente. Outra maxidesvalorização cambial de $30 \%$ foi decretada em fevereiro de 1983 , com o objetivo de atingir um saldo de US\$ 6 bilhões na balança comercial, entre outras metas (Rios, 1987).

Zini Jr. (1993, p.118) atesta que as minidesvalorizações cambiais no Brasil seguiram a seguinte regra: “(..) até o primeiro semestre de 1983 (deixando de lado algumas mudanças de ênfase durante o período) era desvalorizar a moeda seguindo a diferença entre a inflação doméstica medida pelo Índice Geral de Preços (IGP) e a inflação internacional.(...). De meados de 1983 a 1985 a regra tornou-se mais simples: o cruzeiro foi vinculado ao dólar e as desvalorizações foram iguais à inflação doméstica (IGP). No segundo e terceiro trimestres de 1985 as desvalorizações excederam a taxa de inflação doméstica para compensar a apreciação do dólar". Segundo o mesmo autor, a política das minidesvalorizações cambiais tinha como objetivos evitar a especulação contra a moeda doméstica, estimulada pela política de maxidesvalorizações praticada 
anteriormente, bem como proteger a receita das exportações de uma possível deterioração.

Três elementos caracterizaram o período em que vigorou a política brasileira de minidesvalorizações cambiais, quais sejam: os pequenos intervalos entre as desvalorizações, o pequeno valor percentual em cada uma delas e sua suspensão em determinados momentos e retomada em seguida ${ }^{8}$. No período de 1968 a 1983 os intervalos entre as desvalorizações eram de três a dez dias. No período seguinte, de 1984 a fevereiro de 1986, o intervalo entre as desvalorizações foi diminuindo, chegando a ser diário e com valores percentuais pré-anunciados no final de 1985. Em 1986, a política foi suspensa após a implementação do Plano Cruzado, tendo o câmbio permanecido fixo de março a outubro. Os reflexos negativos do "congelamento" do câmbio sobre as exportações tornaram-se mais acentuados a partir do mês de setembro de 1986, quando as exportações registraram forte declínio. De novembro de 1986 a dezembro de 1988, o Governo Federal retomou a política de desvalorizações cambiais diárias, e as exportações voltaram a crescer. Em janeiro de 1989 entrou em vigor um novo plano de estabilização o Plano Verão. No mesmo mês, o câmbio foi desvalorizado em 16,38\%, sendo posteriormente mantido fixo até o mês de abril, quando as exportações voltaram a declinar. A partir de julho de 1989, a prática de desvalorizar o câmbio diariamente foi retomada, porém as desvalorizações implementadas não foram suficientes para recuperar a queda nas exportações.

As minidesvalorizações cambiais conseguiram reduzir a variância da taxa de câmbio real no período de agosto de 1968 a fevereiro de 1990. Não obstante, essa política não foi suficiente, em alguns anos, para evitar a deterioração da balança comercial provocada pela ocorrência dos choques externos na década de 70 (Zini Jr., 1993). Isto se deu em virtude de a moeda nacional ter ficado vinculada a uma paridade real fixa estabelecida antes dos choques externos, deixando de compensar as alterações que se seguiram nos termos de troca, conclui o autor mencionado acima.

\footnotetext{
${ }^{8} \mathrm{O}$ histórico sobre a política cambial brasileira que se segue neste parágrafo foi baseado em Horta, Piani \& Kume (1992), Zini Jr. (1993) e Pereira (1994, p. 22).
} 
A partir de março de 1990, o Brasil ingressou em um sistema de taxa de câmbio com "flutuação suja", que vigorou até junho de 1994. Neste sistema, o Banco Central podia, a qualquer momento, sempre que julgasse conveniente, intervir no mercado de divisas comprando ou vendendo moeda estrangeira, na tentativa de influenciar a taxa de câmbio. Não obstante, diferentemente do sistema anterior, o Banco Central não mais tinha a obrigação de fixar a taxa de câmbio.

No período de 1990 a 1991, as forças do mercado de câmbio trabalharam no sentido de fazer o câmbio variar de acordo com a inflação esperada para o mês (Zini Jr., 1993). Não obstante, continua o autor, por intervenção do Banco Central, de outubro a dezembro de 1990 ocorreram desvalorizações nominais maiores do que as esperadas pelo mercado. As intervenções do Banco Central tinham por objetivo reverter a tendência de queda nas exportações. Pela mesma razão, no final de setembro de 1991, o Banco Central voltou a intervir no mercado cambial de forma mais agressiva, tendo em um único dia forçado uma desvalorização cambial de 17\% (Zini Jr., 1993).

De janeiro de 1992 a março de 1994, as intervenções do Banco Central no mercado de câmbio visavam, mediante desvalorizações diárias, tornar a evolução da taxa de câmbio compatível com a evolução dos preços no Brasil, medida pelo Índice de Preços no Atacado (IPA) ${ }^{9}$. Não obstante, o diferencial entre as taxas de juros doméstica e internacional estimulava o ingresso de recursos externos e gerava um desequilíbrio entre oferta e demanda de divisas. Como resultado do forte ingresso de divisas, a taxa de câmbio real tendia a seguir uma trajetória de valorização, o que dificultava a administração da política cambial por parte do Banco Central. Por essa razão, o Banco Central passou a interferir de forma mais marcante no mercado cambial, demandando divisas e, consequentemente, aumentando o volume de reservas cambiais acumuladas.

A partir de março de 1994, a taxa de câmbio e a maioria dos preços da economia doméstica passaram a ser corrigidos pela variação da Unidade Real de Valor (URV). O preço máximo de venda de cada dólar norte-americano estabelecido pelo Banco Central passou a ser igual a uma URV. Ou seja, o Banco Central fixou a paridade

\footnotetext{
${ }^{9}$ A discussão da evolução da política cambial brasileira no periodo de janeiro de 1992 a dezembro de 1995 foi baseada nos Relatórios do Banco Central do Brasil, anos 1994-95.
} 
máxima de US\$ $1=1 \mathrm{URV}$. O valor da URV era anunciado previamente, vigorando no dia seguinte. Desse modo, os agentes econômicos conheciam com antecedência a desvalorização nominal máxima, em relação ao dólar, que a moeda nacional poderia sofrer.

Após a implantação da URV, o excesso de oferta de divisas continuava a caracterizar o mercado de câmbio brasileiro. Assim, quase não houve pressões no sentido de se alcançar o valor máximo estabelecido para a taxa de câmbio (que era de uma URV). O Banco Central intervinha no mercado comprando divisas no sentido de tentar assegurar uma certa estabilidade à taxa de câmbio real. Através dessa operação foi possível assegurar variações idênticas entre a taxa de câmbio nominal e a URV, no período de março a junho de 1994.

Em primeiro de julho de 1994, com a entrada em vigor do Real, a política cambial sofreu profundas alterações. O Banco Central abandonou a meta de assegurar estabilidade à taxa de câmbio real, deixando para as forças de mercado a função de determinar o nível desta. A cotação do real tomou como base o valor da URV de 30 de junho, que era CR $\$ 2.750,00$. Assim, estabeleceu-se a paridade $1 \mathrm{URV}=\mathrm{CR} \$ 2.750,00=$ $\mathrm{R} \$ 1,00$. A partir de então, o Banco Central assumiu, inicialmente, o compromisso formal de vender divisas no mercado de câmbio sempre que o limite máximo de paridade, $R \$ 1=$ US\$ 1 , fosse alcançado e tendesse a ser ultrapassado.

Como persistia a entrada de capitais externos estimulada pelo diferencial de taxas de juros reais entre o Brasil e o resto do mundo, a tendência de redução da taxa de câmbio real e nominal também foi mantida. A taxa de câmbio nominal, no segmento comercial, foi ajustada pelo mercado em $\mathrm{R} \$ 0,910$ por dólar para venda, no dia 7 de julho, e em $\mathrm{R} \$ 0,940$ por dólar, no final do mesmo mês. Em final de agosto a cotação do câmbio caiu para $\mathrm{R} \$ 0,889$ por dólar.

$\mathrm{Na}$ tentativa de reverter a tendência de valorização real do câmbio, com base nos próprios mecanismos de mercado, o Banco Central lançou diversas medidas, nos meses de agosto e setembro, com vistas a estimular a demanda por divisas ${ }^{10}$. Não

\footnotetext{
${ }^{10}$ Para saber sobre as medidas lançadas pelo Banco Central, consultar o Relatório do Banco Central do Brasil - 1994, p. 99-100.
} 
obstante, as medidas implementadas não foram suficientes, no curto prazo, para reverter a tendência de valorização do real em relação ao dólar americano. Por essa razão, pela primeira vez após a implantação do Plano Real, o Banco Central foi levado a interferir diretamente no mercado de câmbio comprando divisas, nas duas últimas semanas do mês de setembro de 1994. A mesma prática também foi mantida durante o mês de outubro, ao tempo em que o Banco Central lançou novas medidas no sentido de conter a oferta e estimular a demanda por divisas, tanto no segmento comercial quanto no financeiro.

No mês de dezembro de 1994, o mercado de câmbio do Brasil foi abalado pela crise financeira mexicana, que provocou um forte aumento na demanda por dólares. $\mathrm{Na}$ tentativa de evitar uma desvalorização cambial em proporção indesejável, o Banco Central interferiu no mercado ofertando divisas. Graças ao elevado nível de reservas cambiais acumuladas pelo País, o Banco Central logrou sucesso em suas operações no mercado de câmbio, o que pode ser notado pela estreita amplitude de variação cambial observada ao longo do mês de dezembro, que situou-se em torno de $2 \%$. Além disso, o teto para a paridade entre o real e o dólar ( $R \$ 1=$ US $\$ 1)$, formalmente estabelecido pelo Banco Central, ficou longe de ser alcançado. A taxa de câmbio fechou o ano de 1994 cotada em $\mathrm{R} \$ 0,846$ por dólar americano.

O início do ano de 1995 exigiu redobrada atenção do governo na área cambial. A balança comercial vinha registrando déficits desde o mês de novembro de 1994, e a crise financeira mexicana continuava a induzir saída líquida de divisas do Brasil. No início de março de 1995, a política cambial brasileira foi substancialmente modificada. O Banco Central passou a adotar, efetivamente, o sistema de bandas cambiais. Em tese, nesse sistema, o Banco Central estabelece os limites mínimo e máximo entre os quais a taxa de câmbio pode flutuar livremente. Quando a taxa de câmbio atinge o limite mínimo, sinalizando uma valorização da moeda doméstica, o Banco Central intervém no mercado comprando divisas (e, portando, deslocando a curva de demanda por dólares para cima e para a direita). Contrariamente, quando o limite máximo é alcançado, acusando uma desvalorização cambial, o Banco Central interfere no mercado de câmbio vendendo divisas (e, desse modo, deslocando a curva de oferta por dólares para baixo e para a direita) 
Não obstante, a prática do Banco Central era a de atuar, também, dentro das bandas, com vistas a evitar oscilações indesejáveis na taxa de câmbio. As primeiras bandas cambiais entraram em vigor no dia 06 de março de 1995, apresentando os seguintes limites: $R \$ 0,86$ e $R \$ 0,90$ por dólar americano. Já no dia 10 de março, o Banco Central promoveu a primeira alteração nas bandas cambiais, estabelecendo os novos limites em $\mathrm{R} \$ 0,88$ e $\mathrm{R} \$ 0,93$ por dólar, que deveriam prevalecer por tempo indeterminado. As alterações das bandas cambiais visaram adequar o câmbio à realidade do mercado.

As intervenções do Banco Central que se seguiram após a implantação do sistema de bandas cambiais visavam promover gradual desvalorização nominal do real em relação ao dólar, sem, contudo, sinalizar para o mercado a periodicidade e a intensidade dessas desvalorizações. Com essa estratégia, o Banco Central buscava evitar a especulação contra a moeda doméstica, a deterioração da receita das exportações e o ressurgimento do processo de indexação de preços atrelado ao câmbio.

Em 22 de junho 1995, as bandas cambiais foram alteradas pela terceira vez. Os novos limites mudaram para $\mathrm{R} \$ 0,91$ e $\mathrm{R} \$ 0,99$ por dólar. As bandas cambiais ficaram mais distantes, tendo a diferença entre o limite inferior e o superior passado de $5,68 \%$ para $8,79 \%$. A ampliação das bandas cambiais proporcionou maior flexibilidade ao Banco Central na condução da política cambial. Ao mesmo tempo, contribuiu para aumentar a expectativa, por parte dos agentes econômicos, de desvalorização da moeda doméstica. Por essa razão, a demanda por divisas foi imediatamente aumentada logo após o anúncio das novas bandas.

No período de julho de 1994, início do Real, até o final do ano de 1995 a taxa de câmbio nominal (paridade real/dólar) tinha acumulado uma variação percentual de aproximadamente $3,80 \%{ }^{11}$. Tomando-se por base a evolução dos preços medida pelo IPA-DI doméstico e o IPA dos Estados Unidos, que foram de $24,09 \%$ e 4,36\% para o período acima mencionado, respectivamente, tem-se que a desvalorização nominal que deveria ter ocorrido para manter a taxa de câmbio real no mesmo patamar de julho de

\footnotetext{
${ }^{11}$ A taxa de câmbio média (comercial) dos meses de julho de 1994 e dezembro de 1995 foram de R\$ $0,933=$ US $\$ 1,00$ e R $\$ 0,9685=$ US $\$ 1,00$, respectivamente.
} 
1994 seria de aproximadamente 18,91\%. Portanto, a defasagem cambial acumulada durante 18 meses de vigência da atual moeda do País, o Real, ficou em torno de 14,55\%. Não obstante, se se considerar como indicador da inflação doméstica o IGP-DI, que acusou um índice de 58,73\% no período de julho a dezembro de 1995 , a desvalorização nominal da taxa de câmbio para manter a paridade real de julho de 1994 teria sido de aproximadamente $52,10 \%$. Portanto, utilizando-se esse índice como medida da inflação doméstica, a defasagem cambial acumulada em 18 meses de vigência do Real foi de aproximadamente de $46,53 \%$.

Percebe-se, do exposto acima, que a magnitude da defasagem cambial acumulada em 18 meses de Plano Real depende do índice que se utiliza como medida da inflação doméstica. De acordo com Zini Jr. (1993, p. 25, 32 e 131) o Índice de Preços no Atacado (IPA) capta as variações de preços em nível de produtores e reflete, sobretudo, os preços dos produtos industrializados e agrícolas exportáveis. O índice IPA acompanha a evolução dos preços dos produtos que podem ser comercializados internacionalmente, continua o mesmo autor. Ainda de acordo com Zini Jr. (1995, p. 25), o IPA é o indicador de inflação que melhor capta as variações nos custos dos produtores e, portanto, reflete mais fielmente a competitividade de uma economia. Por essa razão, o índice é frequentemente utilizado como deflator da taxa de câmbio nominal.

Por outro lado, o Índice Geral de Preços (Disponibilidade Interna) reflete melhor a evolução dos preços praticados em toda a economia. Por essa razão, o IGP-DI inclui a evolução de preços de vários produtos e serviços que não são comercializáveis internacionalmente, os quais não afetam diretamente a competitividade de uma economia

Até o momento foram analisados os efeitos da política cambial brasileira sobre a evolução da taxa de câmbio real e nominal de paridade (moeda doméstica/dólar americano). Em seguida, passa-se a avaliar o comportamento da taxa de câmbio efetiva real no período de 1961 a 1995. 


\subsection{Evolução da taxa de câmbio efetiva real e da taxa de câmbio reàl}

A evolução da taxa de câmbio efetiva real depende da inflação dos nossos principais parceiros comerciais, da inflação doméstica e da evolução da taxa de câmbio nominal de cada país considerado em relação ao dólar americano.

$\mathrm{Na}$ Figura 2, apresenta-se a evolução da taxa de câmbio efetiva real do Brasil no período de 1961 a 1995. Duas versões são reportadas. Na primeira versão, a taxa de câmbio efetiva usa um deflator contendo o Índice de Preços no Atacado (IPA) dos principais parceiros comerciais do Brasil no numerador e o IPA doméstico no denominador, é a e-IPA. A segunda versão da taxa de câmbio efetiva usa um deflator constituído pelo IPA dos principais parceiros comerciais do Brasil no numerador e o Índice de Preços ao Consumidor (IPC-RJ da FGV) no denominador, é a e-TNT ${ }^{12}$. Uma elevação no índice acusa uma desvalorização real do câmbio. Essas taxas estão apresentadas na forma de índice, com 1985 sendo igual a 100. Para o período que sucede o ano base, há ganho de competitividade do país em relação aos seus parceiros comerciais se a taxa de câmbio ultrapassa seu nível de referência do ano base.

De acordo com Zini Jr. (1993, p. 23), vários fatores indicam que em 1985 a taxa real de câmbio estava relativamente alinhada com a competitividade externa do país, dentre eles destacam-se: "o balanço de pagamentos equilibrado, o baixo ágio do dólar no mercado paralelo e os estudos sobre a proteção efetiva no Brasil, que mostram uma situação não muito distorcida naquele ano".

\footnotetext{
${ }^{12}$ A fórmula para calcular a taxa de câmbio efetiva real pode ser encontrada em Zini Jr. (1993, p. 134).
} 


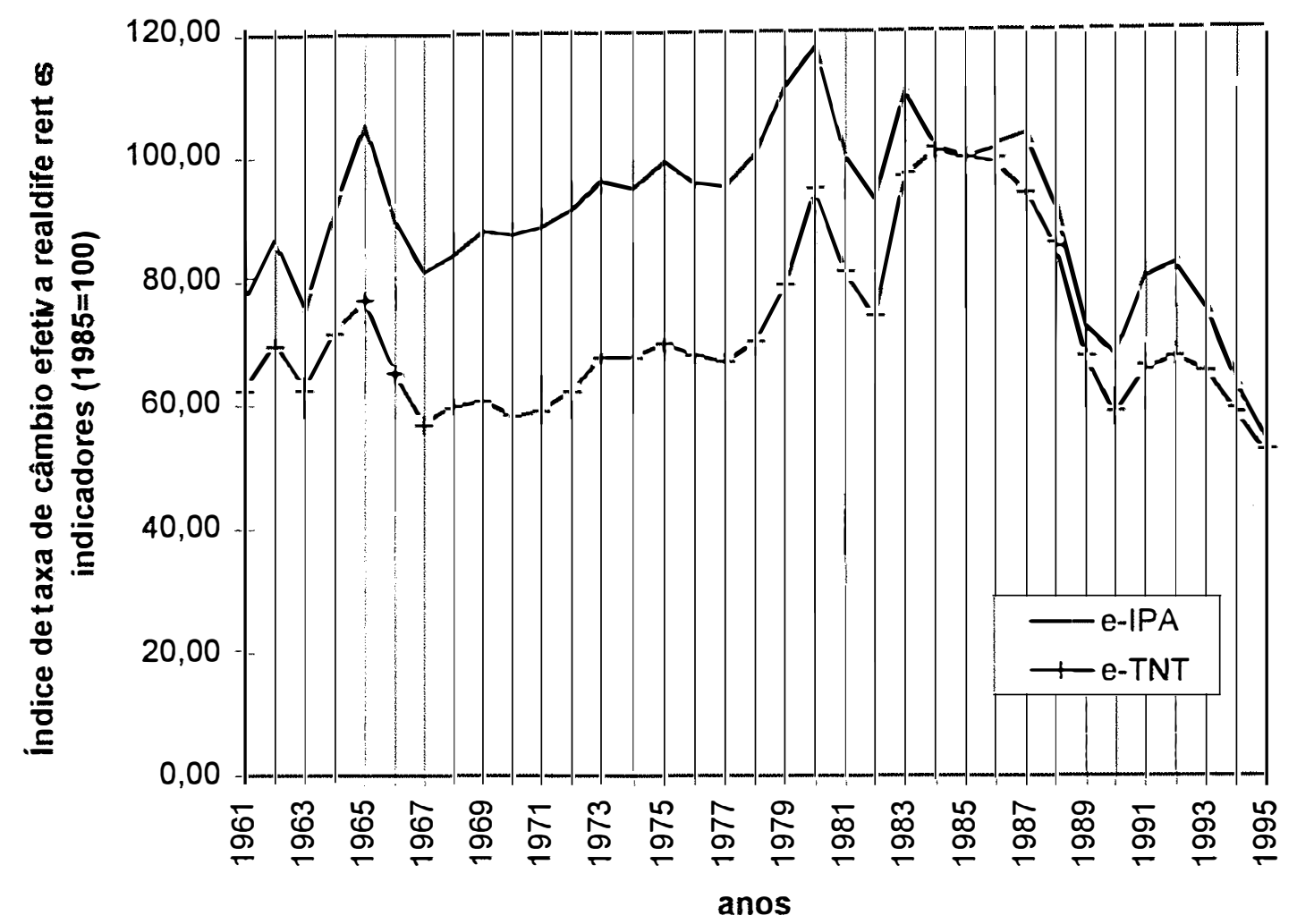

Fonte: elaborada com base nos dados fornecidos pessoalmente por Antônio Álvaro Zini Jr.

Figura 2. Evolução da taxa de câmbio efetiva real do Brasil no período de 1961 a 1995 (diferentes indicadores).

Observa-se na Figura 2 que as taxas efetivas reais de câmbio e-IPA e eTNT apresentaram comportamento similar ao longo do período de 1961 a 1995. Verifica-se, também que, no período anterior à política de minidesvalorizações cambiais, as variações na taxa de câmbio foram maiores que aquelas observadas no período imediatamente após a implantação da política de minidesvalorizações cambiais (1968 a 1978). Após a ocorrência do segundo choque do petróleo em 1979, a variação da taxa de câmbio efetiva real voltou a aumentar. Dois fatores contribuíram para o aumento da variação da taxa de câmbio efetiva real a partir de 1979, quais sejam: a) mudanças (com maior freqüência) no valor da moeda americana frente às moedas dos principais parceiros 
comerciais do Brasil, notadamente as moedas européias e japonesa; e, b) retomada, em alguns anos, da política brasileira de maxidesvalorizações cambiais.

Os dois índices da taxa de câmbio efetiva real acusam elevadas desvalorizações da moeda doméstica nos anos de 1965, 1979, 1980, 1983 (ver Figura 2). A elevação nos índices para os anos de 1979 e 1980 podem ser explicadas pela apreciação das moedas de nossos principais parceiros comerciais em relação ao dólar e pela maxidesvalorização nominal de $30 \%$ da moeda doméstica decretada pelo Banco Central em dezembro de 1979, também em relação ao dólar. Em 1983, o Banco Central decretou outra maxidesvalorização nominal de 30\% da moeda doméstica frente à moeda norte americana, contribuindo para a elevação dos índices naquele ano. Em 1987, o dólar voltou a se desvalorizar frente às moedas européias e japonesa, e o índice de taxa de câmbio efetiva e-IPA acusa novamente uma desvalorização real.

De 1988 a 1990 os dois índices acusam valorizações reais do câmbio. As valorizações registrada só não foram maiores porque no período de 1986 a 1990 o dólar se desvalorizou frente às moedas européias e japonesa (ver Teixeira, 1995). Parte da valorização acumulada nesse período é recuperada em 1991 e 1992. Não obstante, a partir de 1993 a valorização cambial acumulada volta a aumentar. Em 1995 os dois índices atingem os menores valores dos 35 anos em análise (ver Figura 2).

De modo geral, as desvalorizações nominais da moeda domésticas, em relação ao dólar norte-americano, praticadas no período de 1988 a 1989 não foram suficientes para compensar a inflação doméstica medida pelo Índice de Preço no Atacado (IPA) e pelo Índice de Preços ao Consumidor (IPC), o que pode explicar parte das valorizações cambiais acusadas pelos índices (e-IPA) e (e-TNT) para os anos de 1988 a 1989. A forte valorização cambial no ano de 1990 resultou, sobretudo, da contração no nível de liquidez da economia, que foi o principal instrumento do Plano Collor para conter a inflação doméstica. De 1994 a 1995 a taxa de câmbio acumulou um substancial atraso em relação a seu nível de paridade real de referência (a taxa vigente em 1985). Esse atraso cambial resultou da estratégia do governo de combinar dois instrumentos de política econômica (o cambial e o monetário) para reduzir a inflação. A manutenção de uma política monetária restritiva contribuia para aumentar o diferencial entre as taxas de 
juros reais doméstica e internacional, estimulando o ingresso de recursos externos e, assim, pressionando a taxa de câmbio no sentido de uma valorização.

Para comparar, ao longo do tempo, a defasagem acumulada da taxa de câmbio real e da taxa de câmbio efetiva real são apresentadas, no Quadro 1, duas versões de cada um desses conceitos. O ano base das séries é 1985, escolhido por ter sido um ano de estabilidade nos mercados cambiais do Brasil (ver página 16 deste capítulo).

Como deflatores da taxa de câmbio nominal de paridade utilizam-se 0 Índice de Preços no Atacado (IPA) dos Estados Unidos e o Índice de Preços no Atacado do Brasil, obtendo-se, assim, a taxa de câmbio real de paridade (e-IPAP). Uma segunda versão da taxa de câmbio de paridade (e-DPIB) foi obtida utilizando como numerador o deflator implícito do produto doméstico bruto dos Estados Unidos e o deflator implícito do produto interno bruto do Brasil como denominador.

A taxa de câmbio efetiva foi deflacionada pelo IPA dos principais parceiros comerciais do Brasil e pelo IPA doméstico. Alternativamente, apresenta-se também uma segunda versão da taxa de câmbio efetiva (e-TNT), que utiliza como deflator dos preços no Brasil o Índice de Preços ao Consumidor, mantendo-se o IPA dos parceiros comerciais no numerador. O principal argumento a favor do conceito (e-TNT) reside no fato do IPA dos parceiros comerciais do país ser considerado como uma proxy do preço internacional dos bens comercializáveis internacionalmente (tradable goods), enquanto o IPC doméstico seria uma proxy do preço dos bens não comercializáveis internacionalmente (nontradable goods), por considerar, em sua construção, uma grande proporção dos bens não comercializáveis no mercado internacional.

Observa-se no Quadro 1 que, quando se utiliza o ano de 1985 como base para o cálculo da taxa de câmbio real, todos os índices apontam uma valorização real do câmbio ao longo do período de 1986 a 1995. As únicas exceções foram para os anos de 1986 e 1987, quando se considera o conceito de taxa de câmbio efetiva real (e-IPA), que acusa desvalorizações reais do câmbio nos referidos anos. 
Quadro 1. Taxa de câmbio real do Brasil (diferentes indicadores) e estimativas das desvalorizações e valorizações reais do câmbio no período de 1985 a 1995 (Base 1985=100).

\begin{tabular}{|c|c|c|c|c|}
\hline \multirow[t]{2}{*}{ Ano } & \multicolumn{2}{|c|}{ Taxa de câmbio real (cesta de moedas) } & \multicolumn{2}{|c|}{ Taxa de câmbio real (R\$/US\$) } \\
\hline & e-IPA ${ }^{(1)}$ & e-TNT ${ }^{(1)}$ & e-IPAP(1) & e-DPIB ${ }^{(\langle)}$ \\
\hline 1985 & 100,00 & 100,00 & 100,00 & 100,00 \\
\hline 1986 & 101,66 & 99,48 & 89,07 & 90,37 \\
\hline 1987 & 103,48 & 94,36 & 85,43 & 88,14 \\
\hline 1988 & 92,16 & 85,59 & 74,58 & 84,49 \\
\hline 1989 & 72,65 & 67,34 & 61,08 & 67,04 \\
\hline 1990 & 68,21 & 58,51 & 55,54 & 62,48 \\
\hline 1991 & 80,84 & 65,95 & 65,48 & 75,52 \\
\hline 1992 & 83,19 & 67,98 & 66,77 & 78,64 \\
\hline 1993 & 75,78 & 65,54 & 59,94 & 72,84 \\
\hline 1994 & 63,41 & 58,92 & 49,47 & 62,36 \\
\hline 1995 & 54,70 & 52,35 & 42,11 & 51,99 \\
\hline \multicolumn{5}{|c|}{$\begin{array}{c}\text { Desvalorização (+) e Valorização (-) da taxa de câmbio real em pontos percentuais } \\
\text { acumulados em relação à base }\end{array}$} \\
\hline Ano & e-IPA & e-TNT & e-IPAP & e-DPIB \\
\hline 1986 & $+1,66$ & $-0,52$ & $-10,93$ & $-9,63$ \\
\hline 1987 & $+3,48$ & $-5,64$ & $-14,57$ & $-11,86$ \\
\hline 1988 & $-7,84$ & $-14,41$ & $-25,42$ & $-15,51$ \\
\hline 1989 & $-27,35$ & $-32,66$ & $-38,92$ & $-32,96$ \\
\hline 1990 & $-31,79$ & $-41,49$ & $-44,46$ & $-37,52$ \\
\hline 1991 & $-19,16$ & $-34,05$ & $-34,52$ & $-24,48$ \\
\hline 1992 & $-16,81$ & $-32,02$ & $-33,23$ & $-21,36$ \\
\hline 1993 & $-24,22$ & $-34,46$ & $-40,06$ & $-27,16$ \\
\hline 1994 & $-36,59$ & $-41,08$ & $-50,53$ & $-37,64$ \\
\hline 1995 & $-45,30$ & $-47,65$ & $-57,89$ & $-48,01$ \\
\hline
\end{tabular}

Fonte: ${ }^{(1)}$ Antônio Álvaro Zini Jr. (fonte direta); (2) Cálculo do autor com base nos dados do Banco Central do Brasil (taxa de câmbio nominal), da FGV-Conjuntura Econômica (deflator implícito do PIBBrasil) e do IMF-International Financial Statistics Yearbook (deflator implícito do GDP dos EUA).

As defasagens reais do câmbio calculadas a partir dos indicadores de taxa de câmbio (e-IPA), (e-TNT), (e-IPAP) e (e-DPIB) no ano de 1995 foram, em pontos percentuais, 45,30, 47,65, 57,89 e 48,01, respectivamente (ver Quadro 1).

Se se considerar como base da taxa de câmbio real o ano de 1988, conforme recomenda o Instituto de Pesquisas Econômicas Aplicadas, verifica-se que todos os índices acusam valorizações reais do câmbio no período de 1989 a 1995 (ver Quadro 2). Não obstante, qualquer que seja o conceito de taxa de câmbio adotado, 
quando se utiliza 1988 como base a magnitude das defasagens cambiais no período de 1989 a 1995 são menores do que quando se utiliza como referência o ano de 1985.

Quadro 2. Taxa de câmbio real do Brasil (diferentes indicadores) e estimativas das desvalorizações e valorizações reais do câmbio no período de 1988 a 1995 (Base 1988=100).

\begin{tabular}{|c|c|c|c|c|}
\hline \multirow[t]{2}{*}{ Ano } & \multicolumn{2}{|c|}{ Taxa de câmbio real (cesta de moedas) } & \multicolumn{2}{|c|}{ Taxa de câmbio real (R\$/US\$) } \\
\hline & e-IPA & e-TNT & e-IPAP & e-DPIB \\
\hline 1988 & 100 & 100 & 100 & 100 \\
\hline 1989 & 78,83 & 78,68 & 81,89 & 79,35 \\
\hline 1990 & 74,01 & 68,36 & 74,47 & 73,95 \\
\hline 1991 & 87,71 & 77,05 & 87,79 & 89,39 \\
\hline 1992 & 90,26 & 79,43 & 89,52 & 93,07 \\
\hline 1993 & 82,23 & 76,58 & 80,37 & 86,21 \\
\hline 1994 & 68,81 & 68,84 & 66,33 & 73,80 \\
\hline 1995 & 59,36 & 61,17 & 56,46 & 61,54 \\
\hline \multicolumn{5}{|c|}{$\begin{array}{c}\text { Desvalorização }(+) \text { e Valorização }(-) \text { da taxa de câmbio real em pontos percentuais } \\
\text { acumulados em relação à base }\end{array}$} \\
\hline Ano & e-IPA & e-TNT & e-IPAP & e-DPIB \\
\hline 1989 & $-21,17$ & $-21,32$ & $-18,11$ & $-20,65$ \\
\hline 1990 & $-25,99$ & $-31,64$ & $-25,53$ & $-26,05$ \\
\hline 1991 & $-12,29$ & $-22,95$ & $-12,21$ & $-10,61$ \\
\hline 1992 & $-9,74$ & $-20,57$ & $-10,48$ & $-6,93$ \\
\hline 1993 & $-17,77$ & $-23,42$ & $-19,63$ & $-13,79$ \\
\hline 1994 & $-31,19$ & $-31,16$ & $-33,67$ & $-26,20$ \\
\hline 1995 & $-40,64$ & $-38,83$ & $-43,54$ & $-38,46$ \\
\hline
\end{tabular}

Fonte: Vide Quadro 1.

Portanto, constata-se que a magnitude da defasagem cambial depende essencialmente do conceito de taxa de câmbio adotado (se bilateral ou efetiva), dos deflatores utilizados e do período base de referência.

Ademais, observa-se ainda nos Quadros 1 e 2 que houve um expressivo aumento da defasagem real do câmbio após a implantação do Plano Real no ano de 1994.

De modo geral, as fontes de valorização cambial no período de 1986 a 1995 têm sido o diferencial entre taxas de juros reais interna e externa, o "congelamento" da taxa nominal de câmbio, a presença de algum resíduo inflacionário ou a retomada da própria inflação (alguns meses após a implantação dos planos de estabilização). No Plano Real, a principal fonte de valorização cambial continua sendo o 
diferencial entre taxas de juros reais interna e externa. Segundo informações do Ministério da Fazenda, o diferencial entre taxas de juros reais interna e externa persistirá enquanto o Governo não conseguir conter o déficit público, uma vez que para financiá-lo torna-se necessário a emissão de títulos ${ }^{13}$. Assim, mantida a confiança dos investidores estrangeiros com relação à economia brasileira, a tendência de valorização da moeda doméstica continuará enquanto o déficit público não for contido.

A tendência de valorização da taxa real de câmbio (efetiva e bilateral) constatada estará sinalizando problemas futuros para o ajustamento do saldo da balança comercial agrícola total se, de fato, a taxa real de câmbio for uma variável relevante na determinação desse saldo.

No próximo capítulo são apresentados, com base em revisão de literatura, os efeitos das desvalorizações reais do câmbio sobre as transações externas com mercadorias no Brasil, com o propósito de evidenciar que os objetivos da presente pesquisa, levantados no capítulo 1 , ainda não foram devidamente estudados no Brasil.

\footnotetext{
${ }^{13}$ Para que o Governo possa vender seus títulos, é necessário pagar uma taxa de juros real atrativa em relação aos títulos privados.
} 


\section{TAXA DE CÂMBIO E TRANSAÇÕES EXTERNAS COM MERCADORIAS NO BRASIL}

Como constatado no capítulo 2, o Brasil teve, no período de 1961 a 1995, diversas políticas cambiais, com distintos impactos sobre o valor real da taxa de câmbio. No presente capítulo são revisados os trabalhos sobre taxa de câmbio e transações externas com mercadorias no Brasil.

Uma desvalorização real da moeda nacional aumenta a rentabilidade das exportações e o custo das importações em moeda doméstica, tendendo a produzir um superávit no saldo comercial. A política inversa, ou seja, uma valorização cambial, ao reduzir a rentabilidade das exportações e diminuir os custos das importações, pode conduzir a um déficit no balanço comercial.

A valorização da moeda nacional em relação a uma moeda externa de referência "é um imposto implícito sobre as exportações cuja incidência na economia interna cresce à proporção que a elasticidade da demanda externa cresce" (Schuh, 1983, p. 92). Para a maioria dos produtos que o Brasil exporta a participação do País no mercado internacional pode ser considerada marginal. Assim sendo, a elasticidade-preço da demanda global deve ser alta, o que implica elevado imposto sobre o setor exportador com a sobrevalorização da moeda doméstica (Schuh, 1977).

Uma das poucas situações onde a valorização cambial é desejável para o país ocorre quando este é formador de preços no mercado internacional de um determinado produto cuja elasticidade-preço da demanda é menor que um em valor absoluto, caso do café enquanto o Brasil era fixador do preço internacional desse produto (ver Schuh, 1977; e, Almeida, 1993). Nessa situação, uma valorização da taxa de câmbio 
real tem como efeito a elevação da receita, através do aumento de preços em moeda estrangeira mais do que proporcional à redução da quantidade demandada.

Diversos trabalhos abordaram a sistemática e resultados da política cambial adotada no Brasil. Por exemplo, Senna (1974), Silva (1976), Suplicy (1976), Almonacid (1979) e Zini Jr. (1989 e 1993), dentre outros, analisaram as bases da política de minidesvalorizações cambiais. Os dois últimos autores distinguiram os choques reais dos choques monetários, ao tempo em que sugerem a inadequação da regra de desvalorizações baseada na paridade do poder de compra para equilibrar as contas externas do país em situações onde se tem choques reais (choque do petróleo e recessão mundial, por exemplo) ${ }^{14}$. A mesma conclusão foi sugerida, anteriormente, pelos trabalhos de Pastore et al (1976 e 1978) ao estudarem o atraso cambial durante o ano de 1974.

Estudos que tratam do impacto da taxa de câmbio sobre o setor externo brasileiro foram desenvolvidos por vários autores ${ }^{15}$. Os temas mais comumente estudados são os efeitos da taxa de câmbio sobre as exportações de produtos manufaturados, produtos básicos e o saldo da balança comercial. A variável câmbio tem sido operacionalizada de diversas formas, sendo os conceitos de taxa real e taxa efetiva real os mais utilizados. As elasticidades-câmbio encontradas não são de um mesmo valor, variando conforme o período de análise, o grau de agregação dos dados e o método de estimação.

As evidências empíricas tendem a confirmar que a taxa de câmbio é uma variável importante nas relações comerciais do País com o resto do mundo. Neste sentido, pode-se apontar as elasticidades-câmbio calculadas por Suplicy (1976) e Viana (1993) para as exportações brasileiras de produtos manufaturados que foram de 1,79 e 0,969, respectivamente. Do mesmo modo, Tyler (1982) informa, com base em estudos

\footnotetext{
${ }^{14}$ O primeiro choque do petróleo ocorreu em outubro de 1973, mas seu efeito sobre a balança comercial somente se verificou nos três anos subsequentes. O segundo choque teve lugar em 1979, com efeito sobre a balança em 79 e 80. De 1980 a 1982, a economia mundial entrou em recessão e a balança comercial brasileira registrou novamente uma deterioração.

${ }^{15}$ Ver, por exemplo, os trabalhos de Pastore et al (1976 e 1978); Bacha (1977); Sayad (1979a e 1979b); Cardoso (1979 e 1981); Silva \& Locatelli (1987); e, Locatelli \& Silva (1991).
} 
para as exportações de produtos manufaturados do Brasil disponíveis na literatura, que as elasticidades-câmbio relevantes têm variado de 1 a 1,5.

Analisando o efeito de uma desvalorização sobre a receita de exportações, em dólares, de produtos manufaturados do Brasil, a partir de modelos de equilíbrio e desequilíbrio, Braga \& Markwald (1983) concluíram que os efeitos de longo prazo são maiores que os de curto prazo. Estimativas menos otimistas foram obtidas por Martner (1992) que, ao simular os efeitos de uma desvalorização cambial sobre a economia brasileira, sugere que o instrumento cambial tem um impacto limitado sobre a geração de divisas provenientes das exportações. A importância dessa simulação decorre do fato de a hipótese de Marshall-Lerner, comumente assumida nas estimações das equações de comércio exterior brasileiro, não ter sido considerada.

No que concerne ao efeito da taxa de câmbio sobre a balança comercial, Braga \& Rossi (1986) apresentam como elasticidade média de longo prazo o coeficiente de 2,5. No trabalho de Zini Jr. (1993), os resultados encontrados revelam que o saldo da balança comercial brasileira responde com defasagem de um ano às variações na taxa de câmbio efetiva real.

Os trabalhos comentados até o momento fizeram uso de técnicas econométricas tradicionais para medir os efeitos das variações na taxa de câmbio sobre as exportações de produtos manufaturados e sobre o saldo da balança comercial brasileira. O problema dos procedimentos utilizados é que as estimativas encontradas podem revelar relações espúrias (isto é, relações que podem não ser verdadeiras) entre a variável dependente e as variáveis consideradas ao lado direito da equação de regressão, denominadas regressores. Essa possibilidade sempre existe se as variáveis utilizadas na estimação da regressão não são estacionárias e a combinação linear entre elas produz um termo de erro também não-estacionário.

O procedimento usual para evitar o problema de regressão espúria tem sido o de estimar a regressão nas primeiras diferenças das variáveis. Uma crítica que, geralmente, é feita quando se utilizam as variáveis em primeiras diferenças para estimar a regressão é que as informações de longo prazo são perdidas. Assim sendo, os coeficientes estimados estariam refletindo apenas ajustamentos de curto prazo. Caso exista uma 
relação de longo prazo entre as variáveis analisadas, tal procedimento, ao deixar de captar esse efeito, levaria a um erro de especificação do modelo ${ }^{16}$.

$\mathrm{Na}$ década de oitenta foi desenvolvida a análise de co-integração, que permite testar se séries não-estacionárias em nível mantêm uma relação linear de equilíbrio estável no longo prazo. Se este for o caso, então existe uma representação de correção de erros que mostra o comportamento dinâmico de curto prazo entre as séries consideradas. $\mathrm{O}$ uso desses instrumentais permite estimar regressões a partir de variáveis não-estacionárias - desde que algumas condições sejam satisfeitas (como veremos no capítulo 5) - sem contudo incorrer no risco de encontrar relações espúrias.

Os sistemas co-integrados e suas representações de correção de erros passaram, então, a ser utilizados, principalmente, para estudar as relações entre variáveis macroeconômicas. Dentro deste contexto, as estimativas das equações da conta corrente e da balança comercial também foram incluídas. A título de exemplo, podem-se citar os trabalhos de Boucher (1991), que estimou uma equação para a conta corrente dos Estados Unidos; e o trabalho de Rose (1991), que estimou equações para a balança comercial de cinco países: Reino Unido, Canadá, Alemanha, Japão e Estados Unidos. Em ambos os trabalhos a hipótese de co-integração entre a variável dependente (conta corrente ou balança comercial) e as variáveis independentes (renda interna, renda externa e um índice de competitividade de preços), testada por meio do método de Engle e Granger, foi rejeitada. Isto significa que não foi encontrada uma relação estável de longo prazo entre o saldo da conta corrente ou da balança comercial e as variáveis explanatórias citadas acima.

Procurando determinar se existe uma relação estável de longo prazo entre a evolução da taxa de câmbio brasileira e o saldo da balança comercial, Ferreira (1993), analisando o período 1982/90, e Nunes (1994), cobrindo o período de janeiro de 1975 a março de 1991, empregaram também a análise de co-integração pelo método de

\footnotetext{
${ }^{16}$ Dois outros procedimentos podem ser utilizados para contornar o problema de regressão espúrias. O primeiro consiste em incluir valores defasados da variável dependende e da variável explanatória ao lado direito da equação de regressão. O segundo procedimento utiliza o ajustamento de Cochrane-Orcutt para eliminar a autocorrelação serial entre os resíduos. Para mais detalhes e implicações associadas a estes procedimentos consultar Hamilton (1994, p. 557-62).
} 
Engle e Granger. Os resultados encontrados pelos dois autores confirmam a existência de uma relação positiva de longo prazo entre desvalorizações da moeda doméstica e o saldo comercial. Deve-se, porém, ressaltar que no trabalho do último autor (Nunes, 1994) somente se verificou essa associação quando foi utilizado o conceito de taxa de câmbio real (deflacionada pelo IPA dos Estados Unidos e ICV do Brasil).

Estimativas mais sofisticadas de equações de exportações e importações para o Brasil foram feitas mais recentemente por Castro e Cavalcanti (1997). Os autores partiram dos testes para relações co-integradas a partir do método desenvolvido por Johansen, que é indicado, sobretudo, quando o número de variáveis consideradas no modelo é maior que dois. As estimações foram realizadas considerando-se tanto as exportações quanto as importações nas formas totais e desagregadas. Do lado das exportações, consideraram-se as seguintes categorias: exportações totais; exportações de produtos manufaturados; exportações de produtos semimanufaturados; e, exportações de produtos básicos. No que concerne às importações, analisaram-se os seguintes tipos: importações totais; importações de bens de capital; importações de bens intermediários; e, importações de bens de consumo.

Para todas as equações de exportações estimadas por Castro e Cavalcanti (1997), constatou-se que a taxa de câmbio pode ser considerada uma variável exógena e que as variações na taxa de câmbio real têm um efeito positivo a curto e longo prazos sobre os valores exportados por categoria de produto. As exceções são os efeitos de curto prazo das variações da taxa de câmbio sobre o valor das exportações totais e sobre o valor das exportações de produtos básicos, que se mostraram estatisticamente não significativos.

No que concerne às equações de importações estimadas por Castro e Cavalcanti (1997), concluiu-se que a taxa de câmbio também pode ser considerada uma variável exógena e que suas variações têm um efeito negativo a curto e longo prazos sobre o valor das importações das categorias analisadas.

Trabalhos que versam sobre câmbio e transações externas com produtos da agricultura são menos numerosos. Segundo Suplicy (1976), citando as 
estimativas de Doellinger ${ }^{17}$ para o período $1963 / 68$, a elasticidade-câmbio calculada para as exportações dos produtos primários não-tradicionais ${ }^{18}$ foi igual a 0,54 . Avaliando os efeitos das minidesvalorizações sobre as exportações de produtos básicos no período 1964/71, Suplicy encontrou a mesma elasticidade-câmbio calculada por Doellinger ${ }^{19}$. Os dois autores partiram de uma equação de oferta de exportação na forma logaritmica para determinar os valores das elasticidades.

Almeida (1993), considerando o periodo 1970/89, estimou uma equação de oferta de exportação de café do Brasil a partir de um sistema recursivo de equações. A variável câmbio foi incluída como uma das variáveis independentes, tendo obtido um coeficiente de elasticidade-câmbio para o café similar ao encontrado por Doellinger para os produtos primários não-tradicionais, e o encontrado por Suplicy para as exportações de produtos básicos

Decompondo a variação da receita (em moeda nacional) das exportações de café em grão, farelo de soja e suco de laranja induzida por uma mudança nas variáveis câmbio, preço externo e quantidade exportada, no período de junho a dezembro de 1994, Carvalho (1995) sugere que a variável câmbio exerceu menor impacto que as demais sobre a variação da receita dessas exportações. Não obstante, informa a autora, em certos momentos a taxa de câmbio foi um dos fatores determinantes da variação da receita de exportação para os produtos acima citados

Embora as evidências empíricas acima citadas tenham revelado um efeito limitado da taxa de câmbio sobre a receita de exportação de produtos da agricultura, ao mesmo tempo elas sugerem que não se deve negligenciar o papel dessa variável, ainda mais se se considerar que as elasticidades são alteradas no tempo, podendo mudar de acordo com o período em análise, "grau" de agregação dos dados, operacionalização da variável e método de estimação, entre outros. Além disso, a economia brasileira passou por um forte processo de indexação de preços a partir da segunda metade da década de 70, contribuindo para reduzir os efeitos das desvalorizações nominais da moeda

\footnotetext{
${ }^{17}$ Ver Doellinger et al. Exportações dinâmicas brasileiras. Rio de Janeiro, IPEA, 1971.

${ }^{18}$ Agrega todos os produtos primários, exceto café, cereais, algodão, cacau, banana e cera de carnaúba.

${ }^{19}$ Entre os produtos que compõem a cesta estão algodão, cacau, açúcar e minério de ferro. O café não foi incluído.
} 
doméstica sobre as variações da taxa de câmbio real e, conseqüentemente, a resposta das exportações às desvalorizações da moeda doméstica. Ademais, os trabalhos que versam sobre câmbio e produtos da agricultura não distinguem entre os efeitos de curto e longo prazos.

Os estudos realizados até então analisam, com base em técnicas econométricas tradicionais, o efeito da taxa de câmbio sobre produtos ou grupo de produtos agrícolas, mas não sobre o saldo comercial de produtos agrícolas e agroindustriais (também denominado de saldo comercial agrícola total). Sabe-se que o objetivo da política cambial é afetar o saldo total do comércio. A importância de se avaliar o impacto sobre um produto ou grupo de produtos diminui à medida que se tem conhecimento que a direção da política cambial não muda em função de um ou outro produto, a menos que o mesmo detenha uma parcela dominante na geração de divisas do país, caso do café no Brasil nas três primeiras décadas do presente século. Assim sendo, e como ressaltado anteriormente, a presente pesquisa procura determinar os efeitos da taxa de câmbio e de variáveis macroeconômicas sobre o saldo comercial de produtos agrícolas e agroindustriais, considerados no agregado, por representarem, em conjunto, a maior fonte de superávits comerciais gerados no período em análise (1961 a 1995).

No próximo capítulo, passa-se a analisar como as abordagens teóricas incorporaram a taxa de câmbio afetando o saldo da balança comercial de um país, e que outras variáveis também foram consideradas. 


\section{REFERENCIAL TEÓRICO}

Este capítulo analisa três abordagens básicas de ajustamento da Balança Comercial: o enfoque das elasticidades, o enfoque da absorção e uma versão parcial do modelo IS-LM-BP, aqui denominada de modelo IS-TB (item 4.1). O propósito é verificar de que forma a taxa de câmbio afeta a balança comercial segundo as abordagens acima citadas, bem como identificar as variáveis fundamentais a cada enfoque e suas relações com o saldo da balança comercial. No item 4.2 são utilizados o arcabouço teórico, previamente considerado, e os trabalhos empíricos como fontes de "inspiração" na seleção das variáveis incluídas no modelo a ser estimado.

O modelo monetário básico de determinação do saldo do balanço de pagamentos não foi considerado porque o mesmo se dedica a explicar o ajustamento global do balanço de pagamentos resultante da interação entre a oferta e a demanda por moeda na economia doméstica, dando pouca importância aos ajustamentos que ocorrem do lado real da economia (oferta e demanda de bens e serviços), que são de maior interesse na presente pesquisa.

\subsection{Abordagens de ajustamento da balança comercial}

As abordagens de ajustamento da balança comercial estabelecem diferentes condições e distintos mecanismos de transmissão para explicar os efeitos de uma desvalorização cambial sobre o saldo da balança comercial.

O enfoque das elasticidades investiga o impacto de uma desvalorização cambial sobre o saldo da balança comercial quando os termos de troca variam e a renda permanece constante. Portanto, a ênfase é dada ao papel dos preços relativos no processo 
de ajustamento da balança comercial, com os resultados fundamentais dependendo das elasticidades-preço da oferta e da demanda das exportações e importações.

No enfoque da absorção, procura-se avaliar como a desvalorização cambial afeta a relação entre a renda e a absorção. Tomando por base a identidade entre a renda nacional e o dispêndio em uma economia aberta, deriva-se uma identidade na qual o saldo da conta corrente é igual à diferença entre a renda nacional e a absorção doméstica. $O$ ponto central da análise é investigar de que modo a desvalorização cambial afeta a renda e a absorção.

O enfoque das elasticidades e o enfoque da absorção podem ser vistos como complementares, abordando o papel de diferentes variáveis no processo de ajustamento da balança comercial ou da conta corrente. Foi a partir da combinação destas duas abordagens que surgiu o modelo IS-LM-BP, que estabelece as condições para alcançar, simultaneamente, o equilibrio interno e externo em uma economia aberta, através da combinação de dois ou mais instrumentos de política econômica, quais sejam: o instrumento monetário, o fiscal e o cambial. As principais contribuições para a construção do modelo IS-LM-BP partiram de Meade (Williamson, 1989) ${ }^{20}$.

A seguir, as abordagens serão apresentadas com mais detalhes. A ordem de apresentação segue a ordem cronológica de surgimento delas.

\subsubsection{Enfoque das elasticidades}

No enfoque das elasticidades o impacto de uma desvalorização cambial sobre o saldo da balança comercial, expresso em moeda estrangeira, depende das elasticidades-preço da oferta e da demanda de exportações e importações.

Segundo Williamsom (1989, p. 143), partindo de uma situação inicial de equilibrio, a condição Marshall-Lerner, necessária e suficiente para que uma desvalorização cambial melhore o saldo comercial, $\mathrm{e}^{21}$ :

\footnotetext{
${ }^{20}$ Meade, J. The Theory of International Economic Policy, v.1: Balance of Pauments. London: Oxford University Press, 1951.

${ }^{21}$ Ver Sodersten (1979, p. 273-274) para uma derivação completa da condição Marshall-Lerner.
} 
$\left[\frac{E x \cdot(N x-1)}{E x+N x}+\frac{N m \cdot(E m+1)}{E m+N m}\right]>0$

em que:

$E x$ = elasticidade-preço da oferta de exportação (elasticidade-preço da oferta de exportação de produtos do país considerado);

$N x$ = elasticidade-preço da demanda de exportação (elasticidade-preço da demanda de importação do resto do mundo pelos produtos do país considerado);

$E m$ = elasticidade-preço da oferta de importação (elasticidade-preço da oferta de exportação de produtos do resto do mundo); e,

$\mathrm{Nm}$ = elasticidade-preço da demanda de importação (elasticidade-preço da demanda de importação do país considerado pelos produtos do resto do mundo).

As elasticidades têm as seguintes definições:

$$
\begin{array}{ll}
E x=\frac{d x}{d P x} \frac{P x}{x} & N x=-\frac{d x}{d P x}{ }^{*} \frac{P x}{x} \\
E m=\frac{d m{ }^{*} P m^{*}}{d P m^{*} m} & N m=-\frac{d m}{d P m} \frac{P m}{m}
\end{array}
$$

em que:

$x$ e $m$ são o volume das exportações e importações, respectivamente;

$P x$ e $P m$ são os preços das exportações e importações, convertidos em moeda doméstica pela taxa nominal de câmbio $(e)$. Isto é, $P x=e P x^{*}$ e $P m=e P m^{*}$. Desse modo, segue que $P x^{*}$ e $P m^{*}$ são, respectivamente, os preços das exportações e importações expressos em moeda externa.

Portanto, $\mathrm{Nx}$ e Em são definidas em preços externos, enquanto $E x$ e $\mathrm{Nm}$ são definidas em preços domésticos. Deve-se, ainda, atentar para o fato de que as 
elasticidades-preço da demanda estão definidas de maneira que serão, normalmente, positivas.

A condição Marshall-Lerner (1) não será satisfeita se as demandas por exportações e importações forem inelásticas. Para verificar isto, basta tomar o limite da expressão (1) com as referidas elasticidades tendendo para zero (isto é, $\mathrm{Nx}, \mathrm{Nm} \rightarrow 0$ ). Nestas condições, a balança comercial sempre piora após uma desvalorização cambial.

Para avaliar os efeitos esperados de uma desvalorização cambial sobre a balança comercial de um "país pequeno", a abordagem das elasticidades assume que as elasticidades-preço da demanda de exportação, $N x$, e da oferta de importação, Em, defrontadas pelo país frente ao mercado internacional, tendem ao infinito (isto é, $N x, E m \rightarrow \infty)$.

Tomando o limite da expressão (1), com as elasticidades de demanda de exportação, $N x$, e de oferta de importação, $E m$, tendendo para infinito $(N x, E m \rightarrow \infty)$, encontra-se a condição para que a desvalorização cambial melhore o saldo comercial de um "país pequeno". Algebricamente, tem-se o seguinte resultado (ver o apêndice):

$$
(E x+N m)>0
$$

isto é, a soma das elasticidades da oferta de exportação, Ex, e de demanda de importação, $\mathrm{Nm}$, deve ser positiva. Tendo em vista a maneira como as elasticidades são definidas, conclui-se que a balança comercial de um "país pequeno" normalmente melhora com uma desvalorização cambial.

Um segundo caso que tem despertado interesse na literatura especializada é aquele que estuda o efeito de uma desvalorização cambial sobre a balança comercial de um país, quando as elasticidades de oferta de exportação, $E x$, e de oferta de importação, $E m$, tendem ao infinito $(E x, E m \rightarrow \infty)$.

Nesta situação, o limite da expressão (1), com as elasticidades de oferta de exportação e importação tendendo para infinito $(E x, E m \rightarrow \infty)$, resulta em (ver o apêndice): 
ou seja, a soma das elasticidades de demanda por exportações, $N x$, e importações domésticas, $N m$, deve exceder à unidade para que uma desvalorização cambial produza um efeito positivo sobre o saldo da balança comercial. Esta condição também é freqüentemente mencionada na literatura especializada como a condição de MarshallLerner.

A abordagem das elasticidades supõe que uma desvalorização cambial deve induzir uma queda nos termos de troca do país que desvalorizou sua moeda, a menos no caso de "país pequeno", em que os termos de troca independem das políticas internas $^{22}$. Isto é, a desvalorização cambial deve produzir uma redução dos preços, em moeda externa, das exportações do país, comparativamente aos preços de suas importações. Em resposta a este movimento de preços relativos, as quantidades exportadas devem aumentar e as quantidades importadas devem diminuir, contribuindo para melhorar o saldo.

Segundo Williamson (1989, p. 148), a condição suficiente para que uma desvalorização cambial conduza a uma queda nos termos de troca do país que desvalorizou sua moeda é que o produto das elasticidades da oferta $(E x \cdot E m)$ seja maior do que o produto das elasticidades da demanda $(\mathrm{Nx} \cdot \mathrm{Nm})$. Essa condição é assegurada quando as elasticidades de oferta de exportação, $E x$, e de oferta de importação, $E m$, tendem ao infinito $(E x, E m \rightarrow \infty)$, conforme foi assumido na derivação da equação (3).

A abordagem das elasticidades tem sido alvo de muitas críticas. A principal delas consiste no fato dos resultados de uma desvalorização cambial sobre o saldo da balança comercial serem derivados dentro de um enfoque de equilíbrio parcial e não geral (ver, por exemplo, Clement, Pfister \& Rothwell,1967, p. 284-7; e, Sodersten, 1979, p. 275). As elasticidades consideradas refletem ajustamentos parciais de curto

\footnotetext{
${ }^{22}$ Se o país é pequeno em relação ao mercado internacional, o volume de suas importações e exportações representa uma pequena parcela do comércio internacional total, não podendo, portanto, afetar os preços em moeda externa dos produtos transacionados. Assim sendo, os preços de mercado são determinados em função da oferta e demanda totais e, a estes preços, pressupõe a abordagem das elasticidades, o país pode comprar e vender a quantidade que desejar, ceteris paribus.
} 
prazo. O efeito renda, a possibilidade de variação no nível geral de preços e os aspectos monetários de uma desvalorização cambial, dentre outros fatores, não foram notados ou simplesmente foram ignorados na formulação da abordagem tradicional do enfoque das elasticidades.

Outras versões da abordagem das elasticidades surgiram com o propósito de considerar as repercussões de uma desvalorização cambial sobre a renda e o nível geral de preços. Dentre elas, podem-se citar o trabalho de Harberger (1950) e, segundo o mesmo autor, os trabalhos de Brown e Robinson ${ }^{23}$.

Brown e Robinson, citados por Harberger (1950, p. 51), afirmam que o efeito renda age apenas no sentido de diminuir a magnitude absoluta do efeito da desvalorização cambial sobre o saldo da balança comercial, não introduzindo nenhuma mudança no valor crítico da expressão (3), que é necessária para que a desvalorização melhore o saldo comercial.

Para Harberger, isso não é tudo o que acontece, sugerindo que o valor crítico estabelecido pela condição de Marshall-Lerner, partindo de uma situação inicial de equilibrio na balança comercial, não pode mais ser a unidade, como ocorre nos casos em que a renda doméstica é mantida fixa e as elasticidades de oferta são infinitas. A análise de Harberger parte de um modelo keynesiano no qual a demanda por importações está diretamente relacionada com o nível de renda. Portanto, existe a possibilidade de um aumento na renda produzir um déficit na balança comercial do país que desvalorizou sua moeda, se o efeito-renda for maior que o efeito-preço. Desse modo, torna-se necessário investigar se a renda doméstica em termos da renda do resto do mundo aumenta, diminui ou permanece inalterada após a desvalorização cambial.

Harberger alerta para o fato de que uma redução ou uma variação proporcional na renda doméstica em termos da renda do resto do mundo, induzida pela desvalorização da moeda doméstica, é pouco provável. Assim, de modo geral, quando se

\footnotetext{
${ }^{23}$ Brown, A. J. Trade Balances and Exchange Stability. Oxford Economic Papers, n. 6, april, 1942, p. 64-65; e, Robinson, J. Essays in the Theory of Employment. 2 ed. Oxford: Basil Blackwell, 1947. Uma exaustiva relação de trabalhos que contribuiram neste sentido pode ser encontrada em Clemente, Pfister \& Rothwell (1969, p. 287-8).
} 
considera a possibilidade de variação na renda, a soma das elasticidades de demanda por exportação e importação deve ser maior que quando a renda é mantida fixa.

Em que pese os ajustamentos feitos para considerar o efeito renda induzido por uma desvalorização cambial sobre o saldo da balança comercial, as novas versões da abordagem das elasticidades continuam por definir as elasticidades em termos de equilíbrio parcial (Clement, Pfister \& Rothwell,1967, p. 288).

Finalmente, ainda de acordo com Clement, Pfister \& Rothwell (1967, p. 302), uma análise cuidadosa dos efeitos de uma desvalorização sobre a balança comercial, dentro de uma perspectiva da abordagem das elasticidades, permite concluir que não é certo, nem universalmente válido, que uma desvalorização cambial produza um resultado positivo sobre a balança comercial. Isto porque a condição Marshall-Lerner não pode ser assegurada a priori, uma vez que as elasticidades podem variar com o tempo.

\subsubsection{Enfoque da absorção}

Como visto anteriormente, o efeito renda é ignorado na abordagem tradicional das elasticidades, uma vez que a análise é conduzida sob uma condição de renda constante. Na versão proposta por Harberger (1950), o efeito renda, induzido por uma desvalorização cambial, requer uma redução na renda real do país que desvalorizou sua moeda relativamente à renda do resto do mundo, para que a desvalorização produza um efeito positivo sobre o saldo da balança comercial. A redução na renda do país que desvalorizou a moeda deve reduzir a demanda de importações.

Alternativamente, o enfoque da absorção ressalta que a desvalorização cambial deve gerar um maior excedente exportável para que o saldo comercial melhore. Isto não implica, necessariamente, que a renda do país deva diminuir.

A abordagem da absorção parte de uma igualdade onde a conta corrente $(C A)$ - ou a balança comercial $(T B)$, se as transações com serviços e as transferências unilaterais estão equilibradas - é igual à diferença entre a produção nacional ${ }^{24}(Y)$ e a

\footnotetext{
${ }^{24}$ Por simplificação, Alexander (1952) assume que a produção deve se igualar à renda. Assim sendo, os termos renda e produção são utilizados ao longo do texto de forma equivalente.
} 
absorção doméstica $(A)$, nas formas de consumo do setor privado, investimento do setor privado e gastos do governo. Ou seja ${ }^{25}$ :

$T B=Y-A$

Desse modo, se o produto $(Y)$ excede a absorção doméstica $(A)$, o saldo da balança comercial $(T B)$ será positivo. Se o produto é inferior à absorção doméstica, o saldo será negativo. Portanto, a desvalorização deve aumentar o excedente do produto (renda), $Y$, sobre a absorção doméstica, $A$, para que produza um efeito positivo sobre o saldo da balança comercial.

As variações no saldo da balança comercial podem ser expressas do seguinte modo:

$\Delta T B=\Delta Y-\Delta A$

É preciso investigar como a desvalorização cambial afeta o produto (renda) e a absorção doméstica de bens da economia como um todo para avaliar o efeito de uma desvalorização cambial sobre o saldo da balança comercial.

Alexander (1952) examinou o impacto de uma desvalorização cambial sobre a absorção a partir da seguinte formulação:

$\Delta A=\mathrm{c} \Delta Y+d$

em que:

${ }^{25}$ Adota-se a seguinte igualdade entre produto (renda) e dispêndio:

$Y=C+I+G+X-M$

onde $Y=$ produto (renda), $C$ = consumo do setor privado, $I=$ investimento do setor privado: $G=$ gastos do governo, $X=$ exportações de bens e serviços e $M=$ importações de bens e serviços.

Supondo equilibrio nas transações com serviços e nos donativos, e considerando $T B$ (saldo da balança comercial $=X-M$ ) e $A$ (absorção doméstica $=C+I+G$ ), temos: $Y=A+T B$ ou $T B=Y-A$. 
$\Delta A=$ variação na absorção doméstica de bens;

$\mathrm{c} \Delta Y=$ mudança induzida na absorção por variações na renda após a desvalorização;

$\mathrm{c}=$ propensão marginal a gastar (igual à soma das propensões a consumir, a investir e a gastar por parte do governo); e,

$d=$ o efeito direto de uma desvalorização sobre a absorção.

A mudança total no saldo da balança comercial após uma desvalorização cambial pode ser determinada substituindo a relação funcional (6) na igualdade fundamental (5). Obtém-se:

$\Delta T B=(1-\mathrm{c}) \Delta Y-d$

A partir desta formulação (7), Alexander procurou responder a três questões: como a desvalorização afeta a renda (ou produto)? Como uma variação no nivel de renda afeta a absorção doméstica? E, finalmente, como a desvalorização afeta diretamente a absorção a um dado nivel de renda?

Segundo Alexander, uma desvalorização cambial pode afetar a renda por meio de dois efeitos: recursos ociosos e termos de troca.

\subsubsection{Efeito recursos ociosos}

O efeito recursos ociosos está associado com o incremento das exportações do pais e o aumento da produção substituta de importações, que, através do efeito multiplicador da renda em uma economia aberta, resulta em um aumento da renda nacional.

A magnitude do efeito da desvalorização cambial sobre a renda depende da extensão em que um aumento na produção de bens pode ser conseguido sem ocasionar uma aceleração inflacionária, o que depende de quão próximo se encontra o nível de atividade econômica do país em relação ao nível de pleno emprego da economia. 
Deve-se, também, observar até que ponto a demanda externa pode absorver as quantidades adicionais de bens exportáveis produzidos pelo país que desvalorizou sua moeda.

Além do constatado acima, a relação funcional (7) permite-nos verificar que, para a desvalorização ter um efeito positivo sobre o saldo da balança comercial, torna-se necessário que, além da existência de recursos ociosos, a propensão marginal a gastar seja menor que a unidade. Isto, entretanto, não pode ser assegurado a priori, enfatiza Alexander (1952, p.267), ao menos no curto prazo.

Se a economia estiver abaixo do pleno emprego e a propensão marginal a gastar for menor que um, a desvalorização cambial como um instrumento para melhorar o saldo das contas externas torna-se mais atrativa, uma vez que exerce efeitos positivos sobre o nível de produção e emprego. Portanto, estando a economia em nível de pleno emprego, o efeito recursos ociosos, claramente, não existe, mesmo se a propensão marginal a gastar for menor que a unidade.

\subsubsection{Efeito termos de troca}

Um outro efeito através do qual uma desvalorização cambial pode desencadear uma mudança no nível de renda se dá mediante a alteração nos termos de troca do país com o resto do mundo, medida pela relação entre os preços de suas exportações $\left(P x^{*}\right)$ e importações $\left(\mathrm{Pm}^{*}\right)$, ambos cotados em moedas estrangeiras. $\mathrm{O}$ argumento parte da suposição de a desvalorização cambial reduzir o preço das exportações do país, comparativamente ao preço de suas importações, implicando uma deterioração nos termos de troca e em um declínio na renda nacional real medida em moedas estrangeiras ${ }^{26}$. A razão para tal reside no fato do país ser mais especializado em suas exportações que em suas importações, tornando-as, portanto, mais sujeitas aos efeitos de uma mudança na taxa de câmbio.

\footnotetext{
${ }^{26}$ Segundo Williamson $(1989$, p.148) a condição suficiente para que uma desvalorização cambial conduza a uma piora nos termos de troca do país que desvalorizou sua moeda é que o produto das elasticidades da oferta $(E x \cdot E m)$ seja maior do que o produto das elasticidades da demanda $(\mathrm{Nx} \cdot \mathrm{Nm})$.
} 
Se uma deterioração nos termos de troca tem um efeito negativo sobre o nível de renda e a propensão marginal a gastar é menor que a unidade, então uma deterioração nos termos de troca, induzida por uma desvalorização cambial, também implica uma deterioração no equilíbrio externo (Alexander, 1952). Isto decorre do fato de a redução induzida na absorção, com uma propensão marginal a gastar menor que a unidade, ser proporcionalmente menor que a redução causada na renda.

Ainda segundo Alexander (1952), o efeito adverso de uma deterioração dos termos de troca sobre a renda somente terá um efeito positivo sobre as contas externas do país se a propensão marginal a gastar for maior que a unidade, o que constitui uma imposição contrária àquela exigida pelo efeito recursos ociosos. Isto porque, com uma propensão marginal a gastar maior que a unidade, uma redução na renda causará uma redução mais que proporcional na despesa.

Finalmente, Alexander (1952, p. 269) resume da seguinte forma o efeito líquido agregado (recursos ociosos e termos de troca) de uma variação na renda, induzida por uma desvalorização cambial, sobre o equilíbrio externo do país:

'Os efeitos renda agregada podem então ser expressados como (1- c) multiplicado pela variação da renda. Essa variação na renda terá dois componentes: um, supostamente positivo, é o efeito recursos ociosos, i.e., o incremento da produção estimulado pela desvalorização. $O$ outro, supostamente negativo, é o efeito sobre a renda da variação nos termos de troca. A variação resultante na renda, $\Delta Y$, induzirá uma variação na absorção, $\mathrm{c} \Delta Y$, desse modo, a variação resultante na balança comercial em decorrência de uma variação na renda será igual a $\Delta Y-\mathrm{c} \Delta Y$ ou $(1-\mathrm{c}) \Delta Y . "$

\subsubsection{Efeito direto de uma desvalorização cambial}

Em uma situação de pleno emprego, a principal força indutora de uma melhora nas contas externas do país decorre do efeito direto de uma desvalorização sobre a absorção, representado pelo termo d na expressão (6), ver Alexander (1952). Esse efeito agrega as alterações observadas na absorção doméstica que não são associadas 
com as variações no nivel de renda real. A análise é conduzida partindo-se da suposição de que a economia do país encontra-se operando ao nível de pleno emprego, portanto, sem capacidade ociosa, e a oferta de importações e a demanda de exportações, defrontadas pelo país em suas transações comerciais com o resto do mundo, são perfeitamente elásticas. Desse modo, os termos de troca podem ser considerados como dados.

Numa situação de pleno emprego, uma desvalorização cambial tende a pressionar o nível geral de preços. Se o país é pequeno, duas forças contribuem para que isso ocorra: inexistência de capacidade ociosa para responder ao incremento da demanda por bens domésticos substitutos de importações e aumento dos preços, em moeda doméstica, dos bens comercializáveis internacionalmente (bens exportáveis e importáveis).

O efeito direto de uma desvalorização cambial sobre a absorção opera quando uma elevação no nível geral de preços, induzida pela desvalorização, inibe o consumo, o investimento e os gastos do governo. De acordo com Alexander (1952) são três os mecanismos principais através dos quais o efeito direto de uma desvalorização sobre a absorção pode operar: saldo monetário retido, ilusão monetária e redistribuição de renda.

Supondo que a inflação induzida pela desvalorização cambial não seja acompanhada de um aumento em igual proporção na oferta nominal de moeda, então uma elevação no nível geral de preços implica uma redução na oferta real de moeda. O efeito saldo monetário retido atua quando, na tentativa de restabelecer o nível inicial de encaixes reais, os residentes do país reduzem o dispêndio ou vendem ativos. Se forem vendidos ativos que rendem juros, isto deve causar uma declínio no preço dos ativos e uma elevação nas taxas de juros, o que, segundo a tradição keynesiana, inibiria o investimento e, provavelmente, o consumo, reduzindo, assim, o dispêndio doméstico.

O efeito ilusão monetária decorre da decisão dos indivíduos de gastarem menos após uma elevação no nível geral de preços, mesmo com o nível de renda nominal tendo aumentado na mesma proporção. A redução na absorção doméstica induzida pelo efeito ilusão monetária deve ajudar a melhorar o saldo da balança comercial. 
Finalmente, o efeito redistribuição de renda ocorre quando o aumento no nível geral de preços transfere renda de grupos que recebem renda fixa para grupos que podem indexar seus recebimentos ao nível de preços. Se a propensão marginal a gastar dos grupos que tiveram suas rendas aumentadas for menor que a dos grupos que perderam renda, então a desvalorização da moeda deve melhorar as contas externas do país.

A defasagem da evolução dos salários em relação à evolução do nível geral de preços constitui um bom exemplo desse tipo de redistribuição de renda, uma vez que pode transferir renda dos empregados para os empregadores, aumentando a relação lucro/salário. Não obstante, como a absorção inclui tanto o consumo quanto o investimento, não se pode assegurar a priori que a transferência de renda a favor dos lucros reduza a absorção doméstica e, portanto, melhore as contas externas do país.

Alexander conclui dizendo que os efeitos diretos da desvalorização sobre a absorção tendem a ser transitórios e não-proporcionais. Transitórios porque o efeito saldo monetário retido pode ser amortecido, ou até anulado, se a oferta nominal de moeda responder ao aumento da demanda por encaixes nominais. Adicionalmente, os efeitos da redistribuição de renda dependem da existência de defasagens contratuais em relação ao nível geral de preços.

A não-proporcionalidade de alguns efeitos encontra-se associada, por exemplo, com a percentagem da desvalorização e seu impacto sobre a ilusão monetária e sobre a inércia salarial. Uma pequena desvalorização da moeda doméstica pode contribuir positivamente com os efeitos ilusão monetária e redistribuição de renda. Não obstante, uma grande desvalorização pode quebrar ou mudar a dinâmica da inércia salarial, bem como abalar a ilusão monetária.

De modo geral, conclui Alexander, os efeitos diretos de uma desvalorização sobre a absorção doméstica são incertos, uma vez que dependem da combinação de várias forças mencionadas acima, que, como vimos, podem ser transitórias e não-proporcionais. Assim, a pleno emprego, o efeito de uma desvalorização sobre a absorção doméstica tende a ser fraco. Portanto, continua o autor, em tal situação, 
é preferivel atuar diretamente sobre a absorção através de políticas monetária e creditícia, desde que não tenham um efeito adverso sobre a renda e emprego.

As principais críticas à abordagem da absorção concentram-se em dois pontos $^{27}$. Primeiro, a abordagem da absorção assume explicitamente uma relação causal da absorção para o saldo da balança comercial. Deixando de analisar como as variações na absorção afetam o nível de renda. Desse modo, é negligenciada a possibilidade de uma menor absorção conduzir a um menor nível de renda, antes que a uma melhora no saldo da balança comercial.

Outra crítica direciona-se para o fato de que a abordagem da absorção não trata adequadamente do papel dos preços relativos no processo de ajustamento da balança comercial. Naturalmente, após uma desvalorização cambial, os preços dos bens domésticos aumentam menos que os preços dos bens comercializáveis internacionalmente, em moeda $\operatorname{local}^{28}$. $\mathrm{O}$ ajustamento em preços relativos constitui, portanto, o mecanismo indutor da realocação de recursos em direção ao setor mais rentável, tendendo a aumentar o excedente exportável. Esse efeito, no entanto, tem sido ignorado na abordagem da absorção. A redução na absorção doméstica induzida por uma desvalorização cambial admite implicitamente que alguma mudança em preços relativos deve ocorrer

Ademais, a possibilidade de que a propensão marginal a gastar seja maior que a unidade, conforme enfatiza Alexander, só pode ocorrer no curto prazo. Se a propensão marginal a gastar for maior que a unidade, a economia não converge para o equilíbrio. Essa constatação não é considerada na abordagem da absorção.

\footnotetext{
${ }^{27}$ Para maiores detalhes ver Clement, Pfister \& Rothwell (1967, p. 316-322).

${ }^{28}$ Isto ocorre numa economia onde os preços domésticos não estão indexados à taxa de câmbio.
} 


\subsubsection{Modelo IS-LM-BP ${ }^{29}$}

O modelo IS-LM-BP, também conhecido como modelo keynesiano de economia aberta, resultou da combinação de duas abordagens básicas de ajustamento da balança comercial: o enfoque das elasticidades e o enfoque da absorção.

Para explicar o ajustamento do balanço de pagamentos, o modelo IS-LMBP incorporou as variáveis preço (do enfoque das elasticidades) e as variáveis renda (do enfoque da absorção), acrescentando ainda os fluxos financeiros que ocorrem entre as nações.

A equação geral do modelo IS-LM-BP de determinação do saldo do balanço de pagamentos tem a seguinte especificação:

$B P=(X-M)-F-R$

em que BP é o saldo do balanço de pagamentos, $(X-M)$ são as exportações líquidas de bens e serviços (diferença entre as exportações, $\mathrm{X}$, e as importações, $\mathrm{M}$ ), $\mathrm{F}$ é a saída líquida de capital privado e $\mathrm{R}$ são as transferências a estrangeiros feitas pelo governo e pelo setor privado.

Para o propósito da presente pesquisa, que é estimar uma equação para o saldo da balança comercial, os componentes F e R da equação (8) podem ser ignorados, obtendo, assim, uma equação de determinação da conta corrente. Adicionalmente, considerando que as transações com serviços também estão equilibradas, a equação (8) transforma-se em uma equação de determinação do saldo da balança comercial. Assim procedendo, têm-se:

$\mathrm{TB}=(\mathrm{X}-\mathrm{M})$

\footnotetext{
${ }^{29}$ Para uma exposição mais detalhada do modelo IS-LM-BP consultar os livros textos de macroeconomia de Branson \& Litvack (1978, p. 341-363) e Dornbusch (1980) e Dornbusch \& Fischer (1991). A referência completa dos trabalhos mencionados segue na seção bibliográfica.
} 
Tanto as exportações, $\mathrm{X}$, quanto as importações, $\mathrm{M}$, são componentes da demanda agregada de bens e serviços, o lado real da economia, e integram a curva IS que estabelece a condição de equilíbrio no mercado de bens e serviços. No modelo IS-LM-BP a oferta de moeda entra afetando a taxa de juros da economia, que por sua vez exerce influência sobre os investimentos privados e o fluxo de capitais entre o país e o resto do mundo. As variáveis investimento privado e fluxo de capitais não são de interesse para a presente pesquisa, que busca investigar os determinantes do saldo da balança comercial de produtos agrícolas e agroindustriais. Por definição, o saldo da balança comercial é o resultado líquido das transações comerciais de mercadorias do país com o resto do mundo

Portanto, considera-se apenas parte do modelo IS-LM-BP. Por essa razão, o modelo aqui analisado passa a ser denominado de IS-TB, com TB representando a balança comercial ${ }^{30}$. Procedimento similar foi adotado por Liu et al (1993) ao analisar os impactos de variáveis macroeconômicas domésticas e externas sobre as exportações de carnes dos Estados Unidos.

A análise que se segue é aplicada para uma economia que mantém um regime de taxa de câmbio fixa ou administrada.

Para um dado nível de preços dos bens competitivos com os nacionais, o valor real das exportações, $x$, expresso em moeda doméstica, no modelo IS-TB passa a ser função dos preços dos bens do país exportador, p, da taxa de câmbio real, $e$, e do nível de renda real externa, y*. Ou seja:

$x=x\left(\mathrm{p}, e, \mathrm{y}^{*}\right)$

com a taxa de câmbio, $e$, definida como a quantidade de moeda doméstica trocada por uma unidade de moeda externa.

\footnotetext{
${ }^{30}$ A denominação adotada é compativel com a utilizada por Rivera-Batiz \& Rivera-Batiz (1994, p. 334), qual seja, demanda agregada e comércio internacional. Entretanto, a demanda agregada também inclui o mercado monetário, por essa razão optou-se pela denominação IS-TB, uma vez que a IS reflete apenas a demanda agregada no mercado de bens e serviços.
} 
Em condições ceteris paribus um aumento nos preços dos bens domésticos elevará o preço externo dos bens que o país exporta (caso o país seja grande frente ao mercado internacional), afetando negativamente a competitividade de suas exportações (ver Branson \& Litvack, 1978, p. 344). Contrariamente, uma desvalorização real da taxa de câmbio, por tornar as exportações do país mais competitivas, pode produzir um efeito positivo sobre as exportações ${ }^{31}$. Por fim, um aumento no nivel de renda externa deve aumentar a demanda por exportações do país considerado.

O valor real das importações expresso em moeda doméstica, $m_{r e}$, resultante do produto entre o valor em moeda externa das importações, $m$, e a taxa de câmbio real, $e$, depende do nível de renda real doméstica (y), da taxa de câmbio real $(e) \mathrm{e}$ dos preços externos dos bens que competem com os nacionais $\left(\mathrm{p}^{*}\right)$. Em condições ceteris paribus um aumento no nivel de renda doméstica aumenta a demanda por importações. Para um dado nivel de preços dos produtos concorrentes, uma valorização cambial reduz o preço desses produtos em moeda doméstica e, consequentemente, induz um aumento das importações. Uma elevação nos preços dos bens domésticos, p, tende a torná-los mais caros que os similares disponiveis externamente, o que deve contribuir para elevar as importações. Assim, pode-se escrever a função importação do seguinte modo:

$m_{r e}=e \cdot m\left(\mathrm{y}, e, \mathrm{p}, \mathrm{p}^{*}\right)$

Após substituir (10) e (11) em (9) obtém-se a expressão completa para o saldo da balança comercial, em termos reais, no modelo IS-TB:

$\mathrm{tb}=x\left(\mathrm{p}, e, \mathrm{y}^{*}\right)-e \cdot m\left(\mathrm{y}, e, \mathrm{p}, \mathrm{p}^{*}\right)$

Uma desvalorização real da taxa de câmbio, $e$, e um aumento no nível de renda externa, $y^{*}$, produzem uma melhora no saldo real da balança comercial, tb, por

\footnotetext{
${ }^{31}$ Deve-se atentar para o fato de que a variável de política econômica é a taxa nominal de câmbio, de modo que as alterações praticadas pelo Banco Central na taxa nominal visam afetar a taxa real.
} 
aumentar as exportações. A desvalorização real da taxa de câmbio também tende a produzir um efeito positivo sobre o saldo da balança comercial por tornar mais caras, em moeda doméstica, as importações.

Por outro lado, uma elevação no nível de renda interna e preços dos bens domésticos diminui o saldo real da balança comercial, por aumentarem as importações e, também, pelo fato do aumento dos preços dos bens domésticos diminuirem as exportações.

Para determinar os efeitos de uma variação na taxa de câmbio real sobre o saldo da balança comercial, o modelo IS-TB pressupõe que uma alteração na taxa de câmbio real produz uma mudança nos termos de troca, a menos no caso de "país pequeno", em que os termos de troca independem das políticas internas. Por exemplo, uma desvalorização real do câmbio deve produzir uma redução, em moeda externa, no preço das exportações do país (p/e), comparativamente ao preço de suas importações (p*). Em resposta a este movimento de preços relativos, as quantidades exportadas devem aumentar e as quantidades importadas devem diminuir, ajudando a melhorar o saldo comercial. Como enfatizado na abordagem das elasticidades, a estabilidade deste resultado depende de a condição Marshall-Lerner ser satisfeita.

Tratando-se de "país pequeno", os preços dos bens que ele exporta são determinados pelas condições de oferta e demanda totais no mercado internacional e, a esses preços, o país pode vender a quantidade que desejar (enquanto houver demanda). Nesta situação, uma desvalorização cambial não altera os termos de troca (expressos em moeda externa), mas melhora o saldo da balança comercial porque o volume exportado tende a aumentar (em decorrência da maior receita, em moeda doméstica, por unidade adicional exportada) e o volume importado deve diminuir (em virtude do aumento, em moeda doméstica, dos preços das importações).

Ademais, tratando-se de "país pequeno", uma elevação exógena nos preços externos dos bens que ele exporta altera os termos de troca, afetando positivamente o saldo da balança comercial. A estabilidade desse resultado depende de a curva de demanda defrontada por um "país pequeno" no mercado internacional ser, de fato, perfeitamente elástica. 
Embora o modelo IS-TB de determinação do saldo da balança comercial seja mais completo do que as abordagens das elasticidades e da absorção, por levar em consideração maior número de variáveis e relações econômicas, ainda continua sendo um modelo de ajustamento mais aplicado a situações de curto prazo. A possibilidade de uma elevação no nível de renda doméstica resultar em uma melhora no saldo da balança comercial, a longo prazo, não é contemplada.

\subsubsection{Comparação entre a abordagem das elasticidades, a abordagem da absorção e o modelo IS-TB}

As abordagens das elasticidades e da absorção e o modelo IS-TB estabelecem relações estruturais diretas entre o saldo da balança comercial, que aparece como a variável dependente da equação, e um conjunto de variáveis. As relações encontradas refletem ajustamentos parciais entre as variáveis consideradas e o saldo comercial. Apresentam-se no Quadro 3, em resumo, as relações (diretas) gerais, mais prováveis, estabecidas por cada abordagem.

Quadro 3. Relações, mais prováveis, entre o saldo da balança comercial e um conjunto de variáveis, segundo a abordagem das elasticidades, a abordagem da absorção e o modelo IS-TB para o caso de um "país pequeno" frente ao mercado internacional.

\begin{tabular}{|l|ccc|}
\hline Variável & \multicolumn{3}{c|}{ Abordagem } \\
\cline { 2 - 4 } & Das elasticidades & Da absorção & Modelo IS-TB \\
\hline Taxa de câmbio & positiva & positiva & positiva \\
Termos de troca $^{1}$ & positiva & não contempla & positiva \\
Renda interna & não contempla & positiva & negativa \\
Renda externa & não contempla & não contempla & positiva \\
\hline
\end{tabular}

Considera-se uma elevação exógena nos termos de troca.

Além das relações acima apresentadas, algumas relações indiretas podem ocorrer, caso da taxa de juros e saldo da balança comercial. Um aumento na taxa de juros 
inibe os investimentos produtivos, diminuindo a absorção doméstica e o nível de renda da economia. Portanto, as alterações no nível de renda doméstica (variável já contemplada no modelo econométrico a ser estimado, ver item 5.3 do capítulo metodológico) deve também captar os efeitos indiretos da taxa de juros sobre o saldo da balança comercial.

\subsection{Equação básica do saldo da balança comercial}

No item 4.1 deste capítulo foram apresentadas as implicações de uma desvalorização cambial sobre o saldo da balança comercial segundo a abordagem das elasticidades, a abordagem da absorção e o modelo IS-TB, identificando as variáveis fundamentais a cada modelo e suas relações diretas com o processo de ajustamento da balança comercial.

O próximo passo é definir uma equação para o saldo da balança comercial brasileira de produtos agrícolas e agroindustriais. Para tanto, o referencial teórico, apresentado anteriormente, e os trabalhos empíricos, que tratam do ajustamento da balança comercial, são utilizados para auxiliar no processo de seleção das variáveis.

Freqüentemente, as variáveis consideradas nas estimações de equações para o saldo da balança comercial, no Brasil e em outros países, são aquelas contempladas nas abordagens das elasticidades, da absorção e no modelo IS-TB ${ }^{32}$. Entre elas destacam-se: i) o nível de atividade doméstica, medido pelo Produto Interno Bruto ou pelo Produto Nacional Bruto; ii) o nível de atividade externa, mensurado como uma média ponderada do Produto Nacional Bruto dos principais parceiros comerciais do país; e, iii) um índice de competitividade de preços, geralmente a taxa de câmbio real e/ou os termos de troca.

Em geral, as equações são especificadas na forma reduzida. Os coeficientes estimados refletem efeitos totais, sendo os sinais a eles associados determinados pelo(s) efeito(s) mais forte(s). Quando aplicada ao Brasil, a função para o saldo da balança comercial apresenta a seguinte especificação:

\footnotetext{
${ }^{32}$ Ver, por exemplo, os trabalhos de Braga \& Rossi (1986); Boucher (1991); Rose (1991); e, Zini Jr (1993), dentre outros.
} 
$\mathrm{ST}=\mathrm{f}(\mathrm{RB}, \mathrm{RW}, e, \mathrm{TT})$

em que,

$\mathrm{ST}=$ saldo da balança comercial; expresso em moeda externa;

$\mathrm{RB}=$ nível de renda interna;

$\mathrm{RW}=$ nível de renda externa;

$e=$ taxa de câmbio real; e,

$\mathrm{TT}=$ termos de troca.

A nomeclatura de algumas variáveis foi alterada para associar a aplicação da função ao caso em estudo. Para fins de estimação, a função (13) ainda pode incluir variáveis binárias para captar fenômenos temporários que afetam o saldo comercial.

Na presente pesquisa são utilizadas as seguintes variáveis: saldo da balança comercial agrícola total; taxa de câmbio efetiva real; termos de troca; níveis de renda interna e externa; e, uma variável de choque para captar os efeitos da geada de 1975 sobre os preços do café no mercado internacional e, consequentemente, sobre o saldo da balança comercial agrícola total.

A seguir, apresentam-se os efeitos esperados das variáveis explicativas sobre o saldo da balança comercial.

\subsubsection{Efeitos esperados de uma desvalorização cambial}

Com base no referencial teórico e nas evidências empíricas para o país, espera-se que uma desvalorização cambial tenha um efeito positivo sobre o saldo da balança comercial de produtos agrícolas e agroindustriais do Brasil. Do lado da abordagem das elasticidades, a suposição é que a condição Marshall-Lerner seja satisfeita. Quanto à abordagem da absorção e ao modelo IS-TB, a hipótese levantada é a de que a desvalorização cambial aumenta o excedente exportável. Isto porque, os preços, em moeda local, dos bens comercializáveis internacionalmente tendem a aumentar e, desse modo, estimular as exportações e, simultaneamente, inibir a absorção doméstica 
dos bens importáveis. A combinação desses dois efeitos deve elevar o saldo da balança comercial agrícola total após a desvalorização da moeda doméstica.

Algumas qualificações devem ser feitas com relação ao efeito esperado da desvalorização cambial sobre o saldo comercial agrícola total a curto prazo. O efeito de uma desvalorização cambial sobre o saldo comercial pode ocorrer com um certo retardamento. Assim, podem-se encontrar, a curto prazo, baixos coeficientes estimados associados à variável taxa de câmbio.

Uma "fraca" relação entre as variações a curto prazo na taxa de câmbio (efeito-preço) e o saldo comercial decorre da defasagem de resposta do comércio internacional (em volume transacionado) a o efeito-preço (Williamson, 1989, p. 145). Esse retardamento, sugere o autor, decorre do fato da maior parte do comércio internacional ocorrer entre parceiros tradicionais. Assim sendo, a troca de parceiros só se justificaria quando os beneficios esperados da desvalorização durassem o suficiente para compensar a troca.

A análise parte de uma situação em que os contratos de exportações ou importações antecedem a entrega do bem transacionado. Juns \& Roh, citados por Braga \& Rossi (1986, p. 148), apontam algumas razões para a existência da defasagem de resposta do saldo comercial às variações na taxa de câmbio, que consideradas em conjunto podem incorporar uma defasagem de até cinco anos, quais sejam: a) retardamento que compreende a variação na taxa de câmbio corrente e o reconhecimento, por parte dos agentes econômicos, de que o preço, induzido por uma variação cambial, realmente mudou; e, b) retardamento econômico, que envolve a decisão de mudar variáveis reais, a recomposição dos estoques, a alteração na produção e tempo de entrega.

Como ressaltado anteriormente, estas são as causas dos baixos coeficientes de elasticidade-preço de curto prazo, freqüentemente, encontrados nas estimativas das equações de comércio exterior. Tratando-se de transações com mercadorias agrícolas e derivadas da agricultura, o componente de retardamento, que decorre do lapso de tempo entre as desvalorizações cambiais e alteração na produção, 
torna-se ainda mais expressivo. Isto porque, a curto prazo, a oferta de produtos agrícolas (insumo para os produtos agroindustriais) pode ser considerada fixa ou quase fixa.

\subsubsection{Efeitos esperados de uma variação nos termos de troca}

Partindo da suposição de que o Brasil é tomador de preços no mercado internacional, para a maioria dos produtos agrícolas e agroindustriais que o país exporta e importa, pode-se considerar os termos de troca como dados ${ }^{33}$. Desse modo, um aumento (exógeno) nos preços externos dos produtos exportados pelo Brasil não implicaria, necessariamente, em uma redução nas quantidades demandadas de exportações do país. Por essa razão, espera-se que um aumento nos termos de troca tenham um efeito positivo sobre o saldo comercial.

\subsubsection{Efeitos esperados de uma variação no nível de renda doméstica}

Associando o nível de renda doméstica com o incremento da demanda por importações, conforme os modelos keynesianos de ajustamento da balança comercial, deve-se esperar uma relação negativa entre o nível de renda e o saldo da balança comercial agrícola total, pelo menos no curto prazo.

Por outro lado, com base na abordagem da absorção, pode-se associar o nível de renda ao nível de produção doméstica e, assim, esperar uma relação positiva (no médio e longo prazos) entre renda e saldo da balança comercial do país, a menos que o crescimento no consumo doméstico seja superior ao observado na renda. Um aumento de consumo superior ao aumento na renda é improvável a longo prazo (pois supõe que a propensão marginal a consumir é maior que um), principalmente tratando-se de produtos agrícolas que são, reconhecidamente, bens de essencial necessidade.

\footnotetext{
${ }^{33}$ Evidências empiricas apontam que pelo menos para alguns produtos o Brasil aparece como tomador de preços no mercado internacional, dentre eles podem ser citados: o café, o açúcar e a amêndoa de castanha de caju. Ver Almeida \& Mesquita, 1995, para maiores esclarecimentos.
} 
Portanto, supondo que um aumento na renda doméstica é acompanhado de um aumento na renda dos setores agrícolas e agroindustriais e que a propensão marginal a consumir bens agrícolas e agroindustriais seja menor que a unidade (mesmo a curto prazo), pode-se esperar uma relação positiva entre renda doméstica e saldo da balança comercial de produtos agrícolas e agroindustriais.

\subsubsection{Efeitos esperados de uma variação no nível de renda externa}

Com base na versão de Harberger para o enfoque das elasticidades, no modelo keynesiano de ajustamento da balança comercial e nas evidências empíricas para o Brasil, espera-se que a renda do resto do mundo esteja positivamente relacionada com o saldo comercial. Ou seja, um incremento no nível de renda do resto do mundo deve aumentar a demanda por exportações brasileiras ou, equivalentemente, deve aumentar a demanda por importações do resto do mundo.

\subsubsection{Efeitos esperados decorrentes de geadas sobre os cafezais do Brasil}

A geada de 1975 provocou elevação nos preços internacionais de café nos anos de 1976 e 1977. Admitindo que a demanda de exportação de café do Brasil seja inelástica (o que, para aquele momento, era o que ocorria), espera-se que a geada tenha provocado uma melhora, naqueles anos, sobre o saldo da balança comercial agrícola total $^{34}$.

Como enfatizado no capítulo 3, a maioria dos trabalhos estimam equações do tipo da expressão (13) utilizando técnicas econométricas tradicionais. Assim procedendo, pode-se encontrar relações espúrias entre a variável dependente e os regressores se essas variáveis não são estacionárias e se a combinação linear entre elas produz um termo de erro não-estacionário.

\footnotetext{
${ }^{34}$ Como o efeito da geada se dá apenas por meio do efeito preço não haveria, a priori, necessidade de uma variável adicional, pois o modelo já inclui os termos de troca. Porém, a inclusão da variável binária foi necessária para tornar as estimativas mais estáveis.
} 
Para não incorrer neste tipo de erro, a presente pesquisa utiliza a análise de co-integração e o modelo de correção de erros para estimar a expressão (13). Essa metodologia e os dados utilizados são apresentados no capítulo seguinte. 


\section{METODOLOGIA}

Inicialmente, apresentam-se os procedimentos econométricos necessários para estimar uma equação com base na expressão (13) segundo a análise de cointregração (item 5.1). Em seguida, definem-se as variáveis empregadas na análise e apresentam-se os dados utilizados (item 5.2). Por fim, resume-se o modelo econométrico a ser estimado (item 5.3).

\subsection{Procedimentos econométricos}

São três as etapas dos procedimentos econométricos utilizados no presente trabalho. A primeira etapa consiste em aplicar testes de raiz unitária para verificar se as séries em análise podem ser consideradas estacionárias. Na segunda etapa determina-se o número de relações de co-integração e estimam-se os vetores de coeficientes destas relações, com a finalidade de determinar os efeitos de longo prazo entre as variáveis selecionadas e o saldo da balança comercial de produtos agrícolas e agroindustriais do Brasil. Finalmente, uma vez aceita a hipótese de co-integração, os efeitos de curto prazo são mensurados a partir de um modelo de correção de erros.

\subsubsection{Teste de raiz unitária}

Um processo auto-regressivo de primeira ordem com raiz unitária e sem nenhum componente determinístico, um passeio aleatório puro, é aquele no qual o coeficiente associado ao regressor é unitário. 
O teste de raiz unitária determina a ordem de integração das séries. Se a ordem de integração é zero, $\mathrm{I}(0)$, a série é dita estacionária. Se a ordem de integração for maior do que zero, [ $\mathrm{I}(1), \mathrm{I}(2), \ldots$.$] , a série não exibe estacionariedade.$

No presente texto, entende-se por estacionariedade de uma série temporal um processo no qual a média e a variância são constantes no tempo e o valor da covariância entre dois períodos de tempo depende somente da defasagem entre os dois períodos de tempo [Gujarati, 1995, p. 713].

Se as séries temporais forem estacionárias, as análises podem ser feitas utilizando o instrumental econométrico convencional (regressões). Não ocorrendo a estacionariedade das séries, o procedimento recomendado na literatura mais recente consiste em utilizar a análise de co-integração, por permitir obter as relações de longo e curto prazos entre as variáveis, sem incorrer no risco de encontrar relações espúrias.

Conforme constatado por Hansen \& Juselius (1995, p. 1), frequentemente, tem-se assumido, erroneamente, que a condição necessária para que séries temporais cointegrem é que elas sejam integradas de mesma ordem. Séries integradas de mesma ordem somente é uma condição necessária para se estabelecer uma relação de cointegração se, e somente se, o sistema envolver apenas duas variáveis. Recentemente, com os novos desenvolvimentos no estudo da co-integração, tornou-se possível estimar relações de co-integração entre séries temporais integradas de diferentes ordens. Contudo, deve-se tomar cuidado com a interpretação dos resultados, atentando-se para o fato de que o número de relações de co-integração cresce com o número de variáveis estacionárias $\mathrm{I}(0)$ incluídas no modelo, com efeito de 1 para 1 (Hansen \& Juselius, 1995, p. 1). As tabelas a serem utilizadas para determinar o número de vetores de co-integração diferem daquelas geradas para o caso mais simples, qual seja, quando todas as variáveis são integradas de ordem um.

Assim sendo, o mais correto seria afirmar que o teste de raiz unitária antecede o emprego da análise de co-integração. Na presente pesquisa, o teste de Dickey Fuller Aumentado (ADF) foi utilizado para testar a ordem de integração de cada série temporal. A escolha desse teste deve-se ao seu extenso uso na literatura especializada. 
Portanto, o primeiro passo da metodologia consiste em realizar teste de raiz unitária de Dickey Fuller Aumentado para cada série tomada individualmente, com base no procedimento seqüencial sugerido por Perron (ver Harris, 1995, p. 31-32). Esse procedimento é recomendado porque em pesquisas aplicadas o verdadeiro processo gerador dos dados é desconhecido.

O procedimento seqüencial de Perron para determinar a ordem de integração de uma série temporal consiste em estimar, pelo método dos mínimos quadrados ordinários, para cada série considerada, um processo auto-regressivo de ordem "p" reparametrizado 35 , fazendo-se uso das equações apresentadas no Quadro 4.

Quadro 4. Seqüência para o teste de raiz unitária ADF utilizando o procedimento seqüencial de Perron.

\begin{tabular}{|lcc|}
\hline Etapa e modelo & Hipótese nula & Teste estatístico \\
\hline (I) $\Delta \mathrm{y}_{\mathrm{t}}=\mu_{c}+\gamma_{\mathrm{c}} \mathrm{t}+\beta_{0} \mathrm{y}_{\mathrm{t}-1}+\sum_{i=1}^{p-1} \beta_{i} \Delta \mathrm{y}_{\mathrm{t}-\mathrm{i}}+\varepsilon_{\mathrm{t}}$ & $\beta_{0}=0$ & $\tau_{\tau}$ \\
(II) $\Delta \mathrm{y}_{\mathrm{t}}=\mu_{c}+\gamma_{c} \mathrm{t}+\beta_{0} \mathrm{y}_{\mathrm{t}-1}+\sum_{i=1}^{p-1} \beta_{i} \Delta \mathrm{y}_{\mathrm{t}-\mathrm{i}}+\varepsilon_{\mathrm{t}}$ & $\beta_{0}=\gamma_{c}=0$ & $\phi_{3}$ \\
(IIa) $\Delta \mathrm{y}_{\mathrm{t}}=\mu_{c}+\gamma_{c} \mathrm{t}+\beta_{0} \mathrm{y}_{\mathrm{t}-1}+\sum_{i=1}^{p-1} \beta_{i} \Delta \mathrm{y}_{\mathrm{t}-\mathrm{i}}+\varepsilon_{\mathrm{t}}$ & $\beta_{0}=0$ & $\mathrm{t}$ \\
(III) $\Delta \mathrm{y}_{\mathrm{t}}=\mu_{c}+\beta_{0} \mathrm{y}_{\mathrm{t}-1}+\sum_{i=1}^{p-1} \beta_{i} \Delta \mathrm{y}_{\mathrm{t}-\mathrm{i}}+\varepsilon_{\mathrm{t}}$ & $\beta_{0}=0$ & \\
(IV) $\Delta \mathrm{y}_{\mathrm{t}}=\mu_{c}+\beta_{0} \mathrm{y}_{\mathrm{t}-1}+\sum_{i=1}^{p-1} \beta_{i} \Delta \mathrm{y}_{\mathrm{t}-\mathrm{i}}+\varepsilon_{\mathrm{t}}$ & $\tau_{0}=\mu_{c}=0$ & $\phi_{1}$ \\
(IVa) $\Delta \mathrm{y}_{\mathrm{t}}=\mu_{c}+\beta_{0} \mathrm{y}_{\mathrm{t}-1}+\sum_{i=1}^{p-1} \beta_{i} \Delta \mathrm{y}_{\mathrm{t}-\mathrm{i}}+\varepsilon_{\mathrm{t}}$ & & $\mathrm{t}$ \\
(V) $\Delta \mathrm{y}_{\mathrm{t}}=\beta_{0} \mathrm{y}_{\mathrm{t}-1}+\sum_{i=1}^{p-1} \beta_{i} \Delta \mathrm{y}_{\mathrm{t}-\mathrm{i}}+\varepsilon_{\mathrm{t}}$ & $\beta_{0}=0$ & $\tau$ \\
\end{tabular}

Fonte: Adaptado de Harris (1995, p. 31).

Nota: O nome de cada teste estatístico é idêntico ao da sua representação. Por exemplo, o teste $\tau_{\tau}$ é chamado tal tal.

${ }^{35}$ A reparametrização consiste em tomar a variável dependente do processo auto-regressivo em primeira diferença. 
Para as equações que aparecem no Quadro 4, têm-se as seguintes definições:

$\Delta y_{t}=$ variável y em primeira diferença $\left(\Delta y_{t}=y_{t}-y_{t-1}\right)$

$\mathrm{y}_{\mathrm{t}-1}=$ variável y defasada de um período;

$\Delta \mathrm{y}_{\mathrm{t}-\mathrm{i}}=$ primeira diferença da variável y defasada de um período $\left(\Delta \mathrm{y}_{\mathrm{t}-\mathrm{i}}=\mathrm{y}_{\mathrm{t}-\mathrm{i}}-\mathrm{y}_{\mathrm{t}-\mathrm{i}-\mathrm{i}}\right)$;

$\mathrm{t}=$ tendência temporal;

$\mu_{c}, \gamma_{c}, \beta_{0}$ e $\beta_{\text {i }}$ são parâmetros a serem estimados; e,

$\varepsilon_{\mathrm{t}}$ é o termo de erro da equação, um ruído branco Gaussiano ${ }^{36}$.

Conforme pode ser constatado em Harris (1995, p. 32), a hipótese nula de raiz unitária é testada partindo-se de uma especificação mais geral para o processo gerador dos dados, indo até a especificação mais restrita. Se a hipótese nula não puder ser rejeitada a partir da especificação mais geral, prossegue-se testando a hipótese nula de uma raiz unitária, modelo a modelo, até se chegar à especificação mais restrita do processo gerador dos dados. A rigor, o teste deve parar quando a hipótese nula de raiz unitária puder ser rejeitada (veja a seqüência no Quadro 4). Deve-se ainda atentar para o fato de que as etapas (IIa) e (IVa) somente serão realizadas se as hipóteses conjuntas em (II) e (IV) forem rejeitadas.

A hipótese subjacente às equações especificadas no Quadro 4 é que o processo gerador dos dados deva ser um processo auto-regressivo de ordem " $p$ " reparametrizado. A especificação mais geral do processo auto-regressivo inclui uma constante e uma tendência temporal, enquanto a especificação mais restrita exclui todos os componentes determinísticos do processo gerador dos dados.

Para saber se a série analisada é estacionária, testa-se a hipótese nula de que a série é integrada de ordem um, denotada por I(1). O teste ADF é aplicado ao coeficiente estimado $\beta_{0}$ associado à variável $\mathrm{y}_{\mathrm{t}-1}$ em cada modelo. Se a hipótese nula de que $\beta_{0}=0$ não puder ser rejeitada, tem-se evidência de que a série exibe raiz unitária,

\footnotetext{
${ }^{36}$ É o termo de erro que tem média zero, variância constante, temporalmente independentes entre si e tem distribuição normal.
} 
sendo, portanto, não-estacionária em nível. Inversamente, se a hipótese nula for rejeitada, isto é, se estimativa de $\beta_{0}$ for estatisticamente menor que zero, então a série em análise é dita estacionária em nível.

A estatística para este teste tem denominação que varia conforme o número de componentes determinísticos incluídos na equação, sendo calculada dividindose o valor do coeficiente estimado $\beta_{0}$ por seu respectivo desvio padrão. Os valores críticos das referidas estatísticas não seguem a distribuição da estatística t usual, tendo sido calculados por simulação de Monte Carlo, em Fuller (1976).

As estatísticas que testam as hipóteses conjuntas são versões da estatística F, que por não apresentarem distribuição padrão recebem outras denominações, variando segundo a hipótese nula conjunta que se deseja testar (veja Quadro 4). A estatística $\phi_{3}$ testa a hipótese (nula) conjunta de que a série em análise pode ser representada por um processo com raiz unitária e sem tendência. Por outro lado, a estatística $\phi_{1}$ testa a hipótese nula de que o processo gerador dos dados possui uma raiz unitária e a média do processo é indeterminada. Os valores críticos tabulados das estatísticas $\phi_{1}$ e $\phi_{3}$ podem ser encontrados em Dickey \& Fuller (1981).

Na prática, o procedimento seqüencial de Perron parte da possibilidade de existência de mais de uma raiz unitária, o que também foi seguido na presente pesquisa. Para detectar ordem de integração maior que um, deve-se aumentar o número de diferenças incluídas nas equações apresentadas no Quadro 4 e decrescer de um o número de defasagens consideradas. O número de diferenças tomadas coincide com o número de ordem de integração que a equação será capaz de detectar. No presente trabalho foram consideradas até duas diferenças, uma vez que é pouco provável que séries econômicas apresentem ordem de integração maior que dois ${ }^{37}$.

Uma das dificuldades na aplicação do teste ADF consiste em determinar o número de diferenças defasadas da variável a ser incluído na equação. Como regra geral, parte-se do princípio de que o número de termos de diferenças defasadas deve ser aquele que torne o termo de erro da equação não-correlacionado serialmente. Vários

\footnotetext{
${ }^{37}$ Ver Harris (1995, p. 37) sobre a forma de especificação das equações.
} 
procedimentos podem ser utilizados em trabalhos empíricos para auxiliar a determinação da ordem de defasagem " $p$ " dos processos auto-regressivos, destacando-se dentre eles os critérios de Schwarz (SC) e Akaike (AIC). Regra geral, os critérios mencionados estabelecem que o número de defasagens a ser incluído é determinado pelo menor valor dos referidos testes.

Como existe a possibilidade de diferentes critérios apontarem para diferentes números de termos de defasagens, tem-se uma dificuldade adicional na escolha do critério a adotar. O procedimento geralmente seguido tem sido o de utilizar um ou mais critérios. Como ainda não ficou estabelecido na literatura qual o melhor critério, no presente trabalho foi utilizado o de Schwarz. Ademais, o critério de Schwars é um dos critérios mais parcimoniosos, o que pode constituir uma vantagem, se se considerar que o tamanho da amostra utilizada é particularmente pequeno.

\subsubsection{Teste de co-integração}

Após verificar a ordem de integração de cada série, o próximo passo consiste em determinar se elas co-integram. Hamilton (1994, p. 571), considerando o caso mais simples de vetores co-integrados, afirma que "um vetor $\mathbf{y}_{\mathrm{t}}(\mathrm{n} \times 1)$ de séries temporais é dito co-integrado se cada série tomada individualmente é integrada de ordem um [ I(1) ], isto é, não-estacionária com raiz unitária, desde que alguma combinação linear das séries $\mathbf{a}^{\prime} \mathbf{y}_{\mathrm{t}}$ seja estacionária, $\mathrm{I}(0)$, para algum vetor a (n x 1) não nulo".

Quando há mais de duas variáveis contidas em $\mathbf{y}_{\mathrm{t}}$, o vetor a não é único. Desse modo, pode existir mais de uma relação de co-integração entre as séries analisadas. Um procedimento que pode ser utilizado para obter uma estimativa consistente do vetor de co-integração a é o que parte da suposição de que um dos coeficientes de a é diferente de zero. Assim, pode-se estimar uma regressão sujeita à condição de normalização, onde o coeficiente associado ao elemento da série temporal $\mathbf{y}_{\mathbf{t}}$, colocado ao lado esquerdo da equação de regressão, é unitário (Hamilton, 1994, p. 587). O uso 
desse procedimento para determinar um único vetor de co-integração foi primeiramente proposto por Granger (1986) e, posteriormente, por Engle e Granger (1987).

$\mathrm{O}$ método de Engle e Granger para detectar co-integração entre séries temporais consiste em estimar uma regressão entre as variáveis não-estacionárias e integradas de mesma ordem - tomadas em níveis. Se os resíduos dessa regressão forem estacionários, isto é, integrados de ordem zero, tem-se evidência de que as séries cointegram.

A principal crítica ao método de Engle e Granger decorre do fato de apenas uma relação de co-integração ser determinada, sendo a mesma sensível à escolha, muitas vezes arbitrária, da variável dependente (Dickey, Jansen \& Thornton ${ }^{38}$, conforme Blumenschein, 1995, e Hamilton, 1994, p. 630). O método de Engle e Granger é sensível a essa escolha porque o teste é aplicado sobre o termo de erro da regressão, que, por sua vez, muda com a variável a ser colocada ao lado esquerdo da equação de regressão.

Harris (1995, p. 62-66), analisando os problemas relacionados com a abordagem de equação simples para determinar relações de co-integração, conclui que essa abordagem só deve ser utilizada quando de fato existe um único vetor de cointegração e todas as variáveis colocadas ao lado direito da equação são fracamente exógenas $^{39}$. Se essas condições forem satisfeitas, a aceitação da hipótese de exogeneidade fraca implica que a relação de longo prazo pode ser estimada a partir de uma única equação. Como não é possível determinar a priori o número de relações de co-integração em um sistema com mais de duas variáveis, a partir da abordagem de equação simples, tornam-se patentes as dificuldades operacionais do método de Engle e Granger em trabalhos aplicados.

Uma forma alternativa de determinar as relações de co-integração foi inicialmente proposta por Johansen (1988) e, posteriormente, por Johansen \& Juselius (1990). O método de Johansen, como ficou conhecido, remove a restrição de se ter que

\footnotetext{
${ }^{38}$ Dickey, D., Jansen, D. W., Thornton, D.L. A primer on cointegration with an application to money and income. Federal Reserve Bank of St. Louis Review, v. 73. n. 2, p. 58-78, 1991.

${ }^{39}$ De modo geral, uma variável é considerada exógena quando o seu processo gerador pode ser ignorado para fins de estimação. A condição para exogeneidade, seus vários conceitos e suas implicações podem ser encontrados em Engle et al (1983). Na página 65 segue condição necessária e suficiente para exogeneidade fraca de uma variável em relação a um determinado vetor de co-integração.
} 
escolher a priori qual deva ser a variável endógena ao sistema, assumindo que todas as variáveis são endógenas simultaneamente. As relações de co-integração para um sistema $n$-dimensional são estimadas de forma sistêmica a partir de um processo vetorial autoregressivo de ordem " $\mathrm{p}$ " reparametrizado, conforme segue abaixo ${ }^{40}$ :

$\Delta \mathbf{Z}_{\mathrm{t}}=\Pi \mathbf{Z}_{\mathrm{t}-1}+\sum_{j=1}^{p-1} \prod_{j} \Delta \mathbf{Z}_{\mathrm{t} \cdot \mathrm{j}}+\psi \mathrm{D}_{\mathrm{t}}+\boldsymbol{\varepsilon}_{\mathrm{t}} \quad \mathrm{t}=1, \ldots, \mathrm{T}$

no qual $\mathbf{Z}_{\mathrm{t}}$ é um vetor $(\mathrm{n} \times 1)$ de variáveis não-estacionárias. Para o propósito da presente pesquisa, considerou-se o caso em que todas as variáveis contidas em $\mathbf{Z}_{\mathrm{t}}$ são integradas de primeira ordem [I(1)]. Deste modo, $\Delta \mathbf{Z}_{\mathrm{t}}$ é u m vetor de variáveis estacionárias (I(0)).

Associado ao vetor de variáveis defasadas integradas de ordem um $\left(\mathbf{Z}_{\mathrm{t}-1}\right)$ está a matriz $\Pi$ de dimensão $(n \times n)$, que é dada pelo produto de duas matrizes, quais sejam, $\alpha$ e $\beta^{\prime}$. A matriz $\alpha$ fornece uma medida da velocidade média de convergência para o equilíbrio de longo prazo (Hansen \& Juselius, 1995).

Para o propósito da presente pesquisa, se for possível interpretar um dos vetores de co-integração como uma equação para o saldo da balança comercial agrícola total, então o coeficiente $\alpha$ associado a essa variável fornecerá a velocidade média na qual o saldo da balança comercial agrícola total se ajusta em resposta a um choque na forma de impulso na relação de equilíbrio ${ }^{41}$.

A matriz $\beta$ é constituída pelos coeficientes de longo prazo, de modo que $\left(\beta^{\prime} \mathbf{Z}_{t-1}\right)$ fornece as relações de co-integração do modelo multivariado (isto é, as relações de longo prazo), que asseguram que $\mathbf{Z}_{\mathrm{t}}$ converge para sua solução estática de longo prazo (Harris, 1995, p. 79), caso as relações de co-integração existam. Ademais, tem-se assegurado que, para cada relação de co-integração encontrada, as combinações $\beta^{\prime} \mathbf{Z}_{t-1}$ são de fato estacionárias, mesmo quando o vetor $\mathbf{Z}_{\mathrm{t}}$ não exibe estacionariedade (Johansen e Juselius, 1990, p.170, e Haug, 1996, p. 97). Em resumo: a matriz П reúne todos os coeficientes associados às variáveis incluídas no espaço de co-integração.

\footnotetext{
${ }^{40}$ Consultar Johansen (1988 e 1991) para mais detalhes acerca do modelo utilizado na presente pesquisa.

${ }^{41}$ Interpretação baseada em Williams \& Beley (1993, p. 37).
} 
Os coeficientes da parte dinâmica do modelo são fornecidos pelas matrizes $\Gamma_{j}$, de modo que $\sum_{j=1}^{p-1}, \Delta \mathbf{Z}_{t-j}$ fornece as relações de curto prazo do modelo multivariado. O número de defasagens "p" utilizado deve ser aquele que torne o termo de erro $\left(\varepsilon_{t}\right)$ não correlacionado temporalmente. Mais uma vez utilizou-se o critério de Schwarz para selecionar a ordem de defasagens para estimar os vetores auto-regressivos do sistema. Haug (1996, p. 95-96), citando Reimers ${ }^{42}$, sugere que o critério de Schwarz para selecionar a ordem de defasagem em sistemas VAR co-integrados é superior ao critério de Akaike. Além do critério de Schwarz, fez-se também uso de testes de diagnósticos do resíduo $\left(\varepsilon_{\mathrm{t}}\right)$.

Por fim, o vetor $\psi$ no VAR não-restrito (14) contém os coeficientes que captam os impactos de choques de curto prazo no sistema, tais como políticas de intervenção e impacto de choques externos, geralmente operacionalizados na forma de variáveis binárias contidas em $\mathbf{D}_{\mathfrak{t}}($ Harris, 1995, p. 81). De acordo com Hansen \& Juselius (1995, p.1 e 12), o vetor $\mathbf{D}_{\mathbf{t}}$ também pode conter variáveis exógenas fracas nãoestacionárias que podem ser excluídas do espaço de co-integração, se algumas condições forem satisfeitas (como será visto adiante).

Johansen \& Juselius (1990) propuseram duas estatísticas para determinar o número de relações de co-integração do sistema multivariado (14). A primeira é a estatistica traço, simbolicamente representada por $\lambda_{\text {traço, }}$ e a segunda é a estatística de autovalor máximo ou $\lambda_{\max }$.

A estatística $\lambda_{\text {traco }}$ é calculada do seguinte modo:

$\lambda_{\text {traco }}(\mathrm{r})=-\mathrm{T} \sum_{i=r+1}^{n} \ln \left(1-\hat{\lambda}_{i}\right) \quad$ com $\mathrm{r}=0,1,2, \ldots, \mathrm{n}-1$

em que: $\mathrm{T}$ é o número de observações disponíveis; $\hat{\lambda}_{i}$ é o valor da i-ésima raiz característica da estimativa da matriz $\Pi$; r é o posto da matriz $\Pi$ (número de relações de

${ }^{42}$ Reimers, H., 1993, Lags order determination in cointegrated VAR systems with application to small German macromodels, Paper presented at the 1993 Econometric Society European Meeting, Uppsala. 
co-integração); e, n é o número de variáveis do sistema ${ }^{43}$. A hipótese nula testada pela estatística traço é a de que o número de relações de co-integração é menor ou igual a $r$, enquanto a hipótese alternativa é genérica. Por exemplo, quando se testa a hipótese nula de que $r=0$, a hipótese alternativa é a de que $r>0$.

Os valores calculados da estatística $\lambda_{\max }$ são obtidos a partir da seguinte fórmula:

$\lambda_{\max }(\mathrm{r}, \mathrm{r}+1)=-\mathrm{T} \ln \left(1-\hat{\lambda}_{r+1}\right) \quad$ com $\mathrm{r}=0,1,2, \ldots, \mathrm{n}-1$

com $\mathrm{T}, \hat{\lambda}$ e r definidos como antes.

A hipótese nula testada pela estatística $\lambda_{\max }$ é o número de relações de co-integração ser igual a r, enquanto a hipótese alternativa é o número de relações de cointegração ser igual a $(r+1)$.

A determinação do número de relações de co-integração (isto é, o posto, r, da matriz $\Pi$ ), a partir do modelo (14), pressupõe que a matriz $\Pi$ tem posto incompleto (Johansen e Juselius, 1990, p. 170) ${ }^{44}$. Ou seja, admite-se que a matriz $\Pi$ terá posto menor ou igual ao número de variáveis envolvidas no sistema menos um [isto é, $r$ $\leq(n-1)]$. Portanto, somente se o posto da matriz $\Pi$ for menor ou igual a $n-1$ é que $\Pi$ será igual $\alpha \beta^{\prime}$ (Haug, 1996, p.97).

De acordo com Johansen \& Juselius (1990, p. 170) existe ainda a possibilidade de ocorrência de dois casos extremos para o posto da matriz $\Pi$, quais sejam:

a) A matriz $\Pi$ tem posto completo, isto é, o posto de $\Pi$ é igual ao número de variáveis incluídas no sistema. Nesse caso, o modelo apropriado para estimar as

\footnotetext{
${ }^{43} \mathrm{O}$ número de vetores de co-integração é igual ao posto da matriz $\Pi$, que por sua vez é igual ao número de raizes características diferentes de zero (Enders, 1996, 175).

44 Se a matriz $\Pi$ tem posto incompleto, então "as últimas $(n-r)$ combinações obtidas, a partir do procedimento de Johansen, indicam as combinações não-estacionárias, e teoricamente nãocorrelacionadas com as combinações estacionárias" do modelo (14) (Harris, 1995, p. 87).
} 
relações entre as variáveis do sistema seria um VAR em nível, dado que todas as variáveis contidas no vetor $\mathbf{Z}_{\mathrm{t}}$ seriam de fato estacionárias.

b) A matriz ПI apresenta posto igual a zero. Isto implica que a matriz II é nula e o modelo (14) transforma-se em um VAR em primeira diferença, não existindo, portanto, relações de co-integração. Nessa situação, qualquer combinação linear entre as variáveis (em nível) incluídas no sistema será não-estacionária.

$\mathrm{Na}$ presente pesquisa, $\mathrm{o}$ posto da matriz $I I$ foi determinado conjuntamente com o número de componentes determinísticos a serem incluídos no modelo (14), conforme sugerido por Johansen (1992). Para tanto, fez-se uso do critério de Pantula. O critério de Pantula consiste em testar as hipóteses nulas de não-cointegração para um conjunto de modelos. Operacionalmente, estimam-se os prováveis modelos e o número de relações de co-integração $(r=0, r=1, r=2, \ldots, r=n-1$; sendo n o número de variáveis incluídas no espaço de co-integração) vai sendo testado modelo a modelo, indo do mais restrito (modelo sem nenhum componente determinístico) até o menos restrito (modelo contendo termo constante e tendência temporal). O teste tem fim assim que a hipótese nula de não-co-integraçã o não puder ser rejeitada. Ou seja, testa-se, primeiramente, a hipótese de que $\mathrm{r}=0$ em cada modelo. Se a hipótese nula for rejeitada, segue-se testando que $r=1$, e assim sucessivamente. Assim que a hipótese nula não puder ser rejeitada o teste é finalizado, escolhendo-se o modelo para o qual a hipótese nula foi aceita ${ }^{45}$.

Após ter selecionado o modelo e determinado o número de relações de co-integração, o próximo passo consiste em estimar os vetores de co-integração e testar a hipótese nula de exogeneidade fraca para as variáveis incluídas nas relações de cointegração. De acordo com Johansen (1992, p. 393), a aceitação da hipótese de "exogeneidade fraca para um conjunto de variáveis com relação aos parâmetros de longo prazo $(\alpha, \beta)$ implica que o estimador de máxima verossimilhança no sistema completo é

\footnotetext{
${ }^{45}$ Para maiores detalhes ver Harris (1995, p. 97).
} 
idêntico ao estimador (parcial) de máxima verossimilhança obtido a partir do sistema parcial" $^{46}$

Portanto, na presença de exogeneidade fraca para um conjunto de variáveis, as relações de longo prazo podem ser estimadas (sem perda de efeciência) a partir de um subsistema VAR, em que apenas as equações para as variáveis endógenas são modeladas explicitamente. Existindo um único vetor de co-integração e apenas uma única variável endógena ao sistema, a análise pode ser reduzida a estimação de uma única equação (ver Johansen, 1992).

No presente trabalho, o teste de exogeneidade fraca foi realizado pressupondo-se que um dos vetores possa ser interpretado como uma equação para o saldo da balança comercial agrícola total.

As relações de co-integração estimadas pelo método de Johansen a partir do VAR não-restrito (modelo 14) pressupõem que todas as variáveis incluídas no espaço de co-integração são endógenas, não permitindo, portanto, uma interpretação econômica precisa dos parâmetros de longo prazo estimados. Portanto, o teste de exogeneidade fraca se faz necessário para determinar se é possível interpretar um dos vetores de cointegração como uma equação para o saldo da balança comercial agrícola total, que constitui um dos objetivos específicos da presente pesquisa.

O teste de exogeneidade fraca é feito impondo restrições zero aos coeficientes da matriz $\alpha$, que, conforme visto, fornece uma medida da velocidade média de convergência para o equilíbrio de longo prazo (Hansen \& Juselius, 1995, p. 3). A hipótese nula testada é a de que o coeficiente $\alpha_{\mathrm{ij}}$ não difere significativamente de zero, com i identificando a variável (supostamente exógena) e j o vetor de co-integração em análise.

Portanto, a condição para que uma variável seja considerada exógena fraca, com relação a um vetor de co-integração particular, é que o coeficiente $\alpha_{\mathrm{ij}}$, a ela associado, não seja estatisticamente diferente de zero (Harris, 1995, p.98-104; e Hansen \& Juselius, 1995, p.12). Ainda de acordo com os mesmos autores, se esse for o caso,

\footnotetext{
${ }^{46} \mathrm{Na}$ presente pesquisa o sistema completo é o modelo (14).
} 
então os parâmetros da relação de longo prazo contidos em $\beta$ não entram na equação determinando $\Delta \mathbf{Z}_{\mathrm{it}}$, com i indicando a variável exógena. Isto é, a equação de curto prazo para a variável exógena fraca não deve conter informações acerca das relações de longo prazo. Por essa razão, o sistema é reestimado impondo restrições zero sobre os coeficientes $\alpha_{\mathrm{ij}}$ das variáveis exógenas fracas. Obtém-se, assim, um modelo VAR restrito $^{47}$, a partir do qual são feitas as análises de co-integração.

Se a variável exógena fraca for insignificante nas relações de cointegração, então o modelo VAR restrito pode ser reformulado com o objetivo de excluir a referida variável das relações de longo prazo (Hansen \& Juselius, 1995, p.12). Desse modo, a variável exógena fraca fica restrita apenas à parte dinâmica do modelo. Contudo, esse é um critério puramente estatístico, não existindo nenhuma razão teórica que justifique a exclusão de tal variável do espaço de co-integração. Por isso, na presente pesquisa optou-se por continuar com a especificação dada pelo modelo VAR restrito (aquele estimado impondo restrições zero aos coeficientes de ajustamento das variáveis exógenas fracas), mesmo que seja constatada a presença de exogeneidade fraca e insignificância de algumas variáveis nas relações de longo prazo. Ademais, deve-se atentar para o fato de que o tamanho da amostra utilizada é particularmente pequeno (35 observações), o que, provavelmente, pode interferir no grau de significância dos coeficientes estimados.

Os testes de restrições sobre $\alpha$ e $\beta$ foram realizados fazendo-se uso da estatística razão de verossimilhança (LR). Estabeleceu-se o limite crítico, em todos os testes realizados, de 5\% para rejeição das hipóteses nulas. A distribuição assintótica dessa estatística é qui-quadrado (para maiores detalhes ver Johansen \& Juselius, 1990; e Johansen, 1991).

Por fim, a escolha do método de Johansen para estimar as relações de cointegração não foi arbitrária. A escolha desse método teve por base os resultados da

\footnotetext{
${ }^{47}$ De acordo com Harris (1995, p. 98), pode-se ter ainda a seguinte interpretação: "se há (r $\leq$ (n-1)) vetores co-integrados contidos em $\beta$, então isto implica que as últimas (n-r) colunas de $\alpha$ são zero". O mesmo autor conclui: testar quantos vetores co-integrados existem em $\beta$, equivale a testar quantas colunas de $\alpha$ são zeros.
} 
pesquisa de Gonzalo (1994). O principal objetivo da pesquisa de Gonzalo foi selecionar o melhor método de estimação de vetores de co-integração para fins de pesquisas empíricas.

Gonzalo (1994) examinou a distribuição assintótica dos estimadores de cinco métodos alternativos de estimação de vetores de co-integração, quais sejam: mínimos quadrados ordinários; mínimos quadrados não-lineares; máxima verossimilhança em um modelo de correção de erro (método de Johansen); componentes principais; e correlação canônica. Gonzalo concluiu que as estimativas produzidas pelo método de Johansen têm melhores propriedades que as produzidas pelos demais métodos analisados, com os resultados obtidos sendo também válidos quando a estimação é feita a partir de amostras finitas.

Ademais, Gonzalo (1994, p. 224) atesta ainda que, dos cinco métodos analisados, o de Johansen foi o único que satisfez a três requisitos desejáveis na estimação de vetores de co-integração, quais sejam: i) incorporação de informações $a$ priori acerca da existência de raiz unitária; ii) estimação de sistema pleno; e, iii) obtenção dos efeitos dinâmicos do sistema.

\subsubsection{Modelo de correção de erros}

Com base no Teorema de Representação de Granger é possível mostrar que se existe relação de co-integração entre variáveis de séries temporais, então um modelo de correção de erros pode ser especificado (ver Granger \& Engle,1987, p. 25559). O modelo de correção de erros permite que se obtenham os impactos de curto prazo das variáveis explanatórias (as variáveis exógenas fracas) sobre a variável dependente (saldo da balança comercial agrícola total), sem que haja perda das informações de longo prazo.

$\mathrm{Na}$ especificação do modelo de correção de erros, a variável dependente (em sua primeira diferença) passa a ser função do termo de erro da equação de cointegração do modelo VAR restrito, defasado de um período, das primeiras diferenças

defasadas da variável endógena e das primeiras diferenças correntes e defasadas das 
variáveis explanatórias ${ }^{48}$. O número de defasagens a ser incluído no modelo de correção de erros é igual ao número de defasagens utilizado para estimar o modelo VAR menos um.

\subsection{Definição das variáveis e fontes de dados}

Como já foi explicitado no item 4.2 do capítulo 4 , as variáveis consideradas na pesquisa são: saldo da balança comercial dos setores agrícola e agroindustrial (SAT); taxa de câmbio (e-IPA); termos de troca (TT); nível de atividade doméstica (RB); nível de atividade externa (RW); e, uma variável binária (D). A seguir, explica-se como essas variáveis foram calculadas e operacionalizadas.

\section{a) Saldo da balança comercial agrícola total}

O saldo da balança comercial agrícola total (SAT) inclui todos os produtos agrícolas básicos, animais vivos e produtos florestais, bem como os produtos industriais derivados desses produtos básicos. Utilizaram-se os dados divulgados pela FAO, considerando-se 397 produtos $^{49}$. As transações com fertilizantes e defensivos agrícolas não foram consideradas porque as séries para essa categoria de produto não cobrem o ano de 1995. Também excluíram-se as séries para os produtos nos quais as transações comerciais foram inferiores a 4 anos, que, por pressuposição, decorreram de frustações de safra ou outras questões conjunturais na economia brasileira e/ou na economia do resto do mundo. Os valores do saldo da balança comercial agrícola total estão expressos em dólares de 1995, sendo utilizado o Índice de Preços no Atacado dos Estados Unidos como deflator.

\footnotetext{
${ }^{48}$ A especificação do modelo de correção de erros comentada pessupõe que as variáveis explanatórias sejam exógenas em relação ao modelo de curto prazo.

${ }^{49}$ Desses 397 produtos, 357 são produtos agrícolas e agroindustriais, 12 são animais vivos e 28 são matéria-prima florestal e produtos industriais baseados na madeira.
} 


\section{b) Índices de competitividade de preço}

b.1) Taxa de câmbio (e-IPA)

Como já foi explicado no item 2.1 do capítulo 2, existe diferença entre uma desvalorização na taxa de câmbio real e uma desvalorização na taxa de câmbio efetiva real. A primeira refere-se a uma queda no valor da moeda doméstica em termos da moeda estrangeira de referência, usualmente o dólar americano ou a moeda do principal parceiro comercial. A segunda ocorre quando se usa uma cesta de moedas constituída geralmente pelas moedas dos principais parceiros comerciais do país para proceder às desvalorizações. Desse modo, a taxa de câmbio efetiva real é a que interessa para o desempenho do saldo da balança comercial, uma vez que o mesmo é o resultado das transações comerciais líquidas de mercadorias do país com o resto do mundo.

Por esta razão, no presente trabalho a taxa de câmbio foi operacionalizada utilizando o conceito de taxa de câmbio efetiva real. Como deflatores da taxa de câmbio efetiva utilizaram-se o Índice de Preços no Atacado (IPA) dos principais parceiros comerciais do Brasil e o IPA doméstico. Os IPAs externos foram ponderados pela participação relativa de cada país nas transações comerciais totais (exportações e importações) com o Brasil. As ponderações foram alteradas a cada cinco anos. Os países considerados na cesta de moedas foram: Estados Unidos, Grã-Bretanha, Bélgica, Dinamarca, França, Alemanha, Itália, Holanda, Noruega, Suécia, Suíça, Canadá, Japão, Espanha, Argentina, Chile, México, Paraguai e Venezuela. O ano base da série é 1985, escolhido porque naquele ano "a taxa real de câmbio estava relativamente alinhada com a competitividade externa da economia e não pode ser caracterizada como demasiadamente elevada" (ver Zini Jr., 1993, p. 25). 


\section{b.2) Termos de troca (TT)}

Como uma proxy dos termos de troca, utilizou-se a razão entre os índices de valor unitário médio das exportações e importações. O índice construído foi do tipo Laspeyres $^{50}$, tendo como base o ano de 1961. Uma elevação no índice acusa uma melhora nos termos de troca.

\section{c) Indicadores do nível de atividade interna e externa}

c.1) Nível de atividade doméstica (RB)

O nível de atividade doméstica é medido pelo Produto Interno Bruto (PIB) do Brasil, a preços de 1995, utilizando o deflator implícito do PIB.

c.2) Nível de atividade externa (RW)

Utilizou-se o valor das importações do resto do mundo de produtos agrícolas e agroindustriais como uma proxy do nível de renda externa disponível para despesas com produtos agrícolas básicos e processados. Os valores estão expressos em dólares de 1995, tendo-se utilizado como deflator o Índice de Preços no Atacado dos Estados Unidos.

\section{d) Variável para captar choque exógeno}

É incluída uma variável binária para captar o efeito da geada ocorrida no Brasil em 1975 sobre os preços do café no mercado internacional nos anos de 1976 e 1977 e, consequentemente, sobre o saldo da balança comercial agrícola total. A variável binária tem valor 1 para os anos de 1976 e 1977 e valor zero para os demais anos. Assim,

${ }^{50}$ Detalhes acerca do cálculo do índice de Laspeyres podem ser encontrados em Hoffmann $(1991,314)$. 
admite-se que a geada em questão teve efeito temporário sobre o saldo da balança comercial de produtos agrícolas e agroindustriais do Brasil.

Observe que a geada de 1975 é operacionalizada na forma de um choque temporário, com efeito apenas sobre as relações de curto prazo ${ }^{51}$.

Os valores das variáveis estão na Tabela 1 (na página 74) e se referem ao período de 1961 a 1995, totalizando, para cada variável, 35 observações. Verifica-se que nenhuma das variáveis apresenta valor negativo. Todas as séries, exceto a que se refere à variável binária, são utilizadas na forma logarítmica ${ }^{52}$.

\subsection{0 modelo econométrico a ser estimado}

Com as variáveis acima definidas, o modelo a ser estimado é o VAR nãorestrito [ver modelo (14)], no qual:

$\mathbf{Z}_{\mathrm{t}}=\left[\mathrm{SAT}_{\mathrm{t}}, \mathrm{e}-\mathrm{IPA}_{\mathrm{t}}, \mathrm{TT}_{\mathrm{t}}, \mathrm{RB}_{\mathrm{t}}, \mathrm{RW}_{\mathrm{t}}\right]^{\prime}$;

$\mathbf{D}_{\mathbf{t}}=1$ para os anos de 1976 e 1977, e zero para os demais anos da série;

$\Pi=\alpha \beta^{\prime} ; \mathrm{e}$,

$\alpha, \beta, \Gamma$ e $\psi$ são matrizes (ou vetores) de parâmetros a serem estimados.

A primeira etapa do processo consiste em estimar o modelo (14) usando os dados da Tabela 1 e considerando que todas as variáveis (SAT, e-IPA, TT, RB e RW) sejam endógenas simultaneamente. Este é o VAR não-restrito. O vetor de cointegração estimado a partir do modelo (14) é apresentado no Quadro 5 (na página 79).

Determinado o número de vetores de co-integração existente, o passo seguinte consiste em prosseguir a estimação do modelo impondo restrições zero a $\alpha$ para as variáveis exógenas fracas em relação aos vetores de co-integração em análise. Procedendo dessa forma, a análise é restringida a um subsistema VAR, em que apenas as equações para as variáveis endógenas são modeladas explicitamente. Este é o VAR

\footnotetext{
${ }^{51}$ A inclusão da variável binária também se fez necessária para tornar as estimativas mais estáveis.

${ }^{52}$ Como medida da renda doméstica, RB, e da taxa de câmbio foram utilizadas, alternativamente, o Produto Interno Bruto do Setor Agrícola e a taxa de câmbio efetiva real, e-TNT, respectivamente. Não obstante, os melhores ajustamentos foram obtidos quando se fez uso dos dados apresentados na Tabela 1 .
} 
restrito, que também será denominado de modelo condicional, a partir do qual são realizadas as interpretações econômicas das relações de longo prazo entre as variáveis em estudo. O vetor de co-integração estimado a partir deste procedimento é reportado no Quadro 6 (na página 80).

A rigor, o modelo condicional é aquele em que as variáveis exógenas fracas também aparecem de forma corrente na parte dinâmica do modelo (curto prazo). Esse procedimento conduziria à estimação de um grande número de parâmetros, implicando em perda de graus de liberdade. Como a amostra utilizada é constituída por 35 observações, a perda de graus de liberdade poderia comprometer a qualidade das estimações. Desse modo, optou-se por condicionar as variáveis exógenas fracas apenas no modelo de correção de erros (que foi estimado separadamente), a partir do qual são determinadas as relações de curto prazo. As equações de curto prazo estimadas por esse procedimento encontram-se nas Tabelas 5 e 6 (páginas 86 e 88, respectivamente). 
Tabela 1. Saldo comercial agrícola total (SAT); taxa de câmbio efetiva real (e-IPA); termos de troca (TT); renda doméstica (RB); renda externa (RW); e, variável binária (D).

\begin{tabular}{ccccccc}
\hline \hline Anos & SAT & e-IPA & TT & $R^{(2)}$ & RW & D \\
\hline \hline 1961 & 3865,23 & 76,74 & 100 & 127807,20 & 163448,71 & 0 \\
1962 & 3071,86 & 86,41 & 93,24 & 136191,97 & 169376,97 & 0 \\
1963 & 3771,82 & 75,00 & 92,10 & 137007,45 & 185111,23 & 0 \\
1964 & 3598,64 & 91,29 & 104,63 & 141693,00 & 203415,51 & 0 \\
1965 & 4165,35 & 105,23 & 106,26 & 145093,98 & 205846,49 & 0 \\
1966 & 4382,08 & 89,37 & 98,93 & 154836,33 & 212113,00 & 0 \\
1967 & 3698,34 & 80,92 & 93,24 & 161301,13 & 210313,86 & 0 \\
1968 & 4281,34 & 83,89 & 98,30 & 177106,00 & 211567,87 & 0 \\
1969 & 5284,29 & 87,72 & 106,65 & 193963,10 & 221002,48 & 0 \\
1970 & 5756,06 & 87,11 & 127,12 & 214128,64 & 238796,88 & 0 \\
1971 & 5369,17 & 88,41 & 105,01 & 238919,69 & 246856,94 & 0 \\
1972 & 7475,63 & 91,20 & 118,62 & 267239,71 & 276446,79 & 0 \\
1973 & 9627,91 & 95,91 & 108,27 & 304500,53 & 349764,25 & 0 \\
1974 & 8416,13 & 94,77 & 93,34 & 329744,01 & 373939,65 & 0 \\
1975 & 8516,00 & 99,22 & 98,11 & 346435,73 & 353494,03 & 0 \\
1976 & 10053,77 & 95,73 & 157,67 & 382043,71 & 365261,95 & 1 \\
1977 & 12740,94 & 95,12 & 287,03 & 400618,75 & 394727,06 & 1 \\
1978 & 9229,65 & 100,44 & 196,35 & 420559,34 & 411554,18 & 0 \\
1979 & 7990,96 & 111,24 & 181,32 & 449047,00 & 440190,24 & 0 \\
1980 & 10301,82 & 117,77 & 142,82 & 490813,40 & 438381,06 & 0 \\
1981 & 10294,85 & 100,00 & 97,39 & 469761,29 & 393166,15 & 0 \\
1982 & 8265,68 & 93,29 & 101,44 & 473464,02 & 359156,61 & 0 \\
1983 & 10076,14 & 110,63 & 126,55 & 459738,69 & 346856,70 & 0 \\
1984 & 11748,92 & 101,83 & 147,57 & 484640,63 & 357625,59 & 0 \\
1985 & 10516,39 & 100,00 & 138,43 & 522413,69 & 348949,10 & 0 \\
1986 & 7331,90 & 101,66 & 232,75 & 561476,70 & 392224,33 & 0 \\
1987 & 9632,77 & 103,48 & 157,16 & 581181,36 & 436374,14 & 0 \\
1988 & 11975,66 & 92,16 & 138,31 & 580628,88 & 475474,91 & 0 \\
1989 & 9463,82 & 72,65 & 95,62 & 599264,37 & 479458,40 & 0 \\
1990 & 8272,53 & 68,21 & 89,93 & 574584,47 & 496394,16 & 0 \\
1991 & 6969,99 & 80,84 & 107,77 & 576037,43 & 491185,93 & 0 \\
1992 & 8740,54 & 83,19 & 83,03 & 571275,45 & 521788,48 & 0 \\
1993 & 8482,05 & 75,78 & 90,01 & 595514,87 & 477481,66 & 0 \\
1994 & 10570,67 & 63,41 & 153,64 & 631062,77 & 535867,68 & 0 \\
1995 & 9657,25 & 54,70 & 128,20 & 658100,00 & 591072,87 & 0 \\
\hline \hline Nof & & & &
\end{tabular}

Nota: ${ }^{(1)}$ Valores expressos em bilhões de dólares de 1995, tendo como fonte dos dados básicos FAO - Home page: apps.fao.org. ${ }^{(2)}$ Dados formecidos pessoalmente por Antônio Álvaro Zini Júnior ${ }^{(3)}$ Valores expressos em bilhões de reais de 1995, e tem como fonte dos dados básicos a FGV - Conjuntura Econômica, Ano 51, nº 04, abril de 1997 . 


\section{RESULTADOS E DISCUSSÃO}

Nesta seção são apresentados e discutidos os resultados obtidos nos testes de raiz unitária (item 6.1), na estimação do vetor de co-integração (item 6.2) e na equação de correção de erros (item 6.3). Com base nos testes de exogeneidade fraca, o vetor de co-integração pode ser interpretado como uma equação reduzida para o saldo da balança comercial agrícola total.

\subsection{Testes de raiz unitária}

Os resultados dos testes de raiz unitária reportados na Tabela 2 sugerem que as séries das variáveis (saldo da balança comercial agrícola total, termos de troca, taxa de câmbio efetiva real, renda doméstica e renda externa) não apresentam duas raízes unitárias, o que é um indicativo de que as referidas séries sejam estacionárias em primeira diferença.

Tabela 2. Testes Dickey-Fuller Aumentado de raiz unitária: variável dependente em segunda

\begin{tabular}{|c|c|c|c|c|c|c|}
\hline \multirow[t]{2}{*}{ Variáveis } & \multirow{2}{*}{$\begin{array}{c}^{\circ} \mathrm{de}^{(1)} \\
\text { defasagens }\end{array}$} & \multirow{2}{*}{$\begin{array}{c}\text { № de } \\
\text { observações }\end{array}$} & \multicolumn{4}{|c|}{ Testes estatisticos } \\
\hline & & & $\tau_{u_{\mu}}$ & $\phi_{1}$ & $t$ & $\tau$ \\
\hline In SAT & 1 & 32 & $-6,97^{\mathrm{a}}$ & $24,29^{a}$ & $-6,97^{\mathrm{a}}$ & $-6,65^{a}$ \\
\hline $\ln T T$ & 0 & 33 & $-5,68^{\mathrm{a}}$ & $16,13^{\mathrm{a}}$ & $-5,68^{\mathrm{a}}$ & $-5,76^{\mathrm{a}}$ \\
\hline In e-IPA & 1 & 32 & $-5,47^{a}$ & $14,95^{\mathrm{a}}$ & $-5,47^{a}$ & $-5,52^{\mathrm{a}}$ \\
\hline In $R B$ & 0 & 33 & $-3,18^{b}$ & $5,07^{\mathrm{ns}}$ & $-3,18^{a}$ & $-2,08^{b}$ \\
\hline In RW & 0 & 33 & $-3,97^{a}$ & $7,91^{a}$ & $-3,97^{a}$ & $-3,30^{a}$ \\
\hline
\end{tabular}

Fonte: Dados da pesquisa

OBS.: os sobrescritos "a" e "b" indicam significância aos níveis de $1 \%$ e $5 \%$, respectivamente.

(1) $\mathrm{O}(\mathrm{p}-1)$ das equações do Quadro 4. 
Por outro lado, os resultados apresentados na Tabela 3 indicam que não se pode rejeitar a hipótese nula de uma raiz unitária para todas as séries em análise (nenhum dos testes dessa tabela foi estatisticamente significativo ao nível de $5 \%$ ). Desse modo, aceita-se a hipótese de que as séries em nível são todas I(1), isto é, integradas de primeira ordem. Ademais, os testes para as hipóteses nulas conjuntas sugerem que o processo gerador das séries (saldo da balança comercial agrícola total, termos de troca, taxa de câmbio efetiva real, renda doméstica e renda externa) apresenta uma raiz unitária e nenhum componente de tendência temporal.

Tabela 3. Testes Dickey-Fuller Aumentado de raiz unitária: variável dependente em primeira diferença $\left(\Delta \ln y_{t}\right)$.

\begin{tabular}{lcccccccc}
\hline Variáveis & $\begin{array}{c}\mathrm{N}^{\circ} \text { de } \\
\text { defasagens }\end{array}$ & $\begin{array}{c}\mathrm{N}^{\circ} \text { de } \\
\text { observações }\end{array}$ & \multicolumn{1}{c}{$\tau_{\tau}$} & $\phi_{3}$ & $\tau_{\mu}$ & $\phi_{1}$ & $\mathrm{t}$ & $\tau$ \\
\hline In SAT & 2 & 32 & $-1,03$ & 1,61 & $-1,83$ & 2,95 & - & 1,45 \\
In TT & 0 & 34 & $-2,79$ & 3,91 & $-2,79$ & 3,90 & - & 0,01 \\
In e-IPA & 2 & 32 & $-0,55$ & 4,10 & $-0,43$ & 0,20 & - & $-0,50$ \\
In RB & 1 & 33 & $-0,90$ & 1,25 & $-1,52$ & 3,90 & - & 2,19 \\
In RW & 1 & 33 & $-2,45$ & 3,07 & $-1,18$ & 2,69 & - & 1,94 \\
\hline
\end{tabular}

Fonte: Dados da pesquisa

Obs.: Nenhum dos testes foi estatisticamente significativo ao nivel de $5 \%$.

\subsection{Teste de co-integração}

As relações de co-integração foram estimadas pelo método proposto por Johansen. O sistema estimado envolveu cinco variáveis I(1), tomadas em seus logaritmos, quais sejam: i) saldo da balança comercial agrícola total (SAT); ii) taxa de câmbio efetiva real (e-IPA); iii) termos de troca (TT); iv) renda interna (RB); v) renda externa (RW); e, uma variável binária de intervenção operacionalizada na forma de impulso, para captar o efeito da geada de 1975 sobre os preços do café no mercado internacional nos anos de 1976 e 1977 e, consequentemente, sobre o saldo da balança comercial agrícola total. 
O critério de Schwarz indicou que deve ser estimado um sistema VAR de ordem um. Mas, levando-se em conta que mais uma defasagem foi necessária para tornar os resíduos não-correlacionados serialmente, optou-se por estimar um sistema VAR de ordem dois, a partir do qual realizaram-se as análises de co-integração.

O critério de Pantula, para selecionar o posto da matriz $\Pi$ e o número de componentes determinísticos do modelo, indicou a presença de uma constante no espaço de co-integração e apenas uma relação estável de longo-prazo (um vetor de cointegração) $)^{53}$. Para tanto, os valores críticos das tabelas propostas por Osterwald-Lenum (1992) foram utilizados como indicativos ${ }^{54}$ dos verdadeiros valores assintóticos das estatísticas $\lambda_{\max }$ e $\lambda_{\text {trąo }}$.

Na Tabela 4 apresentam-se os testes para posto incompleto do modelo selecionado pelo critério de Pantula. Com base na estatística $\lambda_{\text {trąo }}$ foi possível rejeitar a hipótese nula, ao nível de $5 \%$ de significância, de que o número de relações de cointegração é igual a zero (isto é, $r=0$ ). Assim sendo, aceita-se a hipótese alternativa de que existe um vetor de co-integração entre as variáveis: saldo da balança comercial agrícola total (SAT); taxa de câmbio efetiva real (e-IPA); termos de troca (TT); renda interna (RB); e, renda externa (RW). A estatística $\lambda_{\max }$ somente ao nível de $10 \%$ de significância rejeita a hipótese nula de que o número de relações de co-integração é igual a zero.

\footnotetext{
${ }^{53} \mathrm{Na}$ aplicação do critério de Pantula, consideraram-se como prováveis modelos um sistema VAR com um termo constante restrito ao espaço de co-integração e, alternativamente, um VAR com uma constante na parte dinâmica do modelo. A seleção dos prováveis modelos teve por base os resultados dos testes de raiz unitária, sugerindo que o processo gerador de cada séries em análise não apresenta um termo de tendência temporal. Ademais, os modelos extremos, quais sejam, modelo sem nenhum componente determinístico e modelo contendo tendência quadrática não foram considerados por serem, na prática, de rara ocorrência (ver Hansen \& Juselius, 1995, p. 5-6; e Harris, 1995, p.96).

${ }^{54}$ Uma vez que os valores críticos das tabelas de Osterwald-Lenum são recomendados apenas quando as variáveis binárias são do tipo sazonais centradas, por não interferirem na distribuição assintótica das estatísticas posto (Hansen \& Juselius, 1995, p. 8).
} 
Tabela 4. Testes para posto incompleto de co-integração do modelo selecionado, usando dados para o período 1961 a 1995.

\begin{tabular}{ccccc}
\hline $\begin{array}{c}\text { Hipótese nula } \\
\text { testada }\end{array}$ & $\begin{array}{c}\text { Relações não- } \\
\text { estacionárias }\end{array}$ & Raizes calculadas & \multicolumn{2}{c}{ Estatísticas calculadas } \\
\hline \hline (Ho: $\mathrm{r})$ & $(\mathrm{n}-\mathrm{r})$ & $\lambda_{\mathrm{i}}$ & $\lambda_{\text {trąo }}$ & $\lambda_{\max }$ \\
0 & 5 & 0,6207 & $78,44^{\mathrm{b}}$ & $31,99^{\mathrm{c}}$ \\
1 & 4 & 0,5158 & 46,45 & 23,93 \\
2 & 3 & 0,3165 & 22,52 & 12,56 \\
3 & 2 & 0,2123 & 9,96 & 7,88 \\
4 & 1 & 0,0612 & 2,08 & 2,08 \\
\hline \hline
\end{tabular}

Fonte: Dados da pesquisa

OBS: Os sobrescritos "b" e "c" indicam rejeição da hipótese nula aos níveis de $5 \%$ e $10 \%$, respectivamente.

No Quadro 5, apresentam-se o vetor de co-integração, normalizado para o logaritmo neperiano da variável saldo da balança comercial agrícola total, $\ln (\mathrm{SAT})$; os coeficientes de ajustamento $\left(\alpha_{i 1}\right)$, que mostram o erro da relação de equilíbrio de longo prazo; e os respectivos teste $t$ de student, que sinalizam as prováveis variáveis exógenas em relações ao modelo de longo prazo. Os valores da estatística t sugerem que a relação de co-integração estimada é estatisticamente significante apenas para a equação do saldo da balança comercial agrícola total.

O coeficiente de ajustamento associado à variável saldo da balança comercial agrícola total apresentou um valor para a estatística t igual a $-4,780$, que é consideralvemente maior que aqueles calculados para as demais variáveis (ver Quadro 5). Segundo Hansen \& Juselius (1995), nesse estágio o valor da estatística $t$ deve ser interpretado com bastante cuidado, servindo apenas como indicativo de que o vetor de co-integração estimado pode ser interpretado do ponto de vista econômico. 
Quadro 5. Vetor de co-integração, coeficientes de ajustamento e estatística t de student.

\begin{tabular}{|c|c|c|c|c|c|}
\hline \multicolumn{6}{|c|}{ Vetor de co-integração, normalizado para a variável saldo da balança comercial agrícola total, $\operatorname{lnSAT}$. } \\
\hline $\ln (\mathrm{SAT})$ & $\ln (e-I P A)$ & $\ln (\mathrm{TT})$ & $\ln (\mathrm{RB})$ & $\ln (\mathrm{RW})$ & Constante \\
\hline 1,000 & $-1,081$ & 0,319 & $-0,469$ & $-0,428$ & 5,957 \\
\hline \multicolumn{6}{|c|}{ Vetor de coeficientes de ajustamento normalizado $\alpha_{i 1}$} \\
\hline $\ln (\mathrm{SAT})$ & $\ln (\mathrm{e}-\mathrm{IPA})$ & $\ln (\mathrm{TT})$ & $\ln (\mathrm{RB})$ & $\ln (\mathrm{RW})$ & - \\
\hline$-0,758$ & 0,221 & 0,068 & 0,073 & 0,047 & - \\
\hline \multicolumn{6}{|c|}{ Valor do teste t de student para os coeficientes do vetor de ajustamento normalizado } \\
\hline $\ln (\mathrm{SAT})$ & $\ln (\mathrm{e}-\mathrm{IPA})$ & $\ln (\mathrm{TT})$ & $\ln (\mathrm{RB})$ & $\ln (\mathrm{RW})$ & - \\
\hline$-4,780$ & 1,812 & 0,275 & 1,423 & 0,596 & - \\
\hline
\end{tabular}

Fonte: Dados da pesquisa

A possibilidade de exogeneidade fraca para o logaritmo das variáveis taxa de câmbio efetiva real (e-IPA), termos de troca (TT), renda doméstica (RB) e renda externa $(\mathrm{RW})$, verificada pelo teste $t$ de student, sugere que o vetor de co-integração talvez possa ser interpretado como uma equação reduzida para o saldo da balança comercial agrícola total (SAT).

A estatística razão de verossimilhança (LR), apresentada na parte inferior do Quadro 6, permite que se chegue à mesma constatação, qual seja, a de que não se pode rejeitar a hipótese nula de que as variáveis termos de troca, renda doméstica e renda externa são exógenas fracas em relação ao vetor de co-integração estimado ${ }^{55}$.

55 Testes de razão de verossimilhança (aqui não reportados) aplicados individualmente para cada coeficiente de ajustamento também não rejeitam a hipótese nula de exogeneidade fraca para as variáveis taxa de câmbio efetiva real, termos de troca, renda interna e renda externa. 
Quadro 6. Teste de exogeneidade fraca para o logaritmo das variáveis (e-IPA), (TT), (RB) e (RW) em relação aos parâmetros de longo prazo.

\begin{tabular}{|c|c|c|c|c|c|}
\hline Vetor de co-i & $\begin{array}{l}\text { lo, normaliz } \\
\text { (sujeito }\end{array}$ & $\begin{array}{l}\text { variável } \\
\text { linear so }\end{array}$ & $\begin{array}{l}\text { alança co } \\
\text { metros d }\end{array}$ & $\begin{array}{l}\text { sricola tot } \\
\text { nto) }\end{array}$ & \\
\hline $\ln (\mathrm{SAT})$ & $\ln (\mathrm{e}-\mathrm{IPA})$ & $\ln (\mathrm{TT})$ & $\ln (R B)$ & $\ln (R W)$ & Constante \\
\hline 1,000 & $-0,991$ & 0,296 & $-0,498$ & $-0,339$ & 4,889 \\
\hline Vetor de coef & de ajustam & lizado (s & trições z & $x_{i l}, \operatorname{com} i$ & 4 e 5) \\
\hline $\ln (\mathrm{SAT})$ & $\ln (\mathrm{e}-\mathrm{IPA})$ & $\ln (\mathrm{TT})$ & $\ln (R B)$ & $\ln (R W)$ & - \\
\hline$-0,914$ & 0,000 & 0,000 & 0,000 & 0,000 & - \\
\hline Teste LR: $X^{2}$ & & $=0,32$ & & & \\
\hline
\end{tabular}

Fonte: Dados da pesquisa

Com o objetivo de determinar a importância das variáveis exógenas fracas no modelo de longo prazo (relação de co-integração), apresentam-se no Quadro 7 testes de restrições zero sobre os parâmetros estimados $\beta_{\mathrm{i}}$, condicionados às restrições zero já impostas aos coeficientes de ajustamento (ver Quadro 6). Os testes reportados sugerem que apenas a variável taxa de câmbio efetiva real (e-IPA) teve efeito significativo sobre o saldo da balança comercial agrícola total no longo prazo, o que pode ser observado através dos testes LR reportados no Quadro 7.

Ao nível de $5 \%$ de significância, os valores dos testes LR para restrições zero aos coeficientes associados às demais variáveis e o termo constante não são estatisticamente significantes (ver valores-p no Quadro 7). Isto é, não se pode negar a hipótese de que os coeficientes estimados associados aos logaritmos das variáveis termos de troca $(\ln T T)$, renda interna $(\ln R B)$ e renda externa $(\ln R W)$ sejam nulos. 
Quadro 7. Teste de significância para as variáveis incluídas no espaço de co-integração.

\begin{tabular}{|c|c|c|c|c|}
\hline $\begin{array}{r}\text { Vetor de co-integração, normalizac } \\
\text { (sujeito a restriç }\end{array}$ & $\begin{array}{l}\text { o para a variável } \\
\text { ses zero sobre os } \mathrm{p}\end{array}$ & $\begin{array}{l}\text { ança com } \\
\text { estimados }\end{array}$ & $\begin{array}{l}\text { rícola tota } \\
\text { com } i \neq 1)\end{array}$ & \\
\hline $\ln (\mathrm{e}-\mathrm{IPA})$ & $\ln (\mathrm{TT})$ & $\ln (\mathrm{RB})$ & $\ln (\mathrm{RW})$ & Constante \\
\hline 0,000 & 0,115 & $-0,888$ & 0,296 & $-1,820$ \\
\hline Teste LR: $X^{2}(5)=12,08$ & valor $-\mathrm{p}=0,03$ & & & \\
\hline $\ln (\mathrm{e}-\mathrm{IPA})$ & $\ln (\mathrm{TT})$ & $\ln (\mathrm{RB})$ & $\ln (\mathrm{RW})$ & Constante \\
\hline$-0,588$ & 0,000 & $-0,508$ & $-0,240$ & 3,346 \\
\hline Teste LR: $X^{2}(5)=8,86$ & valor $-\mathrm{p}=0,11$ & & & \\
\hline $\ln (\mathrm{e}-\mathrm{IPA})$ & $\ln (\mathrm{TT})$ & $\ln (\mathrm{RB})$ & $\ln (\mathrm{RW})$ & Constante \\
\hline$-1,386$ & 0,366 & 0,000 & $-1,095$ & 9,576 \\
\hline Teste LR: $X^{2}(5)=9,60$ & valor $-\mathrm{p}=0,09$ & & & \\
\hline $\ln (\mathrm{e}-\mathrm{IPA})$ & $\ln (\mathrm{TT})$ & $\ln (\mathrm{RB})$ & $\ln (\mathrm{RW})$ & Constante \\
\hline$-0,828$ & 0,294 & $-0,715$ & 0,000 & 2,620 \\
\hline Teste LR: $X^{2}(5)=5,75$ & valor $-\mathrm{p}=0,33$ & & & \\
\hline $\ln (\mathrm{e}-\mathrm{IPA})$ & $\ln (\mathrm{TT})$ & $\ln (\mathrm{RB})$ & $\ln (\mathrm{RW})$ & Constante \\
\hline$-0,536$ & 0,271 & $-0,864$ & 0,260 & 0,000 \\
\hline Teste LR: $X^{2}(5)=8,02$ & valor $-\mathrm{p}=0,16$ & & & \\
\hline
\end{tabular}

Fonte: Dados da pesquisa

Recuperando as informações apresentadas no Quadro 6, passa-se, neste momento, a analisar com mais detalhes o vetor de co-integração estimado e que, conforme sugerem os testes de exogeneidade fraca, será interpretado como uma equação reduzida de longo prazo para o saldo da balança comercial agrícola total. O vetor de cointegração estimado apresenta os seguintes coeficientes: 


$\begin{array}{cccccc}\ln (\mathrm{SAT}) & \ln (\mathrm{e}-\mathrm{IPA}) & \ln (\mathrm{TT}) & \ln (\mathrm{RB}) & \ln (\mathrm{RW}) & \text { constante } \\ 1,000 & -0,991 & 0,296 & -0,498 & -0,339 & 4,889\end{array}$

É importante estar atento para o fato de que a relação (15) está expressa na forma vetorial. Se $\ln (\mathrm{SAT})$ fosse explicitada como uma função das demais variáveis, os coeficientes teriam seus sinais trocados.

De todas as variáveis exógenas consideradas no modelo acima, o coeficiente associado à taxa de câmbio foi o que apresentou maior valor absoluto. $\mathrm{O}$ coeficiente estimado indica que, no longo prazo, uma desvalorização de $10 \%$ na taxa de câmbio efetiva real produz um aumento de aproximadamente $10 \%$ no saldo da balança comercial agrícola total.

Quando se adota o nível de 5\% de significância, os testes LR reportados no Quadro 7 não permitem negar a hipótese de que as demais variáveis não tenham apresentado efeitos sobre o saldo da balança comercial agrícola total, embora os sinais dos coeficientes a elas associados sejam os esperados. A única exceção é o coeficiente da variável termos de troca, que é negativo. Apresentam-se, a seguir, as razões econômicas para a ocorrência dessas relações no longo prazo.

\subsubsection{Efeito das desvalorizações reais do câmbio}

A desvalorização real do câmbio, ao elevar a receita de exportação, em moeda doméstica, estimula a produção interna dos bens comercializáveis internacionalmente (bens exportáveis e substitutos de importações). $\mathrm{O}$ aumento na produção é esperado em decorrência da realocação de recursos em direção ao setor exportador, que deve ocorrer a médio e longo prazos. Ademais, a possibilidade de colocar os produtos no mercado internacional a menores preços, sem afetar a receita em moeda doméstica, são indicativos de que uma desvalorização real do câmbio pode, efetivamente, aumentar a competitividade do país em transações comerciais com o exterior. 
Portanto, no longo prazo, a tendência natural é de aumento no volume exportado e decréscimo no volume importado, o que deve contribuir para melhorar o saldo da balança comercial.

\subsubsection{Efeito de uma elevação nos termos de troca}

Os termos de troca tiveram um efeito negativo, porém somente ao nível $11 \%$ de significância pode-se rejeitar a hipótese nula de que essa variável não afeta o saldo da balança comercial agrícola total no longo prazo (ver Quadro 7). Este efeito negativo dos termos de troca sobre o saldo comercial agrícola total é inconsistente com os modelos teóricos apresentados no capítulo 4.

A variável termos de troca mostrou pequena variação no período que vai de 1961 a 1975. A partir de 1976, os termos de troca passaram a apresentar maior variação $^{56}$. Quando se considera todo o período de 1961 a 1995 não se observa nenhuma tendência, crescente ou decrescente, no comportamento da série (ver Tabela 1). Talvez resulte daí a pouca significância estatística, a longo prazo, dos efeitos das variações nos termos de troca sobre o saldo comercial agrícola total.

A relação negativa encontrada entre variações nos termos de troca e saldo da balança comercial agrícola total, provavelmente, pode ser explicada por substituição no consumo, que pode ocorrer no âmbito do mercado internacional, quando o preço de uma dada cesta de produtos tende a subir em relação ao preço de uma outra cesta substituta próxima. Além do mais, uma elevação nos preços externos de uma dada cesta de produtos deve estimular a produção desses bens no resto do mundo, o que, de um lado, aumenta as opções de compras dos países importadores e, de outro, diminui ou anula as importações por parte dos países que são, ao mesmo tempo, importadores e exportadores da referida cesta de produtos. $\mathrm{O}$ efeito combinado dessas forças pode induzir uma queda, no longo prazo, do saldo da balança comercial agricola total do país, em decorrência de uma elevação sistemática em seus termos de troca.

\footnotetext{
${ }^{56}$ O desvio-padrão dos termos de troca no período de 1961 a 1975 foi de aproximadamente 9,85 , enquanto no período de 1976 a 1995 esse desvio-padrão aproxima-se de 51,66.
} 
Neste aspecto, é importante frisar que os modelos teóricos do capítulo 4 não consideram a possibilidade de substituição no consumo que pode ocorrer no âmbito do mercado internacional no longo prazo.

\subsubsection{Efeito das variações no nivel de renda interna}

Os resultados indicam que, no longo prazo, o nível de renda doméstica tem relação positiva com o saldo da balança comercial de produtos agrícolas e agroindustriais. Essa relação está coerente com a "Abordagem da Absorção" no referente ao processo de ajustamento da balança comercial (ver capítulo 4); embora não seja o que se esperaria em modelos keynesianos, como o IS-TB, mais aplicados a situações de curto prazo.

Considerando o nível de renda doméstica uma proxy de crescimento econômico do país, pode-se esperar no longo prazo que um aumento na renda doméstica (ou melhor, na produção doméstica) aumente o saldo comercial dos setores nos quais o país é mais competitivo, a menos que o crescimento do consumo doméstico seja superior ao aumento observado na renda. Um aumento de consumo superior ao aumento na renda é improvável a longo prazo (pois supõe que a propensão marginal a consumir é maior que um), principalmente tratando-se de produtos agrícolas. Acredita-se que essa tenha sido a força indutora de uma relação positiva entre a renda doméstica e o saldo da balança comercial agrícola total, constatada na presente pesquisa. Embora o efeito da renda doméstica sobre o saldo comercial agrícola total tenha sido positivo no longo prazo, somente ao nível de $9 \%$ de significância é que se pode rejeitar a hipótese nula de que essa variável não afeta o saldo da balança comercial agrícola total.

Portanto, a contração no nível de renda doméstica, com o propósito de melhorar o saldo comercial, não pode ser generalizada para todos os setores da economia. Uma política não seletiva pode ter efeito contrário ao desejado, caso os setores de bens exportáveis sejam igualmente afetados, e a contração na demanda por importações, nos setores onde o país não é competitivo, não seja suficiente para compensar essa perda. 
Uma combinação de política que provoque uma contração na renda doméstica e, simultaneamente, incentive a renda dos setores de bens exportáveis, notadamente daqueles que são competitivos internacionalmente, seria o desejável. A exemplo, pode-se citar a política recessiva implementada pelo governo em 1981, que foi seguida por grandes incentivos financeiros às exportações de produtos agropecuários e extrativa vegetal e animal ${ }^{57}$. Como resultado dessa combinação de política, foi possível obter uma melhora no saldo comercial do país naquele ano, apesar da recessão mundial que vigorou no período de 1980 a 1982.

\subsubsection{Efeito das variações no nível de renda externa}

Apesar do efeito do nível de renda externa sobre o saldo da balança comercial agrícola total ter sido o esperado pela literatura de comércio exterior (impacto positivo), o mesmo foi estatisticamente pouco significativo. Isto revela que, mantida a atual política de comércio exterior do país, não é esperado, a longo prazo, que um aumento no valor das importações do resto do mundo seja acompanhado por uma melhora no saldo da balança comercial agrícola total do Brasil.

\subsection{Modelo de correção de erros}

A dinâmica de curto prazo do saldo da balança comercial agrícola total é apresentada na Tabela 5. A equação estimada inclui como variáveis explicativas, além da variável endógena em diferença defasada, o termo de correção de erros defasado de um período (correspondente ao vetor de co-integração do Quadro 6, reproduzido também na expressão (15) e as diferenças (correntes e defasadas) das variáveis: taxa de câmbio efetiva real $(\operatorname{lne}-\mathrm{IPA})$; termos de troca $(\ln \mathrm{TT})$; renda interna $(\ln R B)$ e externa $(\ln R W)^{58}$.

\footnotetext{
${ }^{57}$ Um estudo desenvolvido por Pinheiro et al (1993) aponta que ao longo do período de 1980 a 1991 , os anos de 81 a 83 foram os que concentraram os maiores incentivos financeiros às exportações de produtos agropecuários, extrativa vegetal e animal.

${ }^{58}$ A única variável corrente significativa no modelo de correção de erros foi a primeira diferença da renda do resto do mundo. Levando-se em conta que o Brasil tem participação marginal no valor das importações mundiais, decidiu-se pressupor que tal variável seja também exógena em relação ao modelo de curto prazo.
} 
Uma variável binária (D) de intervenção para os anos de 1976 e 1977 também foi incluída para captar o efeito da geada de 1975 sobre os preços internacionais de café e, consequentemente, sobre o saldo da balança comercial agrícola total.

Tabela 5. Estimativa da equação de correção de erros para o saldo da balança comercial agrícola total do Brasil [variável dependente: $\Delta(\operatorname{lnSAT})]$ - 1963 a 1995.

\begin{tabular}{|c|c|c|c|c|}
\hline Variável & $\begin{array}{c}\text { Coeficiente } \\
\text { estimado }\end{array}$ & Teste $\mathrm{t}\left(\mathrm{t}_{\mathrm{c}}\right)$ & $\begin{array}{c}\text { Probabilidade de } \\
|t|>\left|t_{c}\right|\end{array}$ & Testes de diagnóstico \\
\hline$\Delta\left(\operatorname{lnSAT} T_{t-1}\right)$ & 0,287 & $1,900^{\text {ns }}$ & 0,07 & Observações (n) .....................................33 \\
\hline$\Delta\left(\operatorname{lne}-\mathrm{IPA}_{U}\right)$ & 0,400 & $1,640^{\mathrm{ns}}$ & 0,12 & Grau de liberdade \\
\hline$\Delta\left(\operatorname{lne}-\mathrm{IPA}_{t-1}\right)$ & $-0,013$ & $-0,050^{\text {ns }}$ & 0,96 & 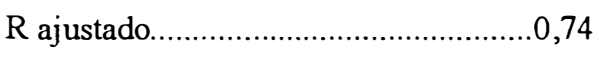 \\
\hline$\Delta\left(\operatorname{lnTT_{t})}\right.$ & $-0,149$ & $-1,114^{\mathrm{ns}}$ & 0,28 & DW \\
\hline$\Delta\left(\ln T T_{t-1}\right)$ & 0,176 & $1,727^{\text {ns }}$ & 0,10 & 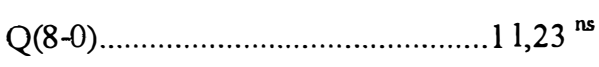 \\
\hline$\Delta\left(\operatorname{lnRB} B_{t}\right)$ & 0,268 & $0,465^{\text {ns }}$ & 0,65 & \\
\hline$\Delta\left(\operatorname{lnRB_{t-1}}\right)$ & 1,289 & 2,093 & 0,05 & \\
\hline$\Delta\left(\operatorname{lnR} W_{1}\right)$ & 0,953 & 2,416 & 0,03 & \\
\hline$\Delta\left(\ln R W_{t-1}\right)$ & $-0,565$ & $-1,194^{\text {ns }}$ & 0,25 & \\
\hline$D_{t}$ & 0,226 & $1,951^{\mathrm{ns}}$ & 0,07 & \\
\hline$u_{t-1}$ & $-0,914$ & $-5,311$ & 0,01 & \\
\hline
\end{tabular}

Hipóteses nulas testadas: os coeficiente associados às seguintes variáveis são zero:

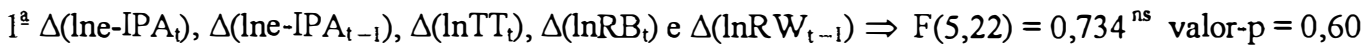

$2^{\underline{a}} \quad \Delta($ lne-IPA $), \Delta\left(\operatorname{lnTT}_{t-1}\right)$ e $D t \Rightarrow F(3,22)=3,742$ valor $-\mathrm{p}=0,03$

$3^{\mathrm{a}} \quad \Delta\left(\operatorname{lne}^{-}-\mathrm{IPA}_{\mathrm{t}}\right)$ e $\Delta\left(\operatorname{lnTT}_{\mathrm{t}-1}\right) \Rightarrow \mathrm{F}(2,22)=3,184$ valor $-\mathrm{p}=0,07$

Fonte: Dados da pesquisa

Observa-se na Tabela 5 que apenas três variáveis apresentaram efeitos estatisticamente significativos ao nível de 5\%: a primeira diferença corrente da renda do resto do mundo; a primeira diferença defasada (de um período) da renda interna; e o termo de correção de erros correspondente ao vetor de co-integração (expressão 15). Os efeitos da variável binária e da variável endógena defasada foram significativos apenas ao 
nível de $7 \%$, enquanto que a primeira diferença defasada (de um período) dos termos de troca somente acusa efeito sobre o saldo da balança comercial agrícola total se o nível de significância adotado for de10\%.

$O$ teste $F$ rejeita a hipótese nula de que os efeitos das variáveis taxa de câmbio (em sua primeira diferença corrente), termos de troca (considerados em sua primeira diferença defasada) e binária possam ser considerados nulos no modelo de curto prazo, de modo que se decidiu mantê-las na equação (ver Tabela 5). As demais variáveis tiveram efeitos nulos, conforme pode ser constatado pelo teste F. Entre elas, destacandose a taxa de câmbio efetiva real (tomada em sua primeira diferença defasada).

Uma explicação para o efeito pouco significante, estatisticamente, da variável taxa de câmbio efetiva real sobre o saldo da balança comercial agrícola total, a curto prazo, está nas baixas elasticidades-preço da oferta dos principais produtos da pauta de exportações e da demanda de importações agrícolas do país.

Do lado das exportações, tem-se que a produção agrícola e a oferta de produtos derivados da agricultura respondem com uma certa defasagem a estímulos de preço. Portanto, mesmo considerando que ocorra um incremento residual das exportações oriundas de escoamento de estoques, notadamente por parte dos produtos agrícolas processados, é provável que o mesmo não seja significativo a curto prazo.

Sabe-se que a demanda por importações brasileiras de produtos da agricultura é de baixa elasticidade-preço. Por exemplo, podem-se citar os casos de trigo e malte (produtos de grande peso em nossa pauta de importações), em que as variações de preços em moeda local têm pouco efeito, pelo menos a curto prazo, sobre as quantidades importadas, uma vez que a oferta interna não satisfaz à demanda doméstica pelos referidos produtos.

Por essa razão, o maior efeito a curto prazo de uma desvalorização real do câmbio sobre o setor agrícola exportador é elevar o valor unitário, em moeda doméstica, das exportações, com pouco efeito sobre o volume exportado e, consequentemente, sobre a competitividade externa do setor (aqui entendida como a capacidade do setor em aumentar seu saldo de comércio). Não obstante, a perda cumulativa de receita de exportação, em moeda doméstica, decorrente da valorização real do câmbio, fatalmente 
terá um efeito negativo e significativo no longo prazo sobre o volume exportado e, consequentemente, sobre o saldo da balança comercial (conforme constatado na presente pesquisa).

Apresentamos na Tabela 6 uma versão parcimoniosa da equação de curto prazo para o saldo da balança comercial agrícola total, na qual as variáveis não significantes estatisticamente (identificadas pela estatística F) são excluídas. Tais variáveis

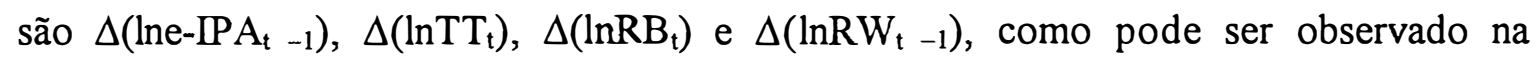
Tabela 5 .

Tabela 6. Estimativa da equação de correção de erros, versão parcimoniosa, para o saldo da balança comercial agrícola total do Brasil (variável dependente:ln $\Delta$ SAT) - 1963 a 1995.

\begin{tabular}{|c|c|c|c|c|}
\hline Variável & $\begin{array}{c}\text { Coeficiente } \\
\text { estimado }\end{array}$ & $\begin{array}{c}\text { Teste } t \\
\left(t_{c}\right)\end{array}$ & $\begin{array}{c}\text { Probabilidade de } \\
|t|>\left|t_{c}\right|\end{array}$ & Testes de diagnóstico \\
\hline$\Delta\left(\operatorname{lnSAT} T_{t-1}\right)$ & 0,236 & $1,827^{155}$ & $\overline{0,08}$ & Observações (n) ... \\
\hline$\Delta\left(\ln e-I_{P A}\right)$ & 0,295 & $1,411^{\mathrm{ns}}$ & 0,17 & Grau de liberdade \\
\hline$\Delta\left(\operatorname{lnTT_{t-1}}\right)$ & 0,200 & 2,191 & 0,04 & $.0,72$ \\
\hline$\Delta\left(\operatorname{lnRB} B_{t-1}\right)$ & 1,253 & 2,940 & 0,01 & 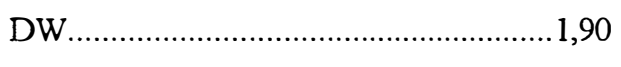 \\
\hline$\Delta\left(\operatorname{lnR} W_{t}\right)$ & 0,785 & 2,350 & 0,03 & 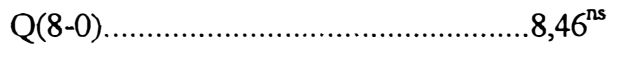 \\
\hline$D_{t}$ & 0,179 & 2,041 & 0,06 & \\
\hline$u_{t-1}$ & $-0,908$ & $-6,897$ & 0,01 & \\
\hline
\end{tabular}

Fonte: Dados da pesquisa

O coeficiente estimado para a variável $\left[\Delta\left(\operatorname{lne}-\left[P A_{t}\right)\right]\right.$ teve o sinal positivo (coerente com o encontrado no longo prazo), mas revelou-se pouco significativo estatisticamente (Tabela 6).

Como enfatizado anteriormente, a oferta de produtos agrícolas (insumos para os produtos agroindustriais) responde com uma certa defasagem a estímulos de preços, mas o faz de forma cumulativa. Essa defasagem decorre do lapso de tempo entre variações nos preços e alteração na produção, que é necessário para que o volume exportado aumente ou diminua e, assim, afete o saldo comercial. Provavelmente, o número de defasagens utilizado para a variável taxa de câmbio efetiva real na estimação 
do modelo de correção de erros (um na primeira estimativa, ver Tabela 5, e zero na segunda estimativa, ver Tabela 6) não tenha sido suficiente para que o volume exportado respondesse às desvalorizações reais do câmbio. Essa é uma explicação para o efeito (direto) estatisticamente pouco significativo, a curto prazo, das variações na taxa de câmbio efetiva real sobre o saldo da balança comercial agrícola total a curto prazo.

De fato, o efeito estatisticamente significativo, a longo prazo, da variável taxa de câmbio real sobre o saldo da balança comercial agrícola total, revela que as desvalorizações reais do câmbio têm efeito cumulativo sobre esse saldo.

Os coeficientes estimados (ver Tabela 6) sugerem que um aumento de $10 \%$ nas variações dos termos de troca $\left[\Delta\left(\ln \mathrm{TT}_{\mathrm{t}-1}\right)\right]$ e nas variações da renda interna


aproximadamente $2 \%$ e $12,53 \%$, respectivamente, no saldo da balança comercial agrícola total $^{59}$.

Considerando que a oferta de produtos da agricultura é dada no curto prazo e que a mudança de hábito alimentar da população é um processo de médio e longo prazos, então os efeitos adversos que poderiam operar no longo prazo sobre o saldo comercial, em decorrência de uma elevação nos termos de troca do país, conforme discutido no subitem 6.2.2, são muito mais fracos no curto prazo. Mesmo que a quantidade exportada pelo Brasil não aumente no curto prazo, ainda assim é esperado que uma elevação nos preços externos dos bens que o país exporta, comparativamente aos bens que o país importa, tende a melhorar o saldo comercial no curto prazo.

Observa-se também na Tabela 6 que um aumento de 10\% nas variações da renda do resto do mundo $\left[\Delta\left(\operatorname{lnR} W_{t}\right)\right]$ produz, no mesmo período, uma variação de $7,85 \%$ sobre o saldo da balança comercial agrícola total.

\footnotetext{
${ }^{59}$ Castro e Cavalcante (1997, p. 18) denominam de taxa de crescimento as variações no logaritmo das variáveis incluídas no modelo de correção de erros. Se essa denominação fosse adotada para o caso em análise, então os coeficiente estimados (ver Tabela 6) estariam indicando que um aumento de $10 \%$ na taxa de crescimento dos termos de troca e na taxa de crescimento da renda doméstica produzem, no período seguinte, um aumento de $2 \%$ e $12,53 \%$, respectivamente, na taxa de crescimento do saldo da balança comercial agrícola total.
} 
O termo de correção de erros $\left(\mathrm{u}_{\mathrm{t}-1}\right)$ é estatisticamente significativo ao nível de $1 \%$ de significância e apresenta sinal negativo nas duas equações (ver Tabelas 5 e 6). O sinal negativo associado ao termo de correção de erros sugere que se o valor do saldo da balança comercial agrícola total ultrapassar seu nível de equilíbrio de longo prazo (no período anterior) o mesmo deverá cair em direção a esse nível de equilíbrio no período corrente. Ou seja, o saldo da balança comercial agrícola total converge para o equilíbrio de longo prazo após a ocorrência de um choque, a uma velocidade média de 0,908 por ano. Isto é, a correção anual causada no saldo da balança comercial agrícola total em direção ao equilíbrio de longo prazo é de aproximadamente $91 \%$ (ver Tabela 6).

Ademais, com base em Castro e Cavalcante (1997, p. 18), pode-se ainda ter a seguinte interpretação para o coeficiente associado ao termo de correção de erros (defasado de um período): ele mostra que um desvio de $10 \%$, em determinado período, em relação aos valores de equilíbrio de longo prazo das variáveis saldo da balança comercial agrícola total, taxa de câmbio efetiva real, termos de troca, renda interna e renda externa produzem (no período seguinte) uma variação compensatória na taxa de crescimento do saldo da balança comercial agrícola total de aproximadamente 9,1\%. Portanto, percebe-se que a taxa de câmbio efetiva real pode produzir efeito sobre o saldo da balança comercial agrícola total a curto prazo, embora o faça de forma indireta através do termo de correção de erros.

Por fim, verifica-se também que a curto prazo o choque resultante da geada de 1975 sobre os cafezais do Brasil teve um efeito positivo e estatisticamente significativo (ao nível de 6\%) sobre o saldo da balança comercial agrícola total. 


\section{CONCLUSÕES}

O objetivo geral desta pesquisa foi determinar os efeitos de curto e longo prazos da taxa de câmbio efetiva real e de outras variáveis macroeconômicas sobre o saldo da balança comercial de produtos agrícolas e agroindustriais do Brasil, considerando o período de 1961 a 1995.

Os resultados encontrados indicam que a longo prazo as desvalorizações efetivas reais do câmbio têm maior efeito (positivo) e estatisticamente significativo sobre o saldo da balança comercial agrícola total do que as demais variáveis consideradas (renda interna, renda externa e termos de troca). Considerando que foram os setores agrícola e agroindustrial que asseguraram os maiores superávits na balança comercial do país, e que a perda cumulativa de receita real, em moeda doméstica, decorrente da valorização real do câmbio, fatalmente terá um efeito negativo e significativo no longo prazo sobre o volume exportado e, consequentemente, sobre o saldo da balança comercial agrícola total, torna-se necessário acelerar o processo de correção da atual defasagem da taxa de câmbio efetiva real ${ }^{60}$.

A curto prazo, as variáveis mais relevantes para "explicar" as variações diretas observadas no saldo da balança comercial agrícola total são (do ponto de vista estatístico): renda interna, defasada de um período; renda externa, no período corrente; termos de troca, com uma defasagem; e, o termo de correção de erros (os desvios em relação ao equilibrio de longo prazo). A variável taxa de câmbio efetiva real, no período corrente, também apresenta efeito positivo sobre o saldo da balança agrícola total

\footnotetext{
${ }^{60}$ Outros fatores fundamentais também apontam para o desalinhamento da atual taxa real de câmbio vigente no País; dentre eles destacam-se: i) o elevado diferencial entre as taxas reais de juros doméstica e externa; ii) uma taxa de crescimento do PIB bem abaixo de sua média histórica (que é de $8 \%$ ao ano); e, iii) os elevados déficits na conta corrente do balanço de pagamentos registrados em 1995, 1996 e 1997.
} 
(coerente com o esperado), mas tal efeito não teve bom nível de significância estatística. O maior efeito, a curto prazo, da taxa de câmbio efetiva real sobre o saldo da balança comercial agrícola total ocorre de forma indireta através do seu impacto sobre o termo de correção de erros.

É importante atentar para a seguinte questão: o fato das variações na taxa de câmbio efetiva real não apresentarem bom nível de significância estatística na equação de curto prazo não significa dizer que as mesmas não afetam diretamente o saldo da balança comercial agrícola total a curto prazo. A oferta de produtos agrícolas (insumos para os produtos agroindustriais) responde com uma certa defasagem a estímulos de preços, mas o faz de forma cumulativa. Essa defasagem decorre do lapso de tempo entre variações nos preços e alteração na produção, que é necessário para que o volume exportado aumente ou diminua e, assim, afete o saldo comercial. Um ano de defasagem para a variável taxa de câmbio efetiva real, provavelmente, não foi suficiente para que o volume exportado respondesse às desvalorizações reais do câmbio. Essa é uma explicação para o efeito estatisticamente pouco significativo, a curto prazo, das variações na taxa de câmbio efetiva real sobre o saldo da balança comercial agrícola total.

O efeito positivo da variável renda interna sobre o saldo da balança comercial agrícola total sugere que, se dependesse apenas da agricultura e da agroindústria, o governo não necessitaria implementar políticas recessivas com o objetivo de melhorar o saldo total da balança comercial a curto prazo. As políticas que visam reduzir o nível de renda doméstica com o propósito de melhorar o saldo da balança comercial, frequentemente utilizadas, deveriam ser acompanhadas de medidas compensatórias para estimular a renda dos setores de bens exportáveis, notadamente dos mais competitivos internacionalmente ${ }^{61}$.

Uma política não seletiva pode ter efeito contrário ao desejado, caso os setores de bens exportáveis da economia sejam também afetados. Desse modo, a política

\footnotetext{
${ }^{61}$ Atualmente este é o tipo de política que o Governo vem adotando com o propósito de equilibrar suas contas externas, qual seja: um conjunto de medidas visando estimular a exportação e provocar uma desaceleração no nível de atividade doméstica.
} 
de contração de renda deveria ser seguida de políticas compensatórias que estimulassem a produção nos setores de bens exportáveis.

Quanto aos efeitos da variável renda externa (na presente pesquisa representada pelo valor das importações do resto do mundo de produtos agrícolas e agroindustriais) são relevantes as considerações, a seguir sintetizadas. Somente a curto prazo se verificou efeito estatisticamente significativo das variações no valor das importações do resto do mundo sobre o saldo da balança comercial agrícola total. A ausência desse efeito, a longo prazo, chama a atenção para a passividade de nossa política de comércio exterior. Nesse sentido, o Brasil deve por em prática uma política comercial mais agressiva, na tentativa de acompanhar a tendência de crescimento, a longo prazo, observada no valor das importações de produtos agrícolas e agroindustriais do resto do mundo.

No que concerne à variável termos de troca, deve-se atentar para duas questões essenciais. Sendo exógenos os preços externos dos bens que o Brasil exporta e importa, o saldo da balança agrícola total passa a ser dependente da trajetória de curto e longo prazos dos referidos preços, não podendo, portanto, os formuladores de políticas agrícolas e macroeconômicas do País interferirem no processo. Por outro lado, como grande parte dos produtos agrícolas não processados que compõem a pauta de exportação e importação do país são reconhecidamente de baixa elasticidade-preço da demanda, os termos de troca podem variar muito com as quantidades transacionadas no mercado. Em outras palavras, num horizonte temporal mais longo não há como prever com segurança o comportamento dessa importante relação.

A presente pesquisa também evidencia que, dada a importância do complexo agroindustrial brasileiro como exportador líquido, não se pode desconsiderar sua contribuição para equilibrar a balança comercial total, ainda mais quando se tem conhecimento que os maiores déficits no balanço de pagamentos ocorreram em épocas de déficits comerciais ${ }^{62}$.

\footnotetext{
${ }^{62}$ Esta observação já tinha sido feita por Homem de Melo \& Zockun em 1976 e por Veiga em 1977, e ainda hoje continua válida.
} 
Atualmente, técnicos do Ministério da Fazenda também compartilham dessa constatação. Dados divulgados pelo jornal Gazeta Mercantil de 13 de janeiro de 1997 revelam que o saldo da balança comercial agrícola total em 1996 foi de US\$10,44 bilhões, contra um déficit US\$ de 5,53 bilhões registrado na balança comercial. Portanto, o que se vem observando é a manutenção da tendência típica do período de 1961 a 1995, com a agricultura e a agroindústria gerando superávits em sua balança comercial e os demais setores da economia contribuíndo para a elevação do déficit em transações comerciais com o exterior.

Como eventual limite aos resultados econométricos da pesquisa, deve-se atentar para o fato de que o tamanho da amostra utilizada não é grande. Isso significa que a distribuição assintótica das estatísticas posto e os testes de raiz unitária podem não ser muito precisos.

Se este for o caso, as considerações feitas sobre as implicações econômicas, notadamente as de longo prazo, devem ser interpretadas com alguma cautela $^{63}$. Por outro lado, as variáveis de política econômica (taxa de câmbio e renda doméstica) exerceram influência apreciável sobre o saldo da balança comercial de produtos agrícolas e agroindustriais e, ao que tudo indica, as relações econômicas propostas pela teoria foram devidamente captadas pelas estimativas. Ademais, o período de 1961 a 1995 registrou profundas transformações na economia brasileira e, em especial, em seu comércio exterior, compatíveis com situações de longo prazo.

${ }^{63}$ O Prof. Bent Nielsen da Universidade de Oxford sugere que se faça uma análise das implicações econômicas quando se usa pequenas amostras para estimar vetores co-integrados (comunicação pessoal). Para a mesma questão ver também Mark (1990, p. 135). 


\section{REFERÊNCIAS BIBLIOGRAFIAS}

A ALAVANCAGEM da agricultura (editorial). Gazeta Mercantil, São Paulo, 13 jan. 1997. p. A-2.

ALEXANDER, S. Effects of a devaluation on a trade balance. IMF Staff Papers, v. 2, p. 263-279, Apr. 1952.

ALMEIDA, C. O. de. Política cambial e receita de exportação de café do Brasil - 1970 a 1989. Fortaleza, 1993. 66p. Dissertação (Mestrado) - Universidade Federal do Ceará.

ALMEIDA, C. O. de; MESQUITA, T. C. Causalidade entre preços externos e quantidades exportadas de café do Brasil no mercado internacional - 1965/89. Pesquisa e Planejamento Econômico, v. 25, n. 3, dez. 1995.

ALMEIDA, C. O. de; BACHA, C. J. C. Evolução do saldo da balança comercial brasileira no período de 1961 a 1996. Preços Agrícolas, n. 134, dez. 1997. p. 16-19.

ALMONACID, R. D. Sugestões para uma nova política de minidesvalorizações cambiais.

Revista Brasileira de Economia,v. 33, n.2, p. 287-299, abr./jun. 1979.

BACHA, E. L. Sobre a taxa de câmbio: um adendo ao artigo de Pastore-Barros-Kadota. Pesquisa e Planejamento Econômico, v. 7, n. 1, p. 237-244, abr. 1977.

BARROS, G. S. de C. Efeitos de políticas macroeconômicas sobre a agricultura brasileira. Piracicaba: ESALQ/FEALQ/Ministério da Economia, Fazenda e Planejamento, 1990. p. 12-23. (Relatório de Pesquisa).

BAER, W. A industrialização e o desenvolvimento econômico do Brasil. 6. ed. Rio de Janeiro: FGV, 1985. 593p.

BLUMENSCHEIN, F. A integração do mercado financeiro brasileiro durante o período 1978/90. Pesquisa e Planejamento Econômico, v. 25, n. 3, p. 449-478, dez. 1995. 
BONTEMPO, H. C. Política cambial e superávit comerciais. Pesquisa e Planejamento Econômico,v. 19, n.1, p. 45-64, abr. 1989.

BOUCHER, J. The U.S. current account: a long and short run empirical perspective. Souther Economic Journal, v.58, n.1, p. 93-111, July 1991.

BRAGA, H. C.; MARKWALD, R. A. Funções de oferta e de demanda das exportações de manufaturados no Brasil: estimação de um modelo simultâneo. Pesquisa e Planejamento Econômico,v. 13, n. 3, p. 707-744, dez. 1983.

BRAGA, H.; ROSSI, J. A Dinâmica da balança comercial no Brasil, 1970/1984. In: ENCONTRO BRASILEIRO DE ECONOMETRIA, 8. , Brasília, 1986. Anais. Rio de Janeiro: SBE, 1986, v. 2, p. 145-160.

BRANSON, W.H.; LITVACL, J. M. Macroeconomia. São Paulo: Harbra, 1978. 432p.

CARDOSO, E. A. Taxas cambiais fixas e flexíveis e a oferta de alimentos: um comentário. Pesquisa e Planejamento Econômico, v. 9, n. 3, p. 885-894, dez. 1979.

CARDOSO, E. A. Implicações de uma desvalorização cambial no Brasil. Estudos Econômicos, v. 11, n. 2, p.143-154, abr./jun. 1981.

CARVALHO, M. A. de. Taxa de câmbio e receita das exportações agrícolas. In: Anais do Congresso Brasileiro de Economia e Sociologia Rural, 33., 1995. Anais Brasilia: SOBER, v. 1, p. 236-251. 1995.

CASTRO, A. S. de; CAVALCANTE, M. A. F. H. Estimação de equações de exportação e importação para o Brasil - 1955/95. Textos para Discussão. IPEA, n. 469, mar. 1997.

CLEMENT, M. O.; PFISTER, R. L.; ROTHWELL, R.L. Theoretical issues in international economics. New York: Houghton Mifflin Company, 1967. p. 284-350.

CONJUNTURA ECONÔMICA. Rio de Janeiro, v. 30, n. 5, p. 88-101, maio 1976.

CONJUNTURA ECONÔMICA. Rio de Janeiro, n. 4, p. 18, abr. 1997.

DICKEY, D. A.; FULLER, W. A. Likelihood ratio statistics for autoregressive time series with a unit root. Econometrica, v. 49, n. 4, p.1057-1072, Jul. 1981. 
DORNBUSCH, R. Open Economy Macroeconomics. New York:BasicBook, 1980. $293 \mathrm{p}$.

DORNBUSCH, R.; FISCHER, S. Macroeconomia. São Paulo: Makron, 1991. 930 p.

ENDERS, W. Rats handbook for econometric time series. New York: John wiley \& Sons, Inc. 1996.

ENGLE, R. F.; GRANGER, C. W. J. Cointegration and error correction: representation, estimation and testing. Econometrica, v. 55, n.2, p. 251-276, March. 1987.

ENGLE, R. F.; HENDRY, D. F.; RICHARD, J. F. Exogeneity. Econometrica, v. 51, n. 2, p. 277-304, 1983.

FERREIRA, A. H. B. Teste de cointegração e um modelo de correção de erros para a balança comercial brasileira. Estudos Econômicos, v. 23, n. 1, p. 35-65, jan./abr. 1993.

FULLER, W. A. Introduction to statistical time series. New York: John Wiley \& Sons, 1976.

GONZALO, J. Five alternative methods of estimating long-run equilibrium relationships. Journal of Econometrics, v. 60, p. 203-233, 1994.

GRANGER, C. Developments in the study of cointegrated economic variables. Oxford Bulletin of Economics and Statistics, v. 48, n. 3, p. 213-228, 1986.

GUIMARÃES, C. V.; OLIVEIRA, I. C. Plano de estabilização e comércio exterior agrícola. In: CONGRESSO BRASILEIRO DE ECONOMIA E SOCIOLOGIA RURAL, 28., Florianópolis, 1990. Anais. Brasília: SOBER, 1990. v.1, p. 329-341.

GUJARATI, D. N. Basic Econometrics. 3. ed. New York: McGraw-Hill, 1995.

HAMILTON, J. D. Time series analysis. Princeton: Princeton University Press, 1994. $799 \mathrm{p}$.

HANSEN, H.; JUSELIUS, K. Cats in Rats - Cointegration analysis of time series. Estima. Evanston, Illinois, 1995.

HARBERGER, A. Currency depreciation, income and the balance of trade. Journal of Political Economy, n. 58, 1950. p. 47-60. 
HARRIS, R. I. D. Using cointegration analysis in econometric modelling. London: Prentice Hall/Harvester Wheatsheaf, 1995. 176 p.

HAUG, A. A. Tests for cointegration a Monte Carlo comparison. Journal of Econometrics, v. 71, p. 89-115, 1996.

HOFFMANN, R. Estatística para economista. 2. ed. São Paulo: Pioneira, 1991. 426p.

HOMEM DE MELO, F. B.; ZOCKUN, M. H. Exportações agrícolas, balanço de pagamentos e abastecimento do mercado interno. Estudos Econômicos, v. 7, n. 2, p. 9-50, 1977.

HORTA, M. H.; PIANI, G.; KUME, H. A política cambial e comercial. In: IPEA. Perspectiva da Economia Brasileira - 1992. Rio de Janeiro: IPEA, 1993. p. 59-79.

IMF. International Financial Statistics Yearbook. Washington: IMF, 1997.

JOHANSEN, S. Statistical analysis of cointegration vectors. Journal of Economic Dynamics and Control, v. 12, n. 2/3, p. 231-254, Jun./Set. 1988.

JOHANSEN, S. Estimation and hypothesis testing of cointegration vectors in gaussian vector autoregressive models. Econometrica, v. 59, n. 6, Nov., p. 1551-1580, 1991.

JOHANSEN, S. Determination of cointegration rank in the presence of a linear trend, Oxford Bulletin of Economics and Statistics, v. 54, 383-97, 1992.

JOHANSEN, S. Cointegration in partial systems and the efficiency of single-equation analysis. Journal of Econometric, v. 52, p. 389-402, 1992.

JOHANSEN, S.; JUSELIUS, L. Maximum likelihood estimation and inference on cointegration with aplications to the demand for money. Oxford Bulletin of Economics and Statistics, v. 52, n. 2, p. 169-210, 1990.

LOCATELLI, R. L.; SILVA, J. A. B. Câmbio real e competitividade das exportações brasileiras. Revista Brasileira de Economia, v. 45, n. 4, p. 543-564, out./dez. 1991.

LIU, D. J.; CHUNG, P. J.; MEYERS, W. H. The impact of domestic and foreign macroeconomic variables on U.S. meat exports. Agricultural and Resource Economics Review, v. 22, n. 2: p. 210-221, 1993.

MARK, N. C. Real and nominal exchange rates in the long run: an empirical investigation. Journal of International Economics, v. 28, p. 115-136, 1990. 
MARTNER, R. Efeitos macroeconômicos de uma desvalorização cambial: análise de simulação para o Brasil. Pesquisa e Planejamento Econômico, v. 22, n. 1, p. 3572, abr. 1992.

MENDONÇA DE BARROS, J. R. de. et al. Sistemas fiscais e incentivos às exportações. Revista Brasileira de Economia,v. 29, n. 4, p. 3-24, out./dez. 1975.

NEVES, R. B. Composição das exportações brasileiras e estabilidade da receita de exportações. Pesquisa e Planejamento Econômico, v. 14, n. 3, p. 659-688, dez. 1984.

NUNES, J. M. M. Balança comercial e taxa de câmbio real: uma análise de cointegração. Revista de Economia Política, v. 14, n. 1, p. 53-62, jan./mar. 1994.

OSTERWALD-LENUM, M. A note with quantiles of asymptotic distribution of the ML cointegration rank test statistics. Oxford Bulletin fo Economics and Statistics, v. 54, n. 3, p. 461-472, 1992.

PASTORE, A. C. et al. A teoria da paridade do poder de compra, minidesvalorizações e o equilíbrio da balança comercial brasileira. Pesquisa e Planejamento Econômico, v. 6, n. 2, p. 287-312, ago. 1976.

PASTORE, A. C., et al. Sobre a taxa de câmbio: resultados adicionais e uma réplica à análise de Bacha. Pesquisa e Planejamento Econômico, v. 8, n. 2, p. 457-474, ago. 1978 .

PEREIRA, L. V. Esperada valorização da taxa de câmbio. Rio de Janeiro. Conjuntura Econômica, v. 48, n.7, p.22-23, jul. 1994.

PINHEIRO, A. C. ; HORTA, M. H. A competitividade das exportações brasileiras no período 1980/88. Pesquisa e Planejamento Econômico, v. 22, n. 3, p. 437-474, dez. 1992.

PINHEIRO, A. C. et al. Composição setorial dos incentivos às exportações brasileiras.

Revista Brasileira de Economia, v. 47, n. 4, p. 473-501, out./dez. 1993.

RELATÓRIO DO BANCO CENTRAL DO BRASIL - 1994. Brasília, 1995.

RELATÓRIO DO BANCO CENTRAL DO BRASIL - 1995. Brasília, 1996. 
RIOS, S. M. C. P. Exportações brasileiras de produtos manufaturados: uma avaliação econométrica para o período 1964/84. Pesquisa e Planejamento Econômico, v.17, n.2, ago. 1987.

RIVERA-BATIZ, F. L.; RIVERA-BATIZ, L. A. International Financial And Open Economy Macroeconomics. 2. ed. New York: Macmillan, 1994. 676p.

ROSE, A. The role of exchange rates in a popular model of international trade - Does the "Marshall-Lerner" condition hold? Jounal of International Economics, v. 30, p. 301-316, 1991.

SAYAD, J. Taxas cambiais fixas e flexíveis e a oferta de alimentos. Pesquisa e Planejamento Econômico, v. 9, n. 2, p. 351-378, ago. 1979a.

SAYAD, J. Taxas cambiais fixas e flexíveis e a oferta de alimentos: Réplica. Pesquisa e Planejamento Econômico, v. 9, n. 3, p. 895-898, dez. 1979 b.

SCHUH, G. E. A política cambial e o desenvolvimento da agricultura no Brasil: In: REUNIÃO ANUAL DA SOCIEDADE BRASILEIRA DE ECONOMIA RURAL, 14., Vitória, 1976. Anais. Viçosa: SOBER, 1977, t. 3, p.3-24.

SCHUH, G. E. Taxa de câmbio e agricultura dos Estados Unidos. In: ARAUJO, P. F. C.; SCHUH, G. E. Desenvolvimento da agricultura - Estudos de casos. São Paulo: Pioneira, 1983. p. 89-109.

SENNA, J. J. Notas sobre a origem do sistema de minidesvalorizações. Revista Brasileira de Economia, v. 28, n. 2, p. 29-35, abr./jun. 1974.

SILVA, A. M. da. Bases da política de minidesvalorizações. Estudos Econômicos, v. 6, n. 1, p. 97-112, 1976.

SILVA, J. A. B.; Locatelli, R. L. Câmbio e custo das exportações no Brasil. In: ENCONTRO NACIONAL DE ECONOMIA, 15., Salvador, 1987. Anais. Salvador: ANPEC, 1987. v. 1, p. 369-388.

SODERSTEN, B. Economia internacional. Rio de Janeior: Interciência, 1979. pp. 257 280. 
SUPLICY, E. M. Os efeitos das minidesvalorizações na economia brasileira. Rio de Janeiro: FGV, 1976.

TEIXEIRA, E. C; ROCHA, L. E. V. Taxa de câmbio e competitividade da economia brasileira. In: Anais do XXXIII Congresso Brasileiro de Economia e Sociologia Rural, v. 2. Brasília, SOBER, 1995, p. 200-219.

TYLER, W. G. O viés antiexportador em políticas comerciais e o desempenho das exportações: alguns aspectos da recente experiência brasileira. Revista Brasileira de Economia, v. 36, n. 2, p. 183-196, abr./jun. 1982.

VEIGA, A. A agricultura e o balanço de pagamentos, 1946-75. In: REUNIÃO ANUAL DA SOCIEDADE BRASILEIRA DE ECONOMIA RURAL, 14., Vitória, 1976. Anais. Viçosa: SOBER, 1977, t. 3, p. 57-70.

VIANA, G. C. Tasa de câmbio real efectiva y exportaciones brasileñas de productos manufacturados. Caderno de Economia n.14, dez. 1993.

WILLIAMS, C. H.; BEWLEY, R. A. Price arbitrage between queensland cattle auctions. Australian Journal of Agricultural Economics, v. 37, n. 1, p. 33-55, April, 1993.

WILLIAMSON, J. A economia aberta e a economia mundial. Rio de Janeiro: Campus, 1989. p. 138-147.

ZINI Jr., A. A. A política cambial em discussão. Revista de Economia Política, v. 9, n. 1, p. 47-61, jan. 1989.

ZINI Jr., A. A. A taxa de câmbio e política cambial no Brasil. São Paulo: EDUSP, 1993.

ZUCKUN, M. H. G. P. et al. A agricultura e a política cambial brasileira. São Paulo: Instituto de Pesquisa Econômica, 1976. 138p. (Séries Monografia). 


\section{APÊNDICE}

Derivação matemática de dois casos especiais da condição Marshall-Lerner 
Partindo-se de uma situação inicial de equilíbrio, a condição MarshallLerner necessária e suficiente para que uma desvalorização cambial melhore o saldo comercial é:

$\left[\frac{E x \cdot(N x-1)}{E x+N x}+\frac{N m \cdot(E m+1)}{E m+N m}\right]>0$

em que:

$E x=$ elasticidade-preço da oferta de exportação;

$N x$ = elasticidade-preço da demanda de exportação;

$E m$ = elasticidade-preço da oferta de importação; e,

$N m$ = elasticidade-preço da demanda de importação.

Com as elasticidades-preço da demanda definidas de maneira que são, normalmente, positivos.

Partindo da expressão (1) pode-se derivar dois casos especiais da condição Marshall-Lerner.

\section{a) Modelo para país pequeno}

Assume-se que as elasticidades de demanda de exportação $(N x)$ e de oferta de importação $(E m)$ são infinitas.

Tomando o limite da expressão (1) com as elasticidades de demanda de exportação e oferta de importação tendendo para o infinito $(N x, E m \rightarrow \infty)$, temos:

$\lim _{N \times, E m \rightarrow \infty}\left[\frac{E x \cdot N x-E x}{E x+N x}+\frac{N m \cdot E m+N m}{E m+N m}\right]>0$ 
Percebe-se, facilmente, pela substituição de $N x$ e $E m$ na expressão acima, que o limite dessa expressão é indeterminado.

Para levantar a indeterminação do limite, dividimos o numerador e o denominador da primeira divisão por $N x$ e o da segunda divisão por $E m$, como segue:

$\lim _{N x, E m \rightarrow \infty}\left[\frac{\frac{E x \cdot N x}{N x}-\frac{E x}{N x}}{\frac{E x}{N x}+\frac{N x}{N x}}+\frac{\frac{N m \cdot E m}{E m}+\frac{N m}{E m}}{\frac{E m}{E m}+\frac{N m}{E m}}\right]>0$ ou $\lim _{N x, E m \rightarrow \infty}\left[\frac{E x-\frac{E x}{N x}}{\frac{E x}{N x}+1}+\frac{N m+\frac{N m}{E m}}{1+\frac{N m}{E m}}\right]>0$

Como $N x$ e $E m$ tendem ao infinito, temos que $\frac{E x}{N x}$ e $\frac{N m}{E m}$ tendem a zero. Logo, produzimos:

$(E x+N m)>0$

b) Caso em que as elasticidades de oferta de exportações e importações são infinitamente elásticas

Tomando o limite da expressão (1) com as elasticidades de oferta tendendo para o infinito $(E x, E m \rightarrow \infty)$, temos:

$\lim _{E x, E m \rightarrow \infty}\left[\frac{E x \cdot N x-E x}{E x+N x}+\frac{N m \cdot E m+N m}{E m+N m}\right]>0$

O limite dessa expressão com $E x$ e $E m$ tendendo para o infinito também é indeterminado. 
De forma análoga ao procedimento anterior, levantamos a indeterminação do limite dividindo o numerador e o denominador da primeira divisão por $E x$ e o da segunda divisão por Em, como segue:

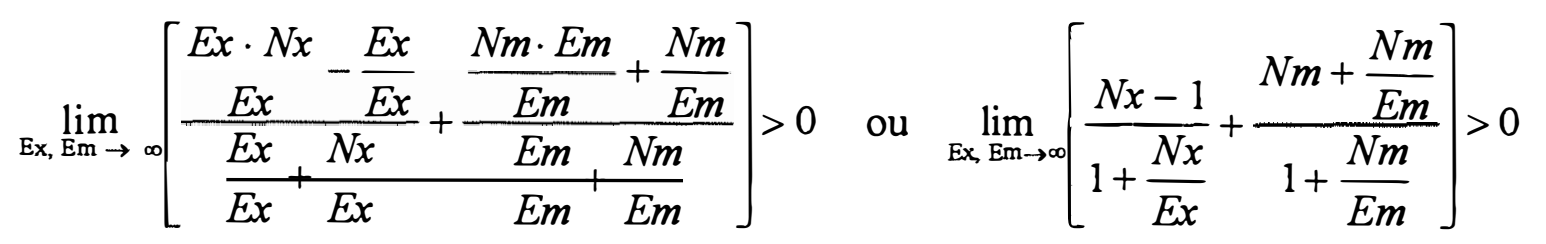

Como $E x$ e $E m$ tendem ao infinito, $\frac{N x}{E x}$ e $\frac{N m}{E m}$ tendem a zero. Logo, produzimos:

$$
(N x-1+N m)>0
$$

ou, equivalentemente, $(N x+N m)>1$ 